\title{
Spatial and temporal trends of the Stockholm Convention POPs in mothers' milk — a global review
}

\author{
Johan Fång • Elisabeth Nyberg • Ulrika Winnberg • Anders Bignert • Åke Bergman
}

Received: 7 October 2014 / Accepted: 4 January 2015 / Published online: 26 April 2015

(C) The Author(s) 2015. This article is published with open access at Springerlink.com

\begin{abstract}
Persistent organic pollutants (POPs) have been of environmental and health concern for more than half a century and have their own intergovernmental regulation through the Stockholm Convention, from 2001. One major concern is the nursing child's exposure to POPs, a concern that has led to a very large number of scientific studies on POPs in mothers' milk. The present review is a report on the assessment on worldwide spatial distributions of POPs and of their temporal trends. The data presented herein is a compilation based on scientific publications between 1995 and 2011. It is evident that the concentrations in mothers' milk depend on the use of pesticides and industrial chemicals defined as POPs. Polychlorinated biphenyls (PCBs) and "dioxins" are higher in the more industrialized areas, Europe and Northern America, whereas pesticides are higher in Africa and Asia and polybrominated diphenyl ethers (PBDEs) are reported in higher concentrations in the USA. POPs are consequently distributed to women in all parts of the world and are thus delivered to the nursing child. The review points out several major problems in the reporting of data, which are crucial to enable high quality comparisons. Even though the data set is large, the comparability is hampered by differences in reporting. In conclusion, much more detailed instructions are
\end{abstract}

Responsible editor: Hongwen Sun

$\mathrm{J}$. Fång $\cdot \mathrm{U}$. Winnberg $\cdot$ Å. Bergman

Department of Environmental Science and Analytical Chemistry,

Stockholm University, 10691 Stockholm, Sweden

J. Fång $(\bowtie) \cdot$ E. Nyberg $\cdot$ A. Bignert

Department of Environmental Research and Monitoring,

Swedish Museum of Natural History, P.O. Box 50007,

11418 Stockholm, Sweden

e-mail: fangsten@yahoo.se

Å. Bergman

Swedish Toxicology Sciences Research Center (Swetox), Forskargatan 20, 15136 Södertälje, Sweden needed for reporting POPs in mothers' milk. Temporal trend data for POPs in mothers' milk is scarce and is of interest when studying longer time series. The only two countries with long temporal trend studies are Japan and Sweden. In most cases, the trends show decreasing concentrations of POPs in mothers' milk. However, hexabromocyclododecane is showing increasing temporal concentration trends in both Japan and Sweden.

Keywords Breast milk · Persistent organic pollutants . Stockholm Convention $\cdot$ DDT $\cdot$ Dioxin $\cdot \mathrm{HCH} \cdot \mathrm{HCB}$. PBDE $\cdot$ HBCDD

\section{Introduction}

Mothers' milk is a source of nutrients, energy, and protection for the newborn child, and it carries essential elements from the mother to the child (Kramer and Kakuma 2012). Due to the lipophilic properties of a range of anthropogenic organic pollutants, ubiquitously distributed in human food and our environment, many of these chemicals are accumulated in mothers' milk. Accordingly, the nursing child is targeted by a vast number of undesirable pollutants (IPCS 2007; UNEP and WHO 2013). These pollutants are similar to those entering the fetus via the cord blood after transfer across the placental barrier (CDC 2013; Frederiksen et al. 2010), although there are differences in the presence of pollutants in the blood and in the mothers' milk. Due to the high chemical and metabolic stability and toxicity of some anthropogenic chemicals as well as their ability to spread globally, and bioaccumulate, 25 chemicals have been adopted under the Stockholm Convention (SCa), known as persistent organic pollutants (POPs). Among these listed POPs, polybrominated diphenyl ethers (PBDEs) are separated 
Table 1 Names and abbreviations of all POPs and two suggested POPs are presented, CAS numbers are given, as well as chemical structures or general structures. Some major review documents regarding the POPs are presented under "Review articles" (the column to the far right)

\begin{tabular}{|c|c|c|c|c|}
\hline Name & Abbreviation & CAS a & General structure & Review articles \\
\hline $\begin{array}{l}\text { 2,2-bis(4-chlorophenyl)-1.1.1- } \\
\text { trichloroethane }\end{array}$ & DDT & $50-29-3$ & & $\begin{array}{l}\text { IPCS (1989b; 2011), } \\
\text { Stemmler and } \\
\text { Lammel (2009) }\end{array}$ \\
\hline \multirow[t]{3}{*}{ 1,2,3,4,5,6-Hexachlorocyclohexane } & $\alpha-\mathbf{H C H}$ & $319-84-6$ & & $\begin{array}{l}\text { ATSDR (2005), } \\
\text { Vijgen et al. (2011) }\end{array}$ \\
\hline & $\beta-H C H$ & $319-85-7$ & & \\
\hline & $\begin{array}{l}\gamma \text {-HCH } \\
\text { (Lindane) }\end{array}$ & $58-89-9$ & 4 & \\
\hline Polychlorinated biphenyl & PCBs & $1336-36-3$ & & $\begin{array}{l}\text { ATSDR (2000), } \\
\text { CICAD (2003) }\end{array}$ \\
\hline Hexachlorobenzene & HCB & $118-74-1$ & & IPCS (1997) \\
\hline Polychlorinated dibenzodioxin & PCDDs & $\mathrm{N} / \mathrm{A}$ & & $\begin{array}{l}\text { IPCS (2002), Van } \\
\text { den Berg et al. (2006) }\end{array}$ \\
\hline Polychlorinated dibenzofuran & PCDFs & N/A & & $\begin{array}{l}\text { IPCS (2002), Van } \\
\text { den Berg et al. (2006) }\end{array}$ \\
\hline Dioxin like polychlorinated biphenyls & DL-PCBs & N/A & & $\begin{array}{l}\text { IPCS (2002), Van } \\
\text { den Berg et al. (2006) }\end{array}$ \\
\hline $\begin{array}{l}\text { CB-77; CB-126*; CB-156; CB-81; CB- } \\
\text { 105; CB-114; CB-118; CB-123; CB- } \\
\text { 157; CB-167; CB-169; CB-189 } \\
\text { * Structure given of CB-126 }\end{array}$ & & & & \\
\hline Polybrominated diphenyl ether & PBDEs & $\mathrm{N} / \mathrm{A}$ & & EFSA (2012) \\
\hline $\begin{array}{l}1,2,4,5,6,7,8,8 \text {-Octachloro- } \\
2,3,3 \mathrm{a}, 4,7,7 \mathrm{a}-\mathrm{h} \text { exahydro-4,7- } \\
\text { methanoindene }\end{array}$ & Chlordane & $12789-03-6$ & & $\operatorname{IPCS}(1984 a)$ \\
\hline $\begin{array}{l}\text { 1,4,5,6,7,8,8-heptachloro-3a,4,7,7a- } \\
\text { tetrahydro-4,7-Methano-1H-indene }\end{array}$ & Heptachlor & $76-44-8$ & & $\operatorname{IPCS}(1984 c)$ \\
\hline $\begin{array}{l}\text { (1aR,2R,2aS,3S,6R,6aR,7S,7aS)- } \\
\text { 3,4,5,6,9,9-hexachloro- } \\
\text { 1a,2,2a,3,6,6a,7,7a-octahydro-2,7:3,6- } \\
\text { dimethanonaphtho[2,3-b]oxirene }\end{array}$ & Dieldrin & $60-57-1$ & & $\operatorname{IPCS}(1989 a)$ \\
\hline
\end{tabular}


Table 1 (Continued)

\begin{tabular}{|c|c|c|c|c|}
\hline Name & Abbreviation & CAS a & General structure & Review articles \\
\hline 1,2,5,6,9,10-Hexabromocyclododecane & HBCDD & $3194-55-6$ & & EFSA (2011) \\
\hline $\begin{array}{l}1,1 \mathrm{a}, 2,2,3,3 \mathrm{a}, 4,5,5,5 \mathrm{a}, 5 \mathrm{~b}, 6- \\
\text { dodecachlorooctahydro-1,3,4-Metheno- } \\
1 H \text {-cyclobuta }[c d] \text { pentalene }\end{array}$ & MIREX & $2385-85-5$ & & ATSDR (1995) \\
\hline Perfluorooctanesulfonic acid & PFOS & $1763-23-1$ & & $\begin{array}{l}\text { Lindström et al. } \\
\text { (2011), Stock et al. } \\
(2009)\end{array}$ \\
\hline $\begin{array}{l}6,7,8,9,10,10 \text {-Hexachloro-1,5,5a,6,9,9a- } \\
\text { hexahydro- } 6,9 \text {-methano- } 2,4,3- \\
\text { benzodioxathiepine-3-oxide }\end{array}$ & Endosulfan & $115-29-7$ & & IPCS (1984b) \\
\hline $\begin{array}{l}\text { 1,2,3,4,10,10-Hexachloro- } 1,4,4 \mathrm{a}, 5,8,8 \mathrm{a}- \\
\text { hexahydro- } 1,4: 5,8 \text { - } \\
\text { dimethanonaphthalene }\end{array}$ & Aldrin & $309-00-2$ & & IPCS (1989a) \\
\hline Polychlorinated camphene & Toxaphene & $8001-35-2$ & $\mathrm{CH}_{2}$ & ATSDR (2010) \\
\hline 1,2,3,4,5-Pentachlorobenzene & PeCBz & $608-93-5$ & & \\
\hline $\begin{array}{l}\text { (1aR,2S,2aS,3S,6R,6aR,7R,7aS)- } \\
\text { 3,4,5,6,9,9-hexachloro- } \\
\text { 1a,2,2a,3,6,6a,7,7a-octahydro-2,7:3,6- } \\
\text { dimethanonaphtho[2,3-b]oxirene }\end{array}$ & Endrin & $72-20-8$ & & ATSDR (1996) \\
\hline Polybrominated biphenyl & PBBs & N/A & & EFSA (2010) \\
\hline $\begin{array}{l}\text { decachloropentacyclo }\left[5 \cdot 3 \cdot 0 \cdot 0^{2.6} \cdot 0^{3.9} \cdot 0^{4.8}\right] \\
\text { decan-5-one }\end{array}$ & $\begin{array}{l}\text { Chlordecone, } \\
\text { Kepone }\end{array}$ & $143-50-0$ & & ATSDR (1995) \\
\hline Short-chained chlorinated paraffins & $\operatorname{SCCPs}\left(\mathrm{C}_{10}-\mathrm{C}_{13}\right)$ & $\mathrm{N} / \mathrm{A}$ & & NICNAS (2004) \\
\hline
\end{tabular}


into tetra-/pentaBDEs and hexa-/heptaBDEs, which actually make the POPs to 24 different entries. Six other POPs are presently under discussion for inclusion among the legacy POPs $(\mathrm{SCb})$, and among these, short chain chlorinated paraffins (SCCPs) are included in the present review. The POPs reviewed herein are listed in Table 1.

The overarching toxicity of POPs is related to endocrine disruption (UNEP and WHO 2013) and/or listed as carcinogenic, mutagenic, or reprotoxic (CMRs). The toxicities of the POPs are extensively studied and will not be discussed in any detail here; instead, we prefer to refer to some of the most recent reviews on the different POPs listed in Table 1. Toxicological data for many of the POPs are often related to accidental exposures to humans or wildlife and considerable animal testing in toxicological laboratories. Some of the POPs show acute toxicity, like the "drins" (i.e., dieldrin, endrin, and aldrin). On the contrary, chronic effects have been observed for, e.g., DDT, and its transformation product dichlorodiphenyldichloroethylene (DDE), effects which were particularly emphasized in birds. The effects of many of the POPs on reproduction have been shown among wildlife species.

Accordingly, it is of interest to review the present exposure situation to POPs for nursing children worldwide, i.e., spatial exposure data as well as levels of POPs in mothers' milk over time. The objective of this review is to summarize the concentrations of POPs in mothers' milk during a delimited time period, 1995-2011. In addition, some recent data have been generated within the Swedish monitoring program and are included herein.

Analysis of some of the first identified POPs in mothers' milk was published in the 1960s (Norén and Westöö 1968) and then novel POPs were added to the list (Westöö and Norén 1978). Still, as shown herein, there is limited mothers' milk data for several of the POPs.

\section{Materials and methods}

Names, abbreviations, and (general) structures of the POPs applied in the present review are presented in Table 1, together with reviews discussing their toxicities/ecotoxicological effects.

Methods for data retrieval on POPs in mothers' milk

A literature search was performed using the database Web of Science and the following search terms were used: "Human Milk," "Breast Milk," "Mother's Milk," and "Mothers Milk," combined with the name of the substance of interest. All references found were compiled in one database and duplicates were removed.
Methods for inclusion of data

To reduce errors due to comparison of data from different sources and to avoid presenting a historical overview, the following limits were set for inclusion in the study:

- The study must be a scientific peer-reviewed paper published 1995-2011.

- Studies must report and quantify any of the POPs listed in Table 1, in at least six subjects (donors). In the case of pooled samples, a pool should contain a minimum of six donors.

- Information about place and year of sampling are required.

- Inclusion of a time series requires a minimum of five reported data points and is only included if the report/paper includes the original values of the time series.

Other sources of data

Data from the Swedish Environmental Monitoring Program are included herein (http://www.imm.ki.se/Datavard/ aBiologiska_mätdata__organiska_ämnen), as well as time series data from Fång et al. (2013).

Substance summary tables

Concentration data are presented in the substance summary tables (Tables 2, 3, 4, 5, 6, 7, 8, 9, 10, 11, 12, and 13) in the following manner:

- One reported concentration from one sample location is represented by a single value, e.g., "5."

- Two reported concentrations from one location are represented by two values separated by a semicolon, e.g., "3; 5."

- Three or more reported concentrations from one sample location are represented by giving the range, e.g., "3-5."

- If a study reports data from more than one sampling location, all are included, e.g., by presenting, "Sweden 5" and "Norway 4."

- In the case of a time series, i.e., more than one sample from one location, only the most recent value is included in the summary table.

- A "sum value" is only given if more than one of the components of the "sum value" are reported.

- If "sum values" are reported, the reported value is used. If not reported, the sum is calculated if possible.

- If data from the same samples are presented in several studies, only the latest study is included in the table.

- Three-letter country codes according to ISO 3166-1 alpha3 are used in the figures, herein. 
Spatial distribution diagrams

If mean or median values are given for different sampling locations within the same country or subgroups (e.g., age, primiparae versus multiparae), a weighted mean or median value is calculated based on the number of individuals in each group: for example, reported mean concentrations of 2,3 , and $5 \mathrm{ng} / \mathrm{g}$ fat of BDE-47, based on 10, 10, and 20 samples (total of 40 samples) from cities $\mathrm{X}, \mathrm{Y}$ and $\mathrm{Z}$ in Sweden, respectively. The weighted mean value for study A will thus be a bar at $3.75 \mathrm{ng} / \mathrm{g}$ fat example given below.

$$
\begin{aligned}
& \frac{2 \mathrm{ng} / \mathrm{g} \times 10}{40}+\frac{3 \mathrm{ng} / \mathrm{g} \times 10}{40}+\frac{5 \mathrm{ng} / \mathrm{g} \times 20}{40} \\
& =3.75 \mathrm{ng} / \mathrm{g}
\end{aligned}
$$

Equation 1. Example of how the weighted means were calculated.

In the spatial distribution diagrams, e.g., Fig. 3, the studies are sorted by rising concentrations within each region.

Methods applied for statistical reports

To test for significant log-linear trends, log-linear regression analyses were performed for the entire investigated time period and for the most recent 10 years using the annual arithmetic mean values. In cases where the regression line had a poor fit, a 3-point running mean smoother was checked for statistical significance in comparison with the regression through an ANOVA (Nicholson et al. 1998). Potential outliers in the temporal trends were detected using a method described by Hoaglin and Welsch (1978). The suspected outliers are merely indicated in the figures and were included in the statistical calculations. Values below level of quantification (LOQ) were replaced by $\mathrm{LOQ} / 2$ prior to the statistical analyses. Power analysis was also carried out. The power was fixed to $80 \%$ and the minimum possible trend to be detected during a monitoring period of 10 years at a significant level of $5 \%$ was estimated. A significance level of $5 \%$ was used for all tests.

\section{Results and discussion}

A total of 253 scientific articles on POPs in mothers' milk were identified on the basis of the applied methodology (cf. above). Several of the articles included data on more than one of the POPs. The diagram (Fig. 1) visualizes the number of reported concentrations of the corresponding POP that were available for this review. The results are presented in this review in descending order, starting from the POPs that are most well researched in relation to occurrence and concentrations in mothers' milk, worldwide, i.e., going from DDT to SCCP and chlordecone (Fig. 1).

Looking into the distribution of the scientific articles published on POPs in mothers' milk in the chosen time period, it is clear that most of the studies originate from China, Japan, North America, and Western Europe (Fig. 2). However, publications are scattered throughout the globe making a spatial trend review possible. The results of the spatial distribution and concentrations of POPs are presented under the sections "DDT and DDTrelated compounds" to "SCCPs," including tables and figures when applicable. Temporal trend data on POPs in mothers' milk are scarce but available data are reported herein under the sections "DDT and DDT related compounds" to "PFOS." Some novel data are included for recent exposure assessments performed on mothers' milk from Sweden.

All concentration data given in Tables 2, 3, 4, 5, 6, 7, 8, 9, $10,11,12$, and 13 are presented on a weight basis (ng or pg) per gram extracted fat, with the exception of perfluorooctane sulfonate (PFOS) which is presented in $\mathrm{pg} / \mathrm{mL}$.

It is of importance to consider that a reported concentration might not be generally applicable to a country as a whole, for instance, samples might originate from a farming area where pesticides have been in use. This could be more important to consider for countries with large diversity, either geographically and/or cultural, i.e., rural versus urban life styles. In smaller, more homogenous countries such as Sweden, POP concentrations have been found to be quite uniform, independent of geographical distribution (Glynn et al. 2011).

\section{DDT and DDT-related compounds}

A very large total number of reports are dealing with DDT and related compounds in mothers' milk. Related compounds are 2,4'-DDT and the transformation products 4,4'-DDE, 4,4'DDD, 2,4'-DDE, and 2,4'-DDD. The data shown in Table 2 refer only to the three individual compounds 4,4'-DDT, 4,4'DDE, and 4,4'-DDD as well as $\sum$ DDT. However, the $\sum$ DDT may consist of some very different sums, sometimes including only the three main $4,4^{\prime}$-substituted DDTs mentioned but occasionally also including $2,4^{\prime}$-substituted DDTs. This makes the sum data less reliable for comparisons. However, we have still chosen to include sum data to visualize the larger data set, but avoiding the confusion with further differentiated data. Concentration data on 4,4'-DDT, 4,4'-DDE, and 4,4'-DDD are presented in detail in Table 2, subsectioned into four geographically large areas, i.e., Africa; Asia, Australia, and the Pacific region; Europe; and The Americas. Some of the results on DDT and related compounds in mothers' milk are highlighted below.

Table 2 includes calculated ratio values of 4,4'-DDT/4,4'DDE based on reported mean or median concentrations of the 
Fig. 1 Number of reported observations (total 744) in 253 scientific papers of the legacy POPs in mothers' milk, from 1995 to 2011, subdivided on the POPs reported herein and presented in order of abundance of studies. Eighty percent of all studies are linked to seven of the POPs, DDT-chlordane. Note that a scientific paper may include observations of more than POP

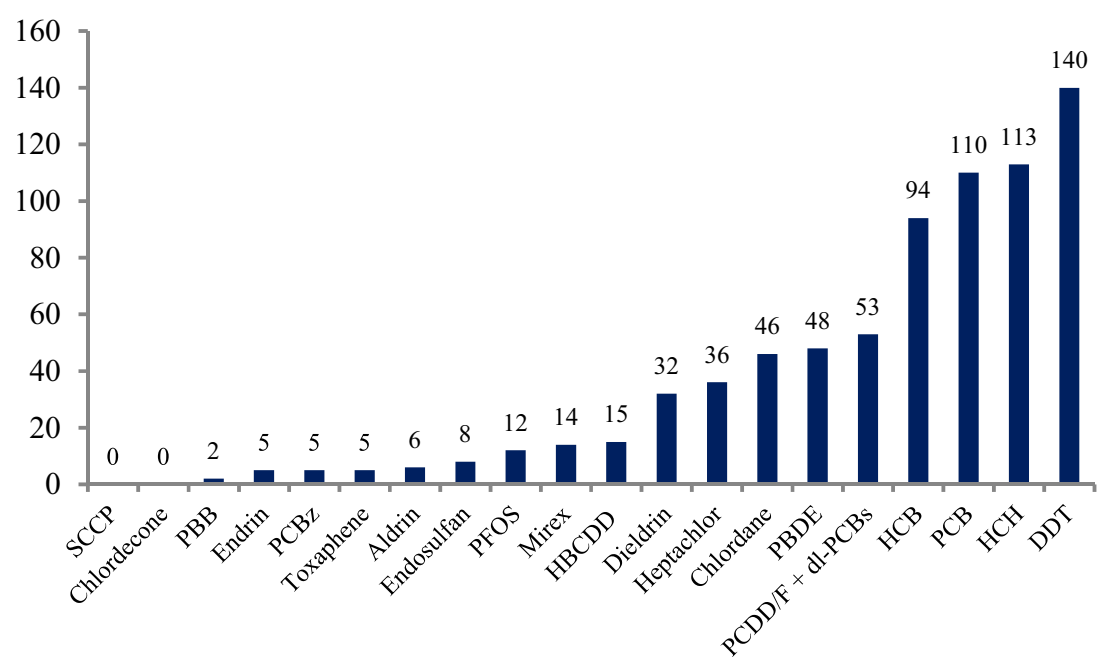

two compounds and gives an indication for recent discharges of DDT (with ratio values of 0.5 and above) or more historical use (ratios below 0.2 ) of this pesticide. Figure 3 displays the 4 , $4^{\prime}$-DDT and 4,4'-DDE concentrations as reported throughout the world.

\section{Africa}

Concentrations of 4,4'-DDE are the highest among the three individual DDT compounds reported in Table 2, although the $4,4^{\prime}$-DDT/4,4'-DDE ratio indicates similar levels between the two major constituents in mothers' milk. The highest concentrations of $4,4^{\prime}$-DDT and $4,4^{\prime}$-DDE are reported from Zimbabwe (Chikuni et al. 1997) and South Africa (Okonkwo et al. 2008; Sereda et al. 2009). Still, a few studies indicate low concentrations of DDTs in mothers' milk. It is particularly clear that African mothers have high concentrations of 4,4'-DDT compared to most other samples from other regions. This is of course implying present or recent use of DDT for spraying, potentially indoors (Channa et al. 2012).

\section{Asia, Australia, and the Pacific region}

Reports from Asia, Australia, and the Pacific Region indicate that certain mothers have been highly exposed to both $4,4^{\prime}$ DDT and 4,4'-DDE (Nair et al. 1996; Nasir et al. 1998; Stuetz et al. 2001; Wong et al. 2002), while overall levels are above the common European concentrations, but below the concentrations reported for milk from African mothers (Table 2 and Fig. 3). The data indicate primarily old releases of DDT based on the low 4,4'-DDT/4,4'-DDE ratio, although there are exceptions (e.g., Nair et al. 1996; Nasir et al. 1998; Stuetz et al.
Fig. 2 Global distribution of exposure assessment studies of POPs in mothers' milk, up to year 2011. The circles are placed at the site of the capital city for each country, and the sizes of the circles visualize the abundance of studies from the countries on which this review is built. Black circle $=1$ study, green circle $=2$ 5 studies, blue circle $=6-10$ studies, red circle $=11-15$ studies, and pink circle $>15$ studies

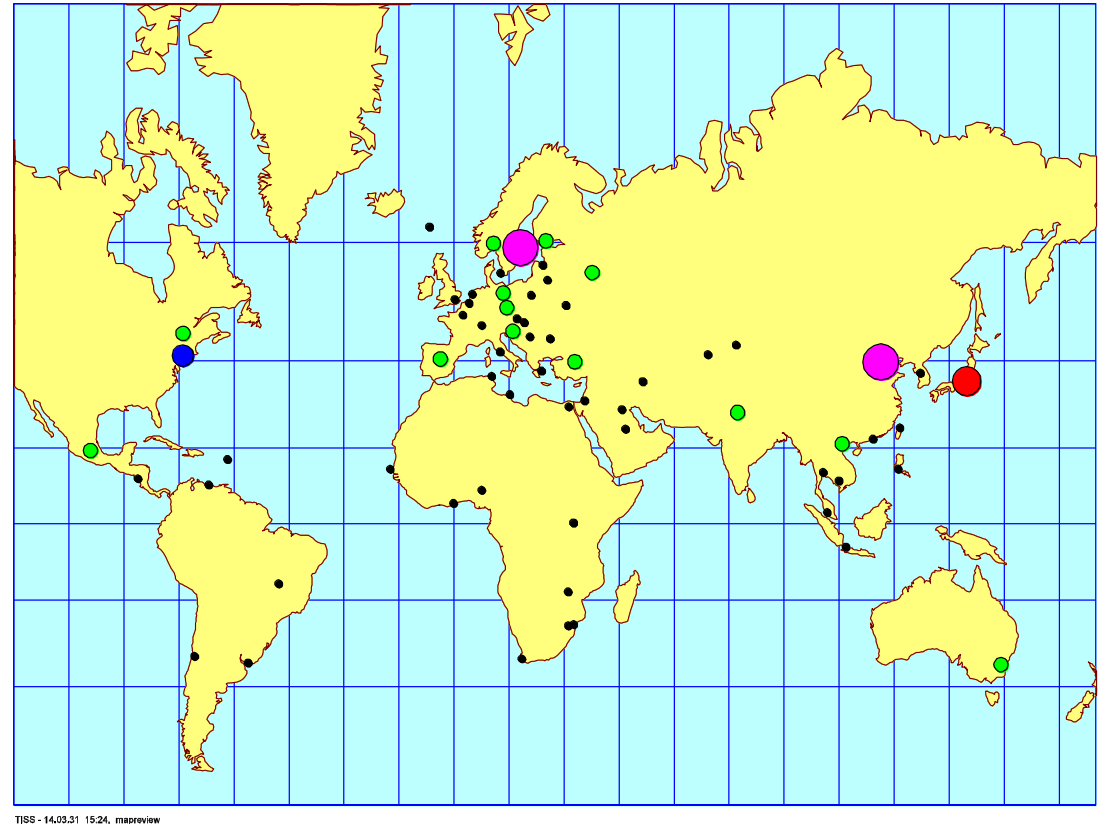




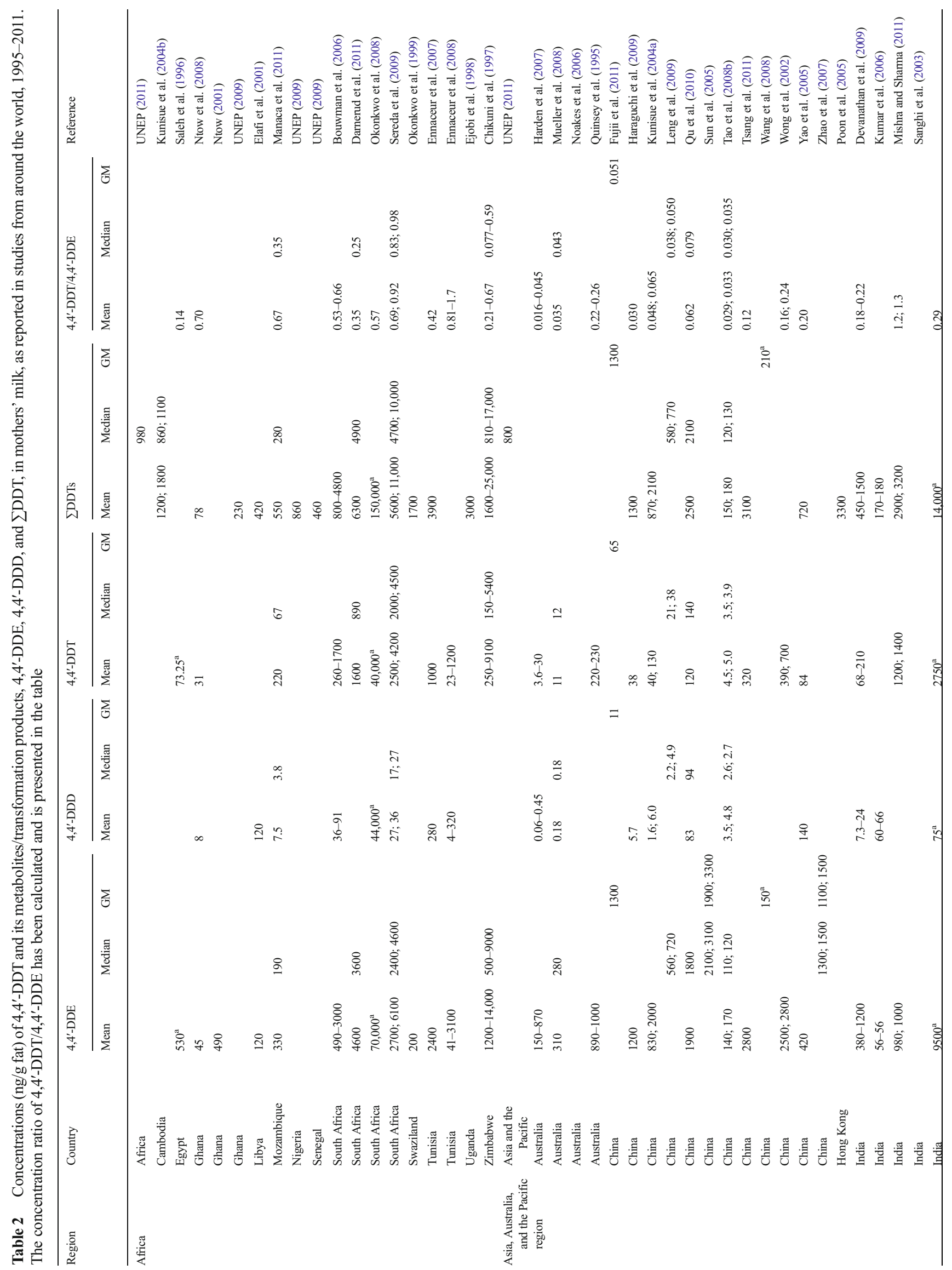




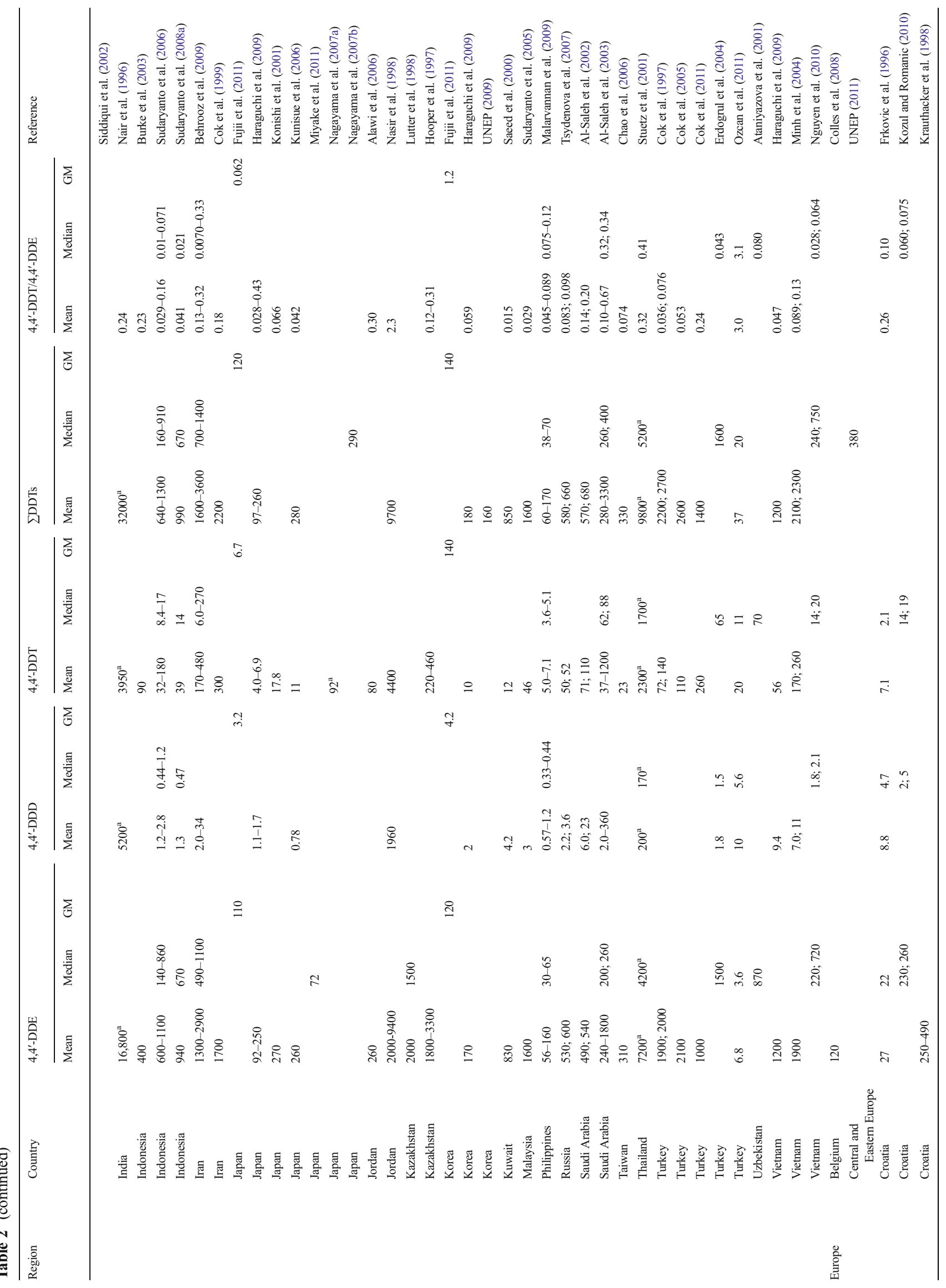




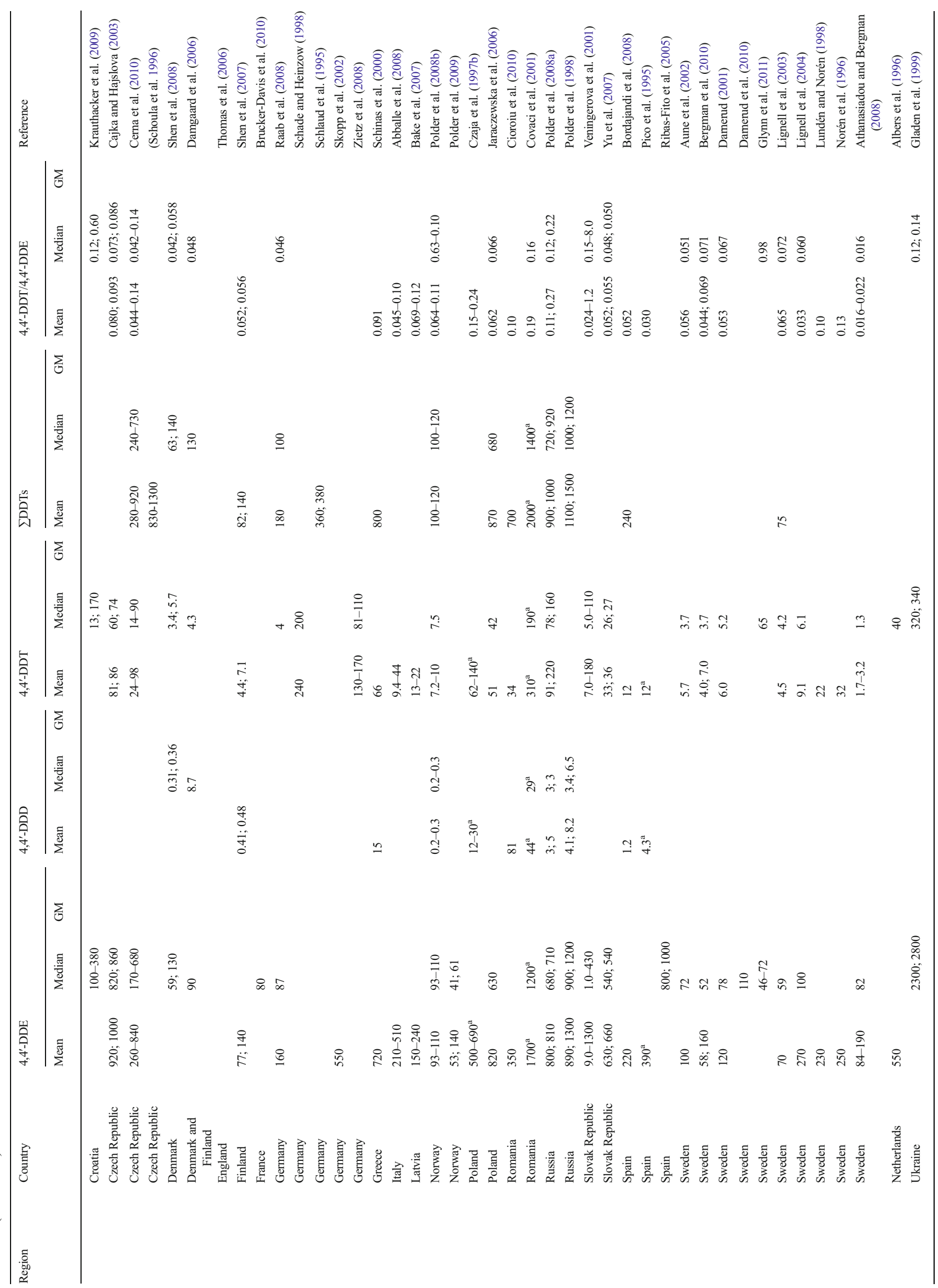




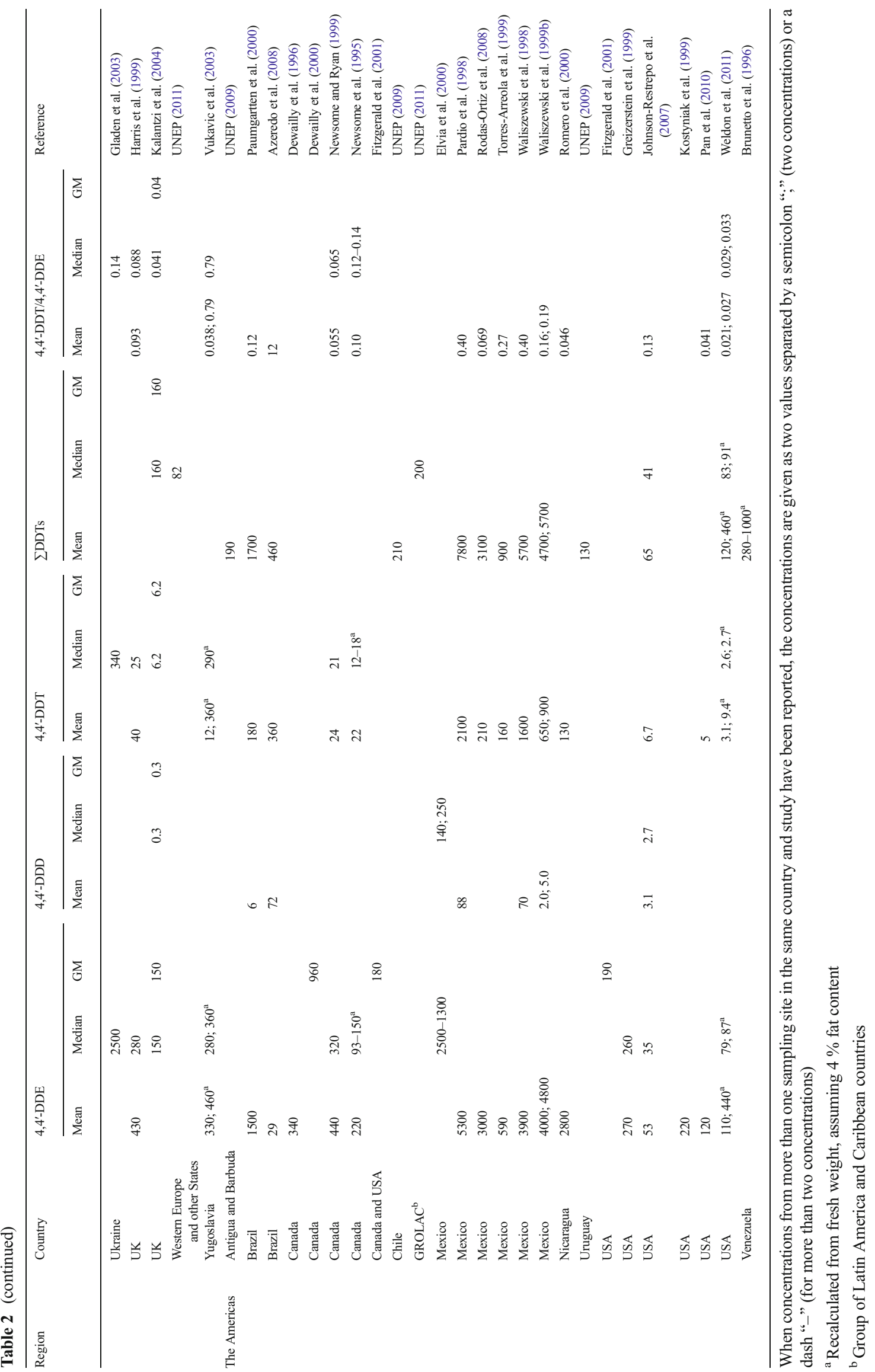


2001; Wong et al. 2002). Accordingly, direct exposure to DDT cannot be excluded.

\section{Europe}

The majority of studies on DDT in mothers' milk are originating from Europe. The levels are in the lowest end (e.g., $20-250 \mathrm{ng} / \mathrm{g}$ fat of 4,4'-DDE) of all studies reviewed except for studies on DDTs in milk from the Eastern part of Europe, $250-2800 \mathrm{ng} / \mathrm{g}$ fat, as shown in Table 2. The higher concentrations in Eastern Europe is also followed by higher $4,4^{\prime}$-DDT/4, $4^{\prime}$-DDE ratios indicating more recent use or unintentional release of DDT. However, the ratio is generally low indicating successful elimination of this POP from use in the society. The DDT and related compounds still present in mothers' milk are a mirror of intake via food. Some high exposure levels to DDT among Eastern European citizens, as determined by analysis of blood, are supporting the higher levels in mothers' milk from countries in this part of Europe (Hovander et al. 2006).

\section{The Americas}

Low concentrations of DDTs are reported from Canada and the USA, while Mexico in Central America (Table 2) reported levels that are similarly high as in Africa and some Asian countries. It is notable that in the countries from which the mothers' milk contain the highest concentrations of DDTs, there is a more recent input of DDT (Fig. 3), which is confirmed by higher $4,4^{\prime}$-DDT/4,4'-DDE ratios, $0.12-0.4$ (Table 2). A Brazilian study is reporting the highest ratio among all studies reviewed, i.e., 12 (Azeredo et al. 2008), indicating the present use of DDT. However, the actual concentration of $\sum$ DDTs is lower than many other studies.

PCBs

Polychlorinated biphenyls (PCBs) reported as CB-153, sum of the six indicator CBs (CB-28, CB-52, CB-101, CB-138, CB-153, and CB-180, only if the concentrations of all six were reported), or the estimated total sum of PCB ( $\sum$ PCB, the method of estimating the sum may vary between studies) in all 116 studies were tabulated (Table 3). Dioxin-like PCBs are not reported here but instead discussed together with the dioxins and furans ("PCDDs, PCDFs, and DL-PCBs"). Since PCBs are showing decreasing trends after the bans came into effect, studies from different time periods (1995-2011) may not be altogether comparable (Fig. 4).

\section{Africa}

Five studies of PCBs from Africa were found in the database search. CB-153 ranges from approximately 2 to $120 \mathrm{ng} / \mathrm{g}$ fat in South Africa (Darnerud et al. 2011) and Tunisia (Ennaceur et al. 2008), respectively. The reported $\sum$ PCB ranges from about 3 to $750 \mathrm{ng} / \mathrm{g}$ fat in Zimbabwe (Chikuni et al. 1997) and Tunisia (Ennaceur et al. 2008), respectively.

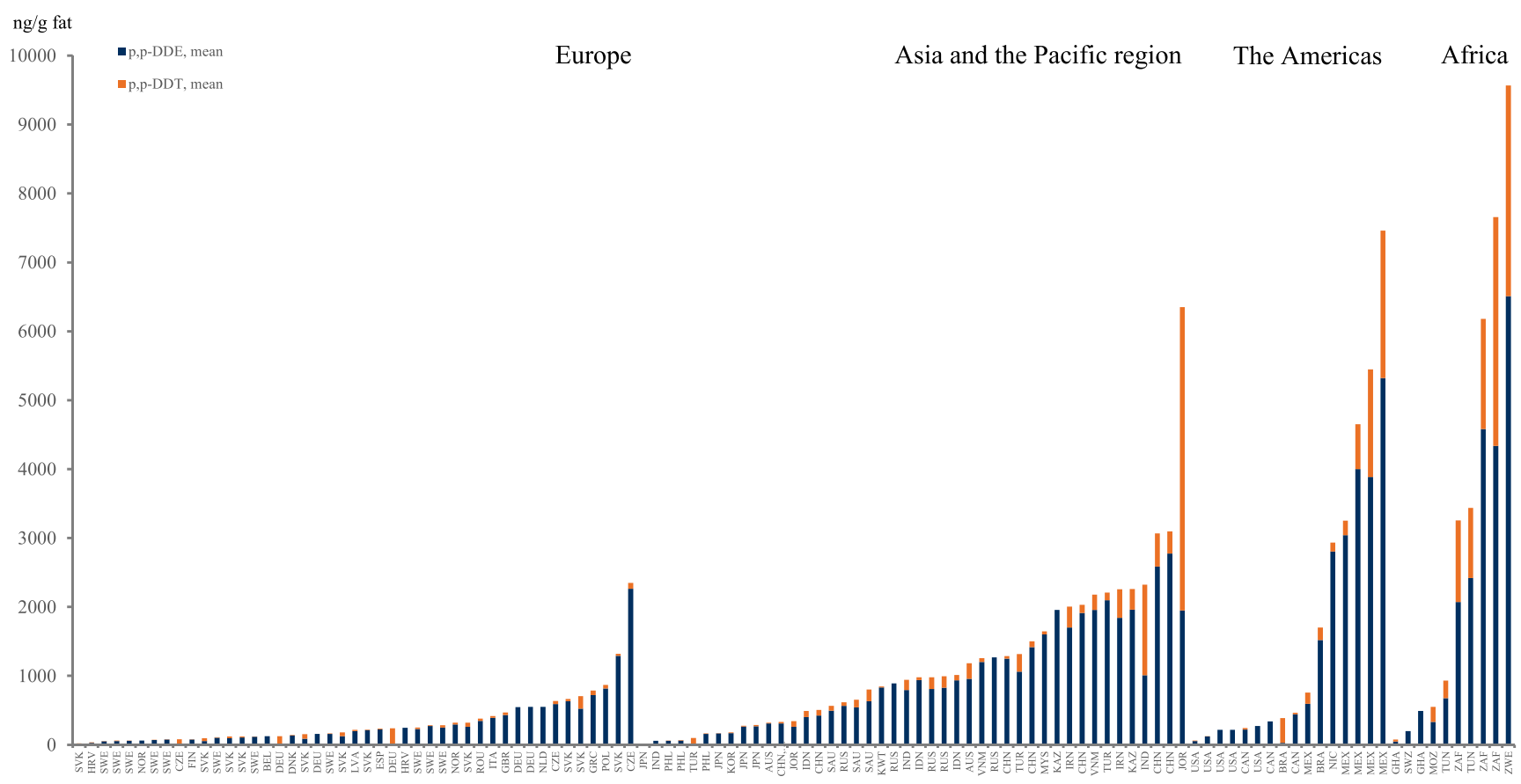

Fig. 3 The sum of p,p-DDE and p,p-DDT reported worldwide is given in the figure, where contribution p,p-DDE is represented in dark blue and the contribution $\mathrm{p}, \mathrm{p}$-DDT is represented in orange 
Table 3 Concentrations (ng/g fat) of CB-153, $\sum 6$ indicator PCBs, and $\sum$ PCBs, in mothers' milk, as reported in studies from around the world, 1995-2011

\begin{tabular}{|c|c|c|c|c|c|c|c|c|c|}
\hline \multirow[t]{2}{*}{ Region } & \multirow[t]{2}{*}{ Country } & \multicolumn{2}{|l|}{ CB-153 } & \multicolumn{2}{|c|}{$\sum 6$ indicator $\mathrm{PCBs}^{\mathrm{a}}$} & \multicolumn{3}{|l|}{$\sum \mathrm{PCB}$} & \multirow[t]{2}{*}{ Reference } \\
\hline & & Mean & Median & Mean & Median & Mean & Median & GM & \\
\hline \multirow[t]{5}{*}{ Africa } & Africa & & & & 31 & & & & UNEP (2011) \\
\hline & Ghana & $6.4-22$ & $5.4-19$ & & & $30-82$ & $26-72$ & & Asante et al. (2011) \\
\hline & South Africa & 2.6 & 2 & & & 10 & 8.4 & & Darnerud et al. (2011) \\
\hline & Tunisia & $18-120$ & & $95-660$ & & $110-750$ & & & Ennaceur et al. (2008) \\
\hline & Zimbabwe & & & & & $2.8-60$ & & & Chikuni et al. (1997) \\
\hline \multirow{36}{*}{$\begin{array}{l}\text { Asia, Australia, } \\
\text { and the Pacific } \\
\text { region }\end{array}$} & Asia and the Pacific & & & & 15 & & & & UNEP (2011) \\
\hline & Australia & & & & & $160-480$ & & & Quinsey et al. (1995) \\
\hline & Cambodia & & & & & $20-29$ & $13-24$ & & Kunisue et al. (2004a) \\
\hline & China & & & & & $28-42$ & & & Kunisue et al. (2004a) \\
\hline & China & & & & & 74 & & & Poon et al. (2005) \\
\hline & China & 14 & & & & 49 & & & Tsang et al. (2011) \\
\hline & China & & & & & $33 ; 42$ & & & Wong et al. (2002) \\
\hline & China & & & & & 9.5 & & & Xing et al. (2009) \\
\hline & China & $0.49-16$ & & $2.4-29$ & & & & & Zhang et al. (2011) \\
\hline & China & & 13.28 & & & & 210 & 210 & Zhao et al. (2007) \\
\hline & India & & & & & $23-40$ & & & Devanathan et al. (2009) \\
\hline & Indonesia & & & & & $21-33$ & $17-27$ & & Sudaryanto et al. (2006) \\
\hline & Iran & $200-250$ & $46-150$ & $990-1900$ & $130-1000$ & & & & Behrooz et al. (2009) \\
\hline & Japan & & & & & 120 & 110 & & Kawashiro et al. (2008) \\
\hline & Japan & & & & & 200 & & & Konishi et al. (2001) \\
\hline & Japan & & & & & 120 & & & Kunisue et al. (2006) \\
\hline & Japan & & & & & 120 & 100 & & Nakamura et al. (2008) \\
\hline & Japan & & & & & & 110 & & Nagayama et al. (2007a) \\
\hline & Japan & 19 & 18 & 39 & 36 & 73 & 67 & & Todaka et al. (2011) \\
\hline & Jordan & 25 & & & & 42 & & & Alawi et al. (2006) \\
\hline & Kazakhstan & & & $100-430$ & & $220-820$ & & & Hooper et al. (1997) \\
\hline & Kazakhstan & & & $100-350$ & & 410 & & & Lutter et al. (1998) \\
\hline & Kazakhstan & 65 & 50 & 180 & 130 & 370 & 290 & & She et al. (1998) \\
\hline & Malaysia & & & & & $14 ; 80$ & & & Sudaryanto et al. (2005) \\
\hline & Russia & & & & & $160-240$ & & & Tsydenova et al. (2007) \\
\hline & Taiwan & & & 55 & & & 54 & & Wang et al. (2004) \\
\hline & Philippines & & & & & $50-70$ & $40-60$ & & Malarvannan et al. (2009) \\
\hline & Turkey & 11 & & 26 & & 27 & & & Cok et al. (2011) \\
\hline & Turkey & 110 & & 190 & & 210 & & & Cok et al. (2003) \\
\hline & Turkey & $3.4-11$ & & $11-19$ & & $18-36$ & & & Cok et al. (2009) \\
\hline & Turkey & $8.5^{\mathrm{b}}$ & $8.2^{\mathrm{b}}$ & & & $27^{\mathrm{b}}$ & $28^{\mathrm{b}}$ & & Erdogrul et al. (2004) \\
\hline & Turkey & 12 & 6.5 & 100 & 69 & & & & Ozcan et al. (2011) \\
\hline & Vietnam & $11-43$ & & & & $56-150$ & & & Haraguchi et al. (2009) \\
\hline & Vietnam & & & & & $74 ; 79$ & & & Minh et al. (2004) \\
\hline & Vietnam & & $5.7 ; 8.2$ & & & $33 ; 46$ & $24 ; 33$ & & Tue et al. (2010) \\
\hline & Vietnam & & $4.7 ; 8.1$ & & $14 ; 22$ & & $33 ; 47$ & & Nguyen et al. (2010) \\
\hline \multirow[t]{4}{*}{ Europe } & Belgium & 43 & & 97 & & 110 & & & Colles et al. (2008) \\
\hline & $\begin{array}{l}\text { Central and } \\
\text { Eastern Europe }\end{array}$ & & & & 47 & & & & UNEP (2011) \\
\hline & Croatia & & $39 ; 42$ & & $110 ; 110$ & & $120 ; 130$ & & Kozul and Romanic (2010) \\
\hline & Croatia & & & & & & 210 & & Krauthacker et al. (1998) \\
\hline
\end{tabular}


Table 3 (continued)

\begin{tabular}{|c|c|c|c|c|c|c|c|c|c|}
\hline \multirow[t]{2}{*}{ Region } & \multirow[t]{2}{*}{ Country } & \multicolumn{2}{|l|}{ CB-153 } & \multicolumn{2}{|c|}{$\sum 6$ indicator $\mathrm{PCBs}^{\mathrm{a}}$} & \multicolumn{3}{|l|}{$\sum \mathrm{PCB}$} & \multirow[t]{2}{*}{ Reference } \\
\hline & & Mean & Median & Mean & Median & Mean & Median & GM & \\
\hline & Croatia & & 29 & & & & 120 & & Krauthacker et al. (2009) \\
\hline & Croatia & & 10 & & 110 & & 140 & & $\begin{array}{l}\text { Zubcic and Krauthacker } \\
\text { (2004) }\end{array}$ \\
\hline & Czech Republic & $220 ; 420$ & & $530 ; 1100$ & & $620 ; 1200$ & & & Bencko et al. (1998) \\
\hline & Czech Republic & $260 ; 300$ & $220 ; 260$ & & & $940 ; 1100$ & $780 ; 900$ & & Cajka and Hajslova (2003) \\
\hline & Czech Republic & $93-900$ & $98-650$ & $300-2000$ & $310-1500$ & $490-4900$ & $480-3400$ & & Cerna et al. (2010) \\
\hline & Czech Republic & $270-480$ & & & & $860-1100$ & & & Schoula et al. (1996) \\
\hline & Finland & $88 ; 110$ & & & & $350 ; 440$ & & & Vartiainen et al. (1997) \\
\hline & France & & 59 & & & & 170 & & Brucker-Davis et al. (2010) \\
\hline & Germany & & & & & 550 & 500 & & Schade and Heinzow (1998) \\
\hline & Germany & & & & & $540 ; 1300$ & & & Schlaud et al. (1995) \\
\hline & Germany & 140 & & & & 310 & & & Skopp et al. (2002) \\
\hline & Germany & 90 & & & & 210 & & & Wittsiepe et al. (2007) \\
\hline & Germany & & & & & 200 & 180 & & Zietz et al. (2008) \\
\hline & Italy & 54 & & 120 & & 200 & & & Alivernini et al. (2011) \\
\hline & Italy & 110 & 110 & & & 280 & 280 & & Riva et al. (2004) \\
\hline & Italy & $22-38$ & & $50-92$ & & $82-130$ & & & Ulaszewska et al. (2011) \\
\hline & Latvia & $16-24$ & & & & $110-170$ & & & Bake et al. (2007) \\
\hline & Lithuania & $130-160$ & & $290-360$ & & $400-480$ & & & Becher et al. (1995) \\
\hline & Netherlands & & 77 & & 240 & & 270 & & Albers et al. (1996) \\
\hline & Netherlands & $120-140$ & & $300-350$ & & $360-410$ & & & van den Berg et al. (1995) \\
\hline & Norway & $130-140$ & & $270 ; 300$ & & $330-380$ & & & Becher et al. (1995) \\
\hline & Norway & & & & & & 99 & & Eggesbo et al. (2006) \\
\hline & Norway & $44-53$ & 52 & $100-120$ & $100-120$ & $160-180$ & $160-200$ & & Polder et al. (2008b) \\
\hline & Norway & & & & & $110 ; 120$ & $100 ; 110$ & & Polder et al. (2009) \\
\hline & Poland & & & & & $190-550^{\mathrm{b}}$ & & & Czaja et al. (1997a) \\
\hline & Poland & 40 & 35 & & & 150 & 130 & & Jaraczewska et al. (2006) \\
\hline & Poland & & & & & $170-350$ & & & Pietrzak-Fiecko et al. (2005) \\
\hline & Poland & $30 ; 38$ & & $56 ; 77$ & & $82 ; 97$ & & & Skrbic et al. (2010) \\
\hline & Romania & $58^{\mathrm{b}}$ & $37^{\mathrm{b}}$ & & & 9.7 & 6.5 & & Covaci et al. (2001) \\
\hline & Russia & $120 ; 130$ & $110 ; 120$ & $30-230$ & $20-210$ & $300-350$ & $290 ; 330$ & & Polder et al. (1998) \\
\hline & Russia & $50 ; 90$ & $50 ; 50$ & $120 ; 200$ & $100 ; 180$ & $190 ; 350$ & $180 ; 320$ & & Polder et al. (2008a) \\
\hline & Serbia & $26^{\mathrm{b}}$ & $11^{\mathrm{b}}$ & $76^{\mathrm{b}}$ & $27^{\mathrm{b}}$ & $81^{\mathrm{b}}$ & $31^{\mathrm{b}}$ & & Vukavic et al. (2008) \\
\hline & Slovak Republic & $230-480$ & & $540-1200$ & & $590-1300$ & & & Petrik et al. (2001) \\
\hline & Slovak Republic & $200 ; 200$ & $180 ; 180$ & & & $600 ; 650$ & $500 ; 540$ & & Yu et al. (2007) \\
\hline & Spain & & & & & 280 & & & Schuhmacher et al. (2009) \\
\hline & Sweden & $42-70$ & 51 & $87-140$ & 100 & $120-180$ & 140 & & $\begin{array}{l}\text { Athanasiadou and } \\
\text { Bergman (2008) }\end{array}$ \\
\hline & Sweden & 100 & & & & 240 & & & Atuma et al. (1998) \\
\hline & Sweden & 51 & 48 & & & 140 & 130 & & Aune et al. (2002) \\
\hline & Sweden & $29 ; 30$ & 27 & & & $99 ; 100$ & 98 & & Bergman et al. (2010) \\
\hline & Sweden & 56 & 55 & 110 & 110 & 148 & 144 & & Darnerud (2001) \\
\hline & Sweden & & 64 & & & & & & Darnerud et al. (2010) \\
\hline & Sweden & 74 & 69 & 150 & 136 & 170 & 160 & & Glynn et al. (2001) \\
\hline & Sweden & & $31-48$ & & & & $80-120$ & & Glynn et al. (2011) \\
\hline & Sweden & 61 & & & & 190 & & & Guvenius et al. (2003) \\
\hline
\end{tabular}


Table 3 (continued)

\begin{tabular}{|c|c|c|c|c|c|c|c|c|c|}
\hline \multirow[t]{2}{*}{ Region } & \multirow[t]{2}{*}{ Country } & \multicolumn{2}{|l|}{ CB-153 } & \multicolumn{2}{|c|}{$\sum 6$ indicator $\mathrm{PCBs}^{\mathrm{a}}$} & \multicolumn{3}{|l|}{$\sum \mathrm{PCB}$} & \multirow[t]{2}{*}{ Reference } \\
\hline & & Mean & Median & Mean & Median & Mean & Median & GM & \\
\hline & Sweden & 47 & 43 & & & 120 & 110 & & Lignell et al. (2003) \\
\hline & Sweden & 62 & 57 & & & 150 & 140 & & Lignell et al. (2004) \\
\hline & Sweden & 58 & 52 & & & 140 & 120 & & Lignell et al. (2009b) \\
\hline & Sweden & 58 & & & & 110 & & & Lignell et al. (2011) \\
\hline & Sweden & 96 & & 200 & & 380 & & & Lundén and Norén (1998) \\
\hline & Sweden & 96 & & & & 410 & & & Norén et al. (1996) \\
\hline & Switzerland & 36 & 28 & & & 290 & 240 & & $\begin{array}{l}\text { Zehringer and Herrmann } \\
\text { (2001) }\end{array}$ \\
\hline & Ukraine & & & & & & 600 & & Gladen et al. (2003) \\
\hline & Ukraine & & & & & & $490 ; 680$ & & Gladen et al. (1999) \\
\hline & UK & & 49 & & & & 180 & 150 & Kalantzi et al. (2004) \\
\hline & $\begin{array}{l}\text { Western Europe } \\
\text { and other States }\end{array}$ & & & & 79 & & & & UNEP (2011) \\
\hline & Former Yugoslavia & & & & & $11 ; 20$ & $4.9 ; 8.2$ & & Vukavic et al. (2003) \\
\hline \multirow[t]{14}{*}{ The Americas } & Brazil & 37 & & & & 150 & & & Paumgartten et al. (2000) \\
\hline & Canada & 54 & & & & 130 & & & Dewailly et al. (1996) \\
\hline & Canada & & & & & & & 620 & Dewailly et al. (2000) \\
\hline & Canada & 38 & 33.4 & & & 240 & 210 & & Newsome et al. (1995) \\
\hline & Canada & & & & & 250 & 240 & & Newsome and Ryan (1999) \\
\hline & Canada and USA & 50 & & & & 220 & & & Fitzgerald et al. (1998) \\
\hline & GROLAC $^{c}$ & & & & 28 & & & & UNEP (2011) \\
\hline & Mexico & 110 & & & & 1500 & & & Rodas-Ortiz et al. (2008) \\
\hline & USA & 33 & & & & 120 & & & Fitzgerald et al. (1998) \\
\hline & USA & 69 & 65 & & & 300 & 280 & & Greizerstein et al. (1999) \\
\hline & USA & & & $57^{\mathrm{d}}$ & & 270 & & & Kostyniak et al. (1999) \\
\hline & USA & 17 & & & & & 77 & & Pan et al. (2010) \\
\hline & USA & & & & & 91 & & & Park et al. (2011) \\
\hline & USA & $1.5 ; 9.0^{\mathrm{b}}$ & $1.1 ; 6.0^{\mathrm{b}}$ & & & $22 ; 29^{\mathrm{b}}$ & $19 ; 20^{\mathrm{b}}$ & & Weldon et al. (2011) \\
\hline
\end{tabular}

When concentrations from more than one sampling site in the same country and study have been reported, the concentrations are given as two values separated by a semicolon ";" (two concentrations) or a dash "-" (for more than two concentrations)

${ }^{a}$ Sum of CB-28, CB-52, CB-101, CB-138, CB-153, and CB-180

${ }^{\mathrm{b}}$ Recalculated from fresh weight, assuming $4 \%$ fat content

${ }^{\mathrm{c}}$ Group of Latin America and Caribbean countries

${ }^{\mathrm{d}}$ Reported as the sum of CB-105, CB-132, and CB-153

\section{Asia, Australia, and the Pacific region}

No less than 36 studies were found from this region and the majority report estimated $\sum$ PCB. The lowest concentrations are from China (Kunisue et al. 2004a; Xing et al. 2009), India (Devanathan et al. 2009), Indonesia (Sudaryanto et al. 2006), and Cambodia (Kunisue et al. 2004a). Higher concentrations of $\sum$ PCB were reported from Australia, $160-480 \mathrm{ng} / \mathrm{g}$ fat (Quinsey et al. 1995); Japan, 120-200 ng/g fat (Kawashiro et al. 2008; Kunisue et al. 2006; Nagayama et al. 2007a; Nakamura et al. 2008); Kazakhstan, 220-820 ng/g fat
(Hooper et al. 1997; Lutter et al. 1998; She et al. 1998); and Russia, 160-240 ng/g fat (Tsydenova et al. 2007). The lowest concentrations of CB-153, $0.5 \mathrm{ng} / \mathrm{g}$ fat, were reported from China (Zhang et al. 2011) and the highest in Iran, over $200 \mathrm{ng} /$ $\mathrm{g}$ fat (Behrooz et al. 2009).

\section{Europe}

Over $50 \%$ of the included studies came from Europe. The lowest concentrations of CB-153 in Europe, lower than $50 \mathrm{ng} /$ $\mathrm{g}$ fat, came from Belgium (Colles et al. 2008), Italy 

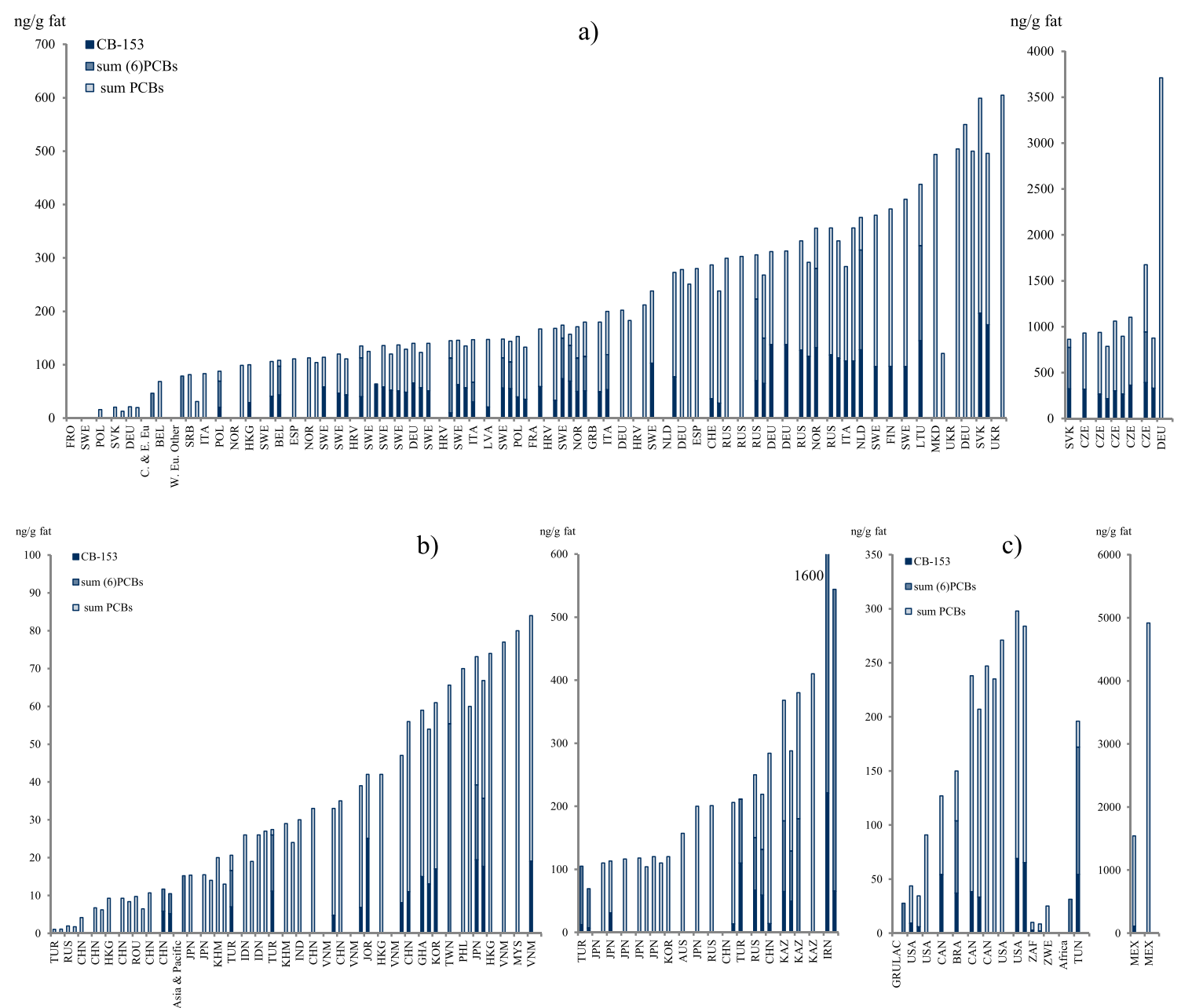

Fig. 4 a-c Graphical presentation of PCB concentrations in mothers' milk from countries worldwide

(Ulaszewska et al. 2011), Latvia (Bake et al. 2007), Norway (Polder et al. 2008b), Poland (Jaraczewska et al. 2006), and Sweden (Lignell et al. 2003). The highest concentrations (more than $300 \mathrm{ng} / \mathrm{g}$ fat) were reported from the Czech Republic (Bencko et al. 1998; Cerna et al. 2010; Schoula et al. 1996) and Slovak Republic (Petrik et al. 2001). This is also true for the estimated $\sum$ PCB, when reported. Concentrations $>1000 \mathrm{ng} / \mathrm{g}$ fat are reported from the Czech Republic (Bencko et al. 1998; Cerna et al. 2010; Schoula et al. 1996), Germany (Schlaud et al. 1995), and the Slovak Republic (Petrik et al. 2001). Although the ban of PCB that was introduced stepwise during the 1970s and 1980s has led to significantly lowered concentrations in the environment, leakage due to inappropriate handling of waste material or from, e.g., building material, large capacitors, and hydraulic systems, still in use or stored at dumping sites, can still be expected and can thus cause elevated concentrations in mothers' milk from highly industrialized countries.

\section{The Americas}

The concentrations of CB-153 reported from most of the 14 studies from the Americas were fairly low to moderate, around or below $50 \mathrm{ng} / \mathrm{g}$ fat: Brazil (Paumgartten et al. 2000), Canada (Dewailly et al. 1996; Newsome et al. 1995), and the USA (Fitzgerald et al. 1998; Pan et al. 2010). The highest concentration of CB-153, $110 \mathrm{ng} / \mathrm{g}$ fat (Rodas-Ortiz et al. 2008), as well as of the estimated $\sum$ PCB, $1500 \mathrm{ng} / \mathrm{g}$ fat (Rodas-Ortiz et al. 2008), was reported from Mexico.

\section{$\mathrm{HCB}$ and $\mathrm{HCHs}$}

Mothers' milk concentrations of hexachlorobenzene (HCB) and the three more common hexachlorocyclohexane $(\mathrm{HCH})$ isomers, $\alpha-\mathrm{HCH}, \beta-\mathrm{HCH}$, and $\gamma-\mathrm{HCH}$, are presented in Table 4, as well as the less commonly reported levels of $\delta$ HCH. $\alpha-\mathrm{HCH}, \beta-\mathrm{HCH}$, and $\gamma-\mathrm{HCH}$ represent the $\mathrm{HCHs}$ present in the "old" technical-grade $\mathrm{HCH}$ pesticide, while the 


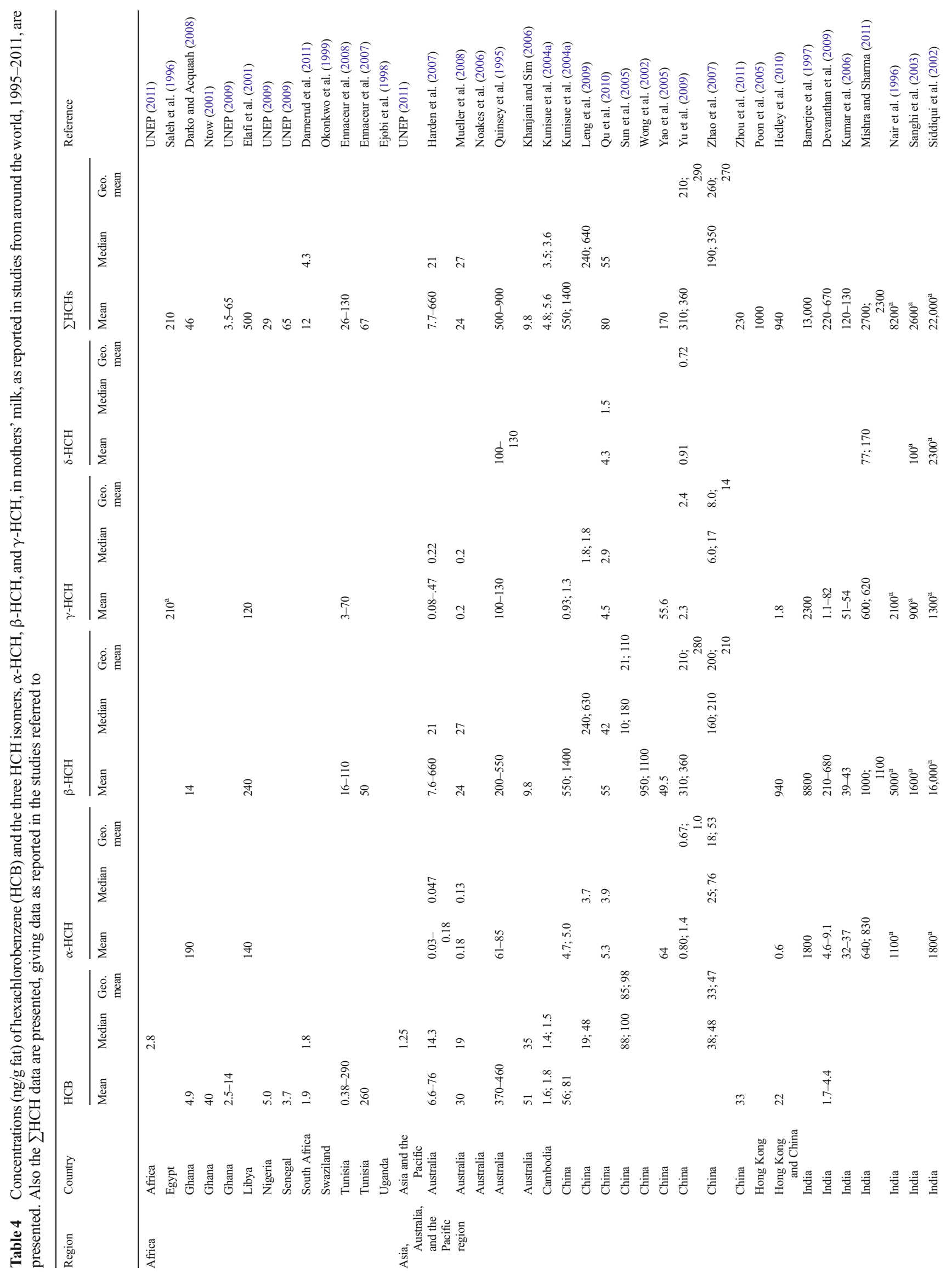




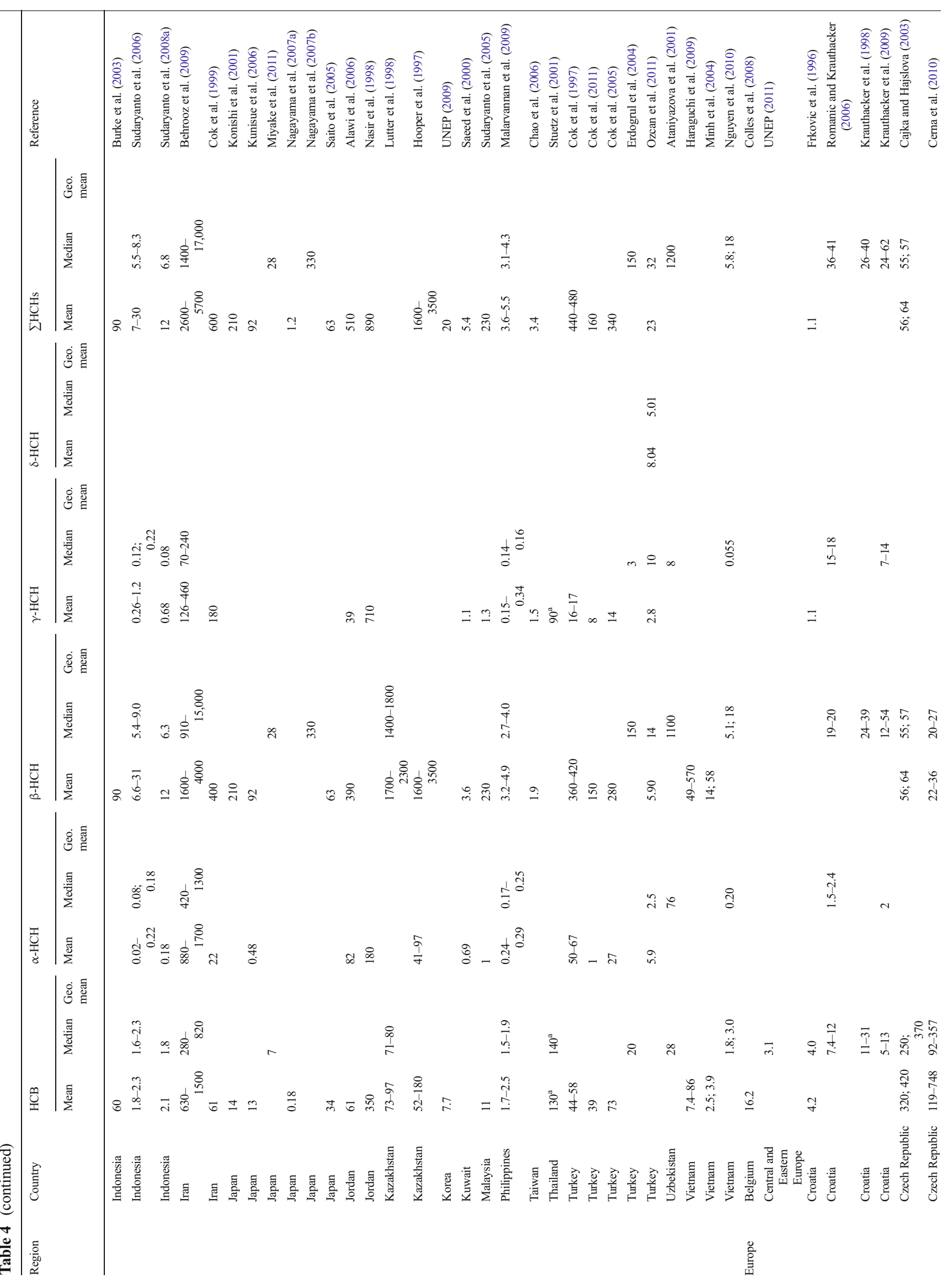




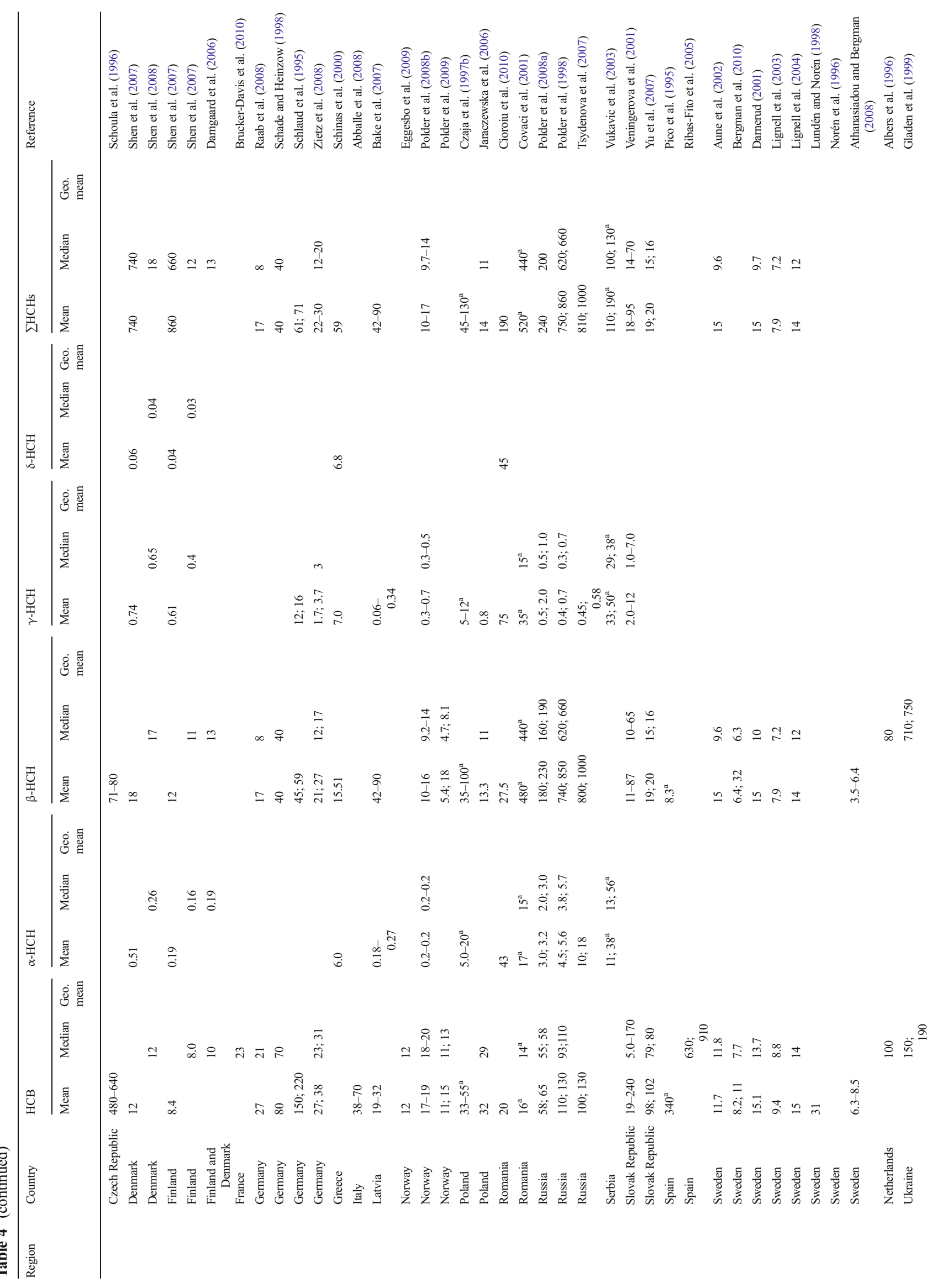




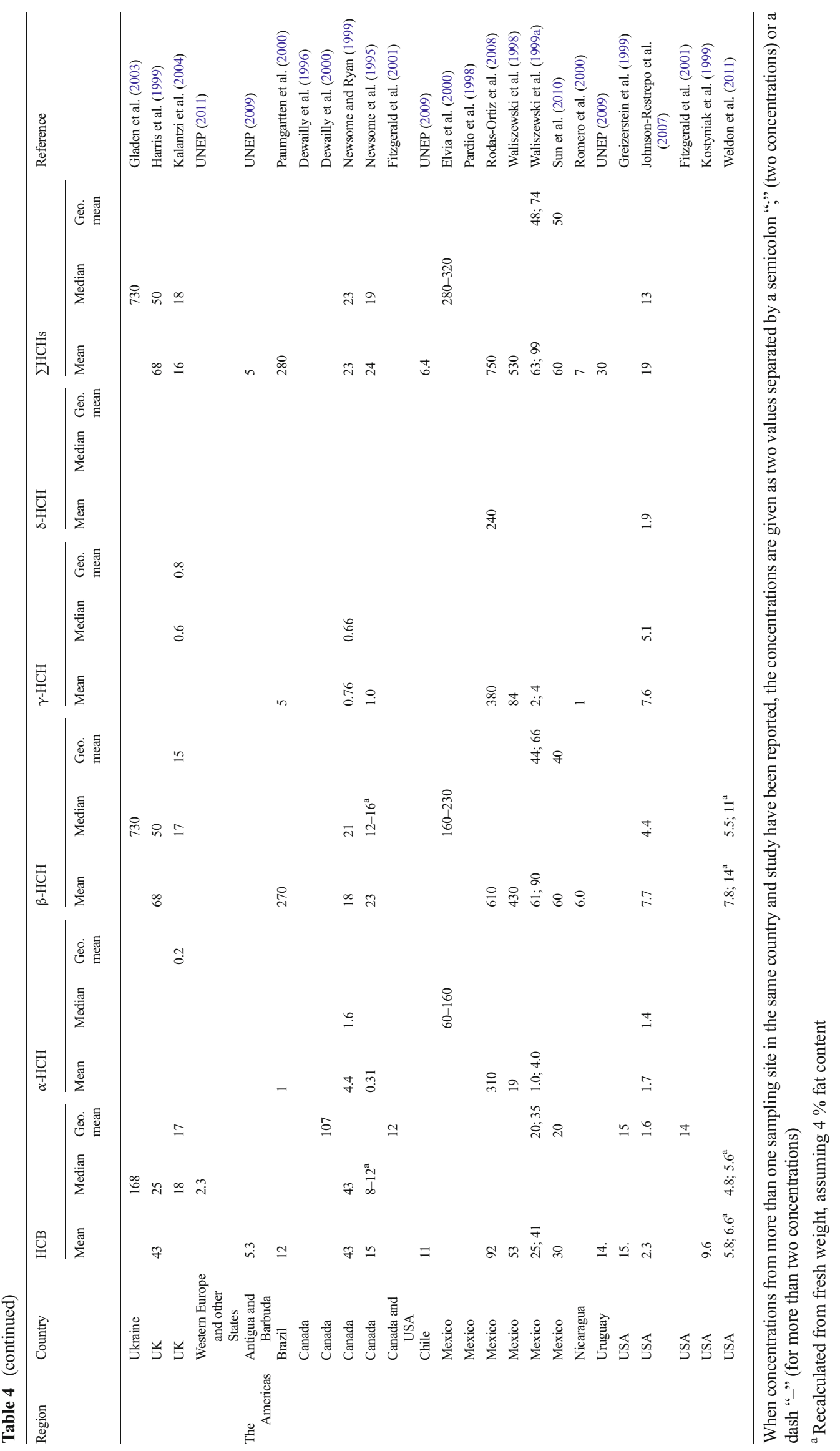


commonly used pesticide, lindane, corresponds to $\gamma-\mathrm{HCH}$. All the $\mathrm{HCH}$ isomers are related to pesticide use, while $\mathrm{HCB}$ has both a pesticide history and is also an abundant by-product from industrial activities and poorly controlled incineration/ backyard burning. The pattern of $\mathrm{HCH}$ in the world is highly influenced by recent use of $\mathrm{HCH}$ as a pesticide. It is notable that the $\beta-\mathrm{HCH}$ isomer is the most abundant of the $\mathrm{HCH}$ isomers in mothers' milk even though this compound is related to the historical $\mathrm{HCH}$ pesticide use and not to lindane $(\gamma-\mathrm{HCH})$. However, the half-life of $\gamma-\mathrm{HCH}$ is much shorter in humans and wildlife than the half-life of $\beta-\mathrm{HCH}$, and the observations confirm the higher persistency and lower reactivity of the $\beta-\mathrm{HCH}$ isomer compared to the others.

The data for $\mathrm{HCB}$ and the $\mathrm{HCHs}$ are dominated by studies of mothers' milk from Asia and Europe (Table 4) and are reported in 94 and 113 scientific reports worldwide, respectively (Figs. 5 and 6).
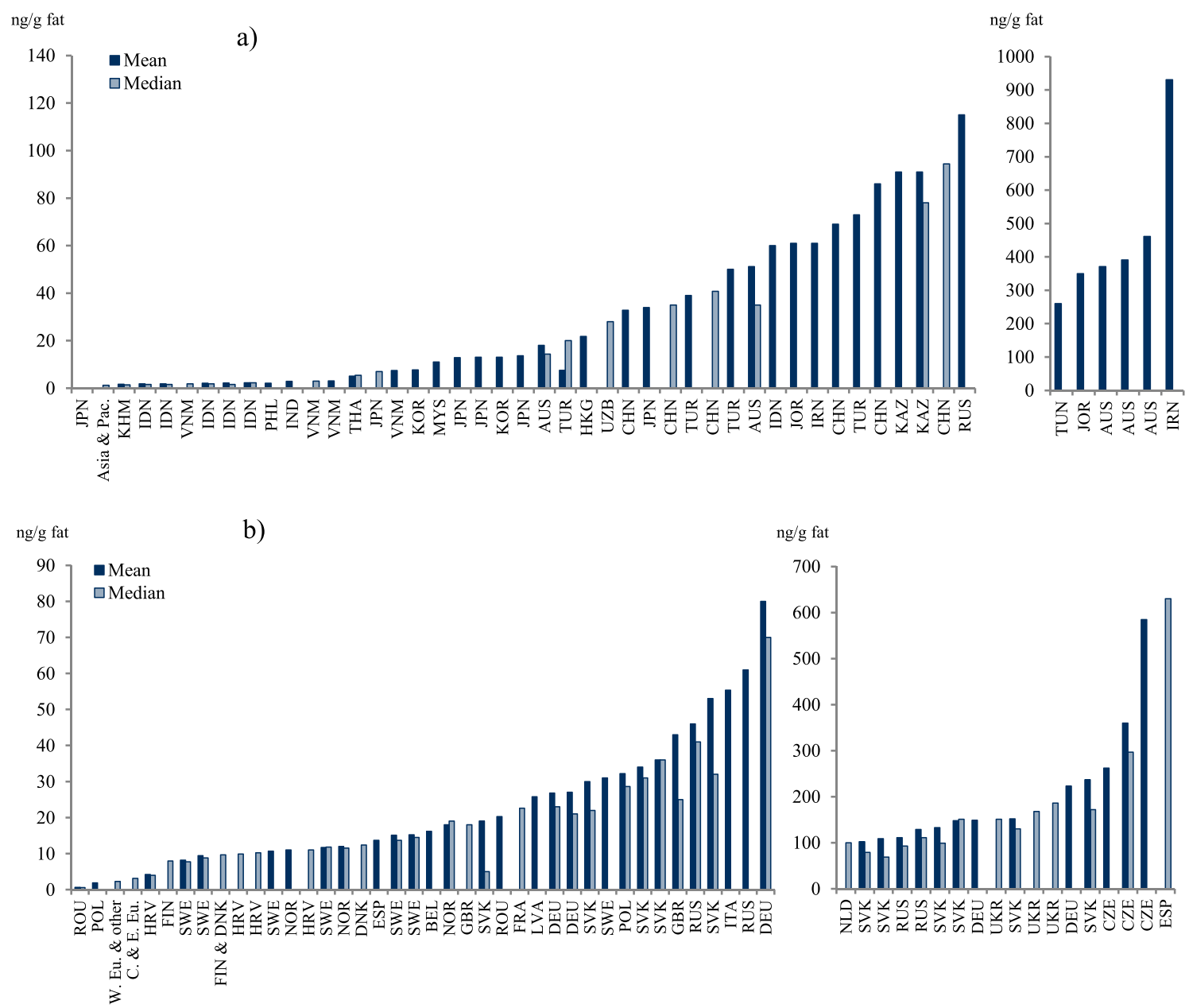

$\mathrm{ng} / \mathrm{g}$ fat

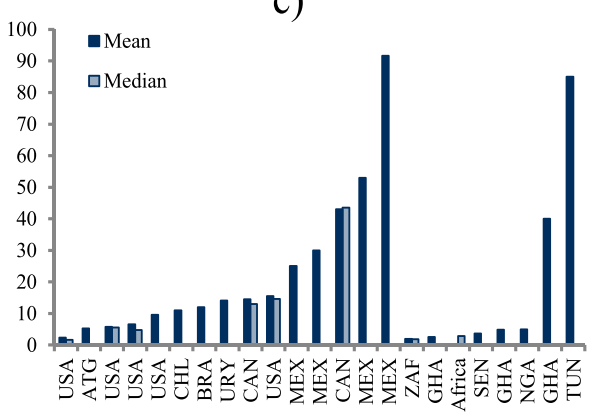

Fig. 5 a-c Graphical presentation of HCB concentrations in mothers' milk from countries worldwide 

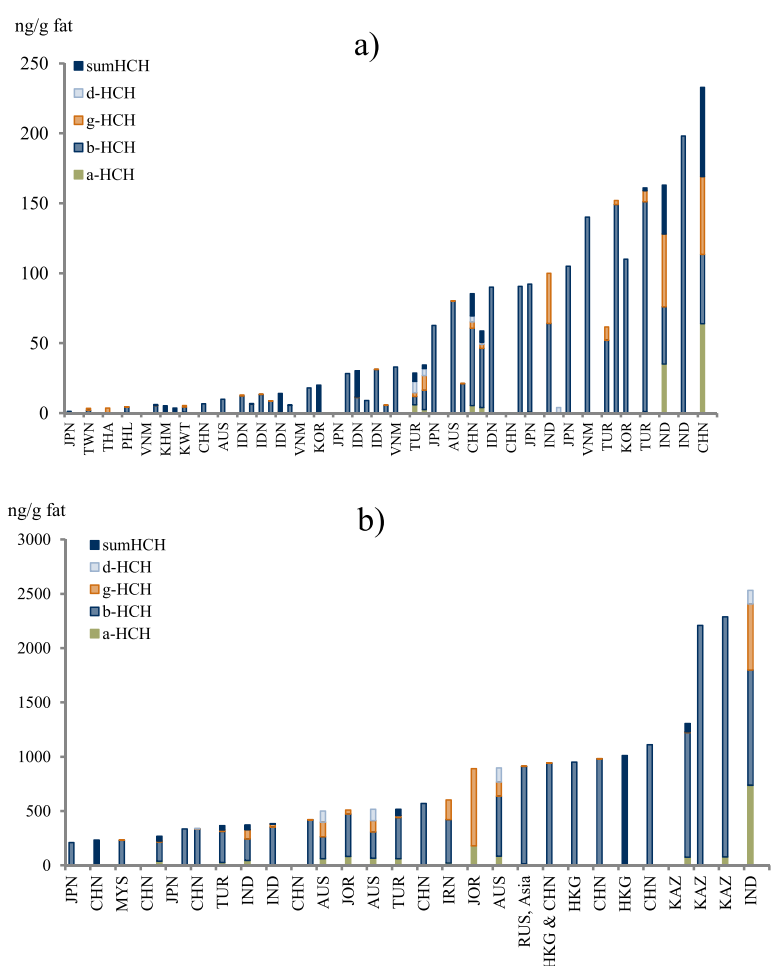
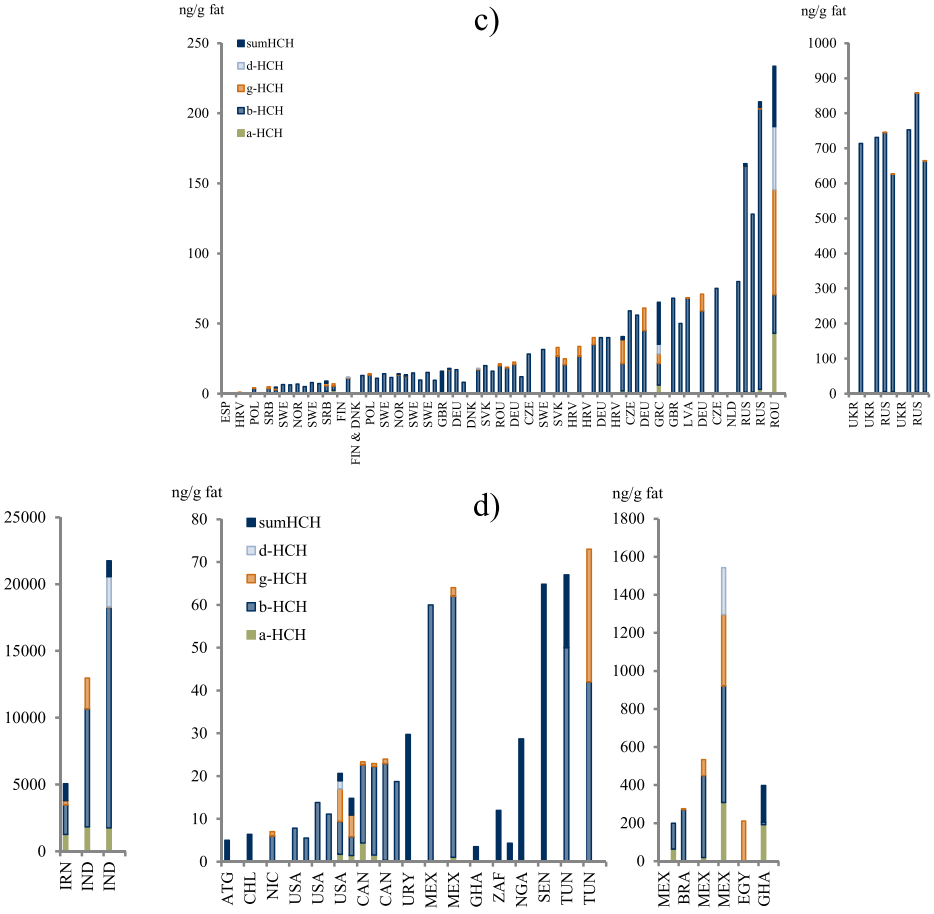

Fig. 6 a-d Graphical presentation of HCH concentrations in mothers' milk from countries worldwide. Note that "RUS, Asia" refers to samples from a location in the Asian part of the Russian Federation

\section{Africa}

Most reported HCB concentrations from African countries range from about 2 to $5 \mathrm{ng} / \mathrm{g}$ fat, on either mean or median basis. Somewhat higher levels are reported in Ghananese mothers' milk, 2.5-40 ng/g fat (Darko and Acquaah 2008; Ntow 2001; UNEP 2009). The highest concentrations are reported from Tunisia, mean concentration of $0.4-290 \mathrm{ng} / \mathrm{g}$ fat (Ennaceur et al. 2007, 2008).

In general, one could consider the $\mathrm{\Sigma HCH}$ levels in African mothers' milk to be on the lower end on a global scale and comparable to concentrations reported from the Americas. There are quite few studies from Africa reporting levels of $\sum \mathrm{HCH}$ in mothers' milk. Most of the studies report mean concentrations of approximately $10-100 \mathrm{ng} / \mathrm{g}$ fat (Table 4), the exceptions being one study from Ghana (Saleh et al. 1996) and one study from Libya (Elafi et al. 2001), reporting concentrations of 210 and $500 \mathrm{ng} / \mathrm{g}$ fat, respectively.

\section{Asia, Australia, and the Pacific region}

A few countries have reported HCB mean concentrations below $10 \mathrm{ng} / \mathrm{g}$ fat: Cambodia (Kunisue et al. 2004a), India (Devanathan et al. 2009), Korea (UNEP 2009), and the Philippines (Malarvannan et al. 2009). However, the majority of countries have reported mean values in the range
$10-100 \mathrm{ng} / \mathrm{g}$ fat (Table 4). In the higher end of reported $\mathrm{HCB}$, concentrations from the region include Australian levels between 370 and $460 \mathrm{ng} / \mathrm{g}$ fat (Behrooz et al. 2009; Quinsey et al. 1995), with levels up to $1500 \mathrm{ng} / \mathrm{g}$ fat, as well as Kazakhstan (Hooper et al. 1997) and Thailand (Stuetz et al. 2001), reporting concentrations above $100 \mathrm{ng} / \mathrm{g}$ fat (Table 4).

The reported levels of $\mathrm{HCHs}$, both individual isomers as well as $\mathrm{EHCH}$, are the highest in Asia, Australia, and the Pacific region, compared to the rest of the world, although there are a few studies reporting comparatively low mean concentrations, i.e., below $10 \mathrm{ng} / \mathrm{g}$ fat: Cambodia (Kunisue et al. 2004a), Kuwait (Saeed et al. 2000), the Philippines (Malarvannan et al. 2009), and Taiwan (Chao et al. 2006) but also studies from Japan (Nagayama et al. 2007a) and Australia (Khanjani and Sim 2006; Kunisue et al. 2004a). On the contrary, other studies from Japan and Australia report higher concentrations (Table 4). The majority of studies from Asia, Australia, and the Pacific region report $\sum \mathrm{HCH}$ concentrations in the range of hundreds of nanogram per gram fat, but a large number report concentrations in the range of thousands of nanogram per gram fat (Table 4). In India, there is a high $\mathrm{HCH}$ contamination according to the mothers' milk concentrations, which range from 120 to $22,000 \mathrm{ng} / \mathrm{g}$ fat $\mathrm{\Sigma HCH}$, with several studies reporting values of thousands of nanogram per gram fat (Table 4). The highest concentrations of the $\mathrm{HCH}$ isomers in mothers' milk have been reported from 
India with means of $1800,16,000,1300$, and $2300 \mathrm{ng} / \mathrm{g}$ fat for $\alpha-\mathrm{HCH}, \beta-\mathrm{HCH}, \gamma-\mathrm{HCH}$, and $\delta-\mathrm{HCH}$, respectively (Siddiqui et al. 2002).

\section{Europe}

In general, the HCB concentration in European mothers' milk is higher than the rest of the world, although the most extreme values of HCB in mothers' milk are not from Europe. Only two European countries, Croatia (Frkovic et al. 1996) and Finland (Shen et al. 2007), report mean HCB concentrations below $10 \mathrm{ng} / \mathrm{g}$ fat, while several Croatian studies report median concentrations above $10 \mathrm{ng} / \mathrm{g}$ fat (Krauthacker et al. 1998, 2009; Romanic and Krauthacker 2006). The majority of the HCB concentrations reported from European countries are in the range of 10-100 ng/g fat, reported on either mean and median basis (Table 4). In Europe, it is primarily the Eastern countries that report highly elevated HCB levels in the analyzed mothers' milk, with the highest levels from the Czech Republic, median values up to $370 \mathrm{ng} / \mathrm{g}$ fat (Cajka and Hajslova 2003; Cerna et al. 2010). However, high levels are also reported in Spanish mothers' milk with medians of 630 and $910 \mathrm{ng} / \mathrm{g}$ fat (Ribas-Fito et al. 2005).

The HCH concentrations in mothers' milk from European mothers in general show significantly lower concentrations than milk from Asia, Australia, and the Pacific regions, but higher than concentrations reported from Africa and the Americas. The reported European levels of $\mathrm{\Sigma HCH}$ are for the most part homogenous, and the majority of mean and/or median concentrations are in the range $10-100 \mathrm{ng} / \mathrm{g}$ fat. However, there are a number of studies from Denmark (Shen et al. 2007), Finland (Shen et al. 2007), Romania (Covaci et al. 2001), and Russia (Polder et al. 1998; Tsydenova et al. 2007) that report $\sum \mathrm{HCH}$ concentrations of several hundreds of nanogram per gram fat (Table 4). The highest reported mean concentration is $1000 \mathrm{ng} / \mathrm{g}$ fat, in a study from Russia (Tsydenova et al. 2007).

\section{The Americas}

Overall, the HCB contamination seems to be lower in the Americas than any of the other regions with a higher portion of studies below $10 \mathrm{ng} / \mathrm{g}$ fat and no study reporting concentrations above $100 \mathrm{ng} / \mathrm{g}$ fat (Table 4). Antigua and Barbuda (UNEP 2009) along with a number of studies from the USA report levels below $10 \mathrm{ng} / \mathrm{g}$ fat. However, two studies report a mean concentration of $15 \mathrm{ng} / \mathrm{g}$ fat (Greizerstein et al. 1999) and a median concentration of $14 \mathrm{ng} / \mathrm{g}$ fat (Fitzgerald et al. 2001). The two highest mean concentrations of HCB were reported in studies of Mexican mothers' milk, reaching 92 and $53 \mathrm{ng} / \mathrm{g}$ fat (Rodas-Ortiz et al. 2008; Waliszewski et al. 1998), and the third highest was reported from Canada, $43 \mathrm{ng} /$ $\mathrm{g}$ fat (Newsome and Ryan 1999).
In the Americas, the $\mathrm{SHCH}$ concentrations are similar to the concentrations in Europe, albeit there are fewer reported observations. The two lowest concentrations are from Antigua and Barbuda (UNEP 2009) and Nicaragua (Romero et al. 2000), 5 and $7 \mathrm{ng} / \mathrm{g}$ fat, respectively. The majority of studies report values in the lower end of the range $10-100 \mathrm{ng} / \mathrm{g}$ (Table 4), although exceptions to this are reported concentrations in the range of hundreds of nanogram per gram from Brazil (Paumgartten et al. 2000) and Mexico (Elvia et al. 2000; Rodas-Ortiz et al. 2008; Waliszewski et al. 1998), with the highest mean concentration reported in mothers' milk from Mexico, at $750 \mathrm{ng} / \mathrm{g}$ fat.

\section{Chlordane}

Chlordane concentrations reported as oxychlordane, $\alpha$-chlordane, $\gamma$-chlordane, and $\sum$ chlordanes from 63 studies, were selected and tabulated (Table 5).

\section{Africa}

Only $\sum$ chlordanes from four countries on the African continent were reported. The highest concentrations were from Senegal, with a mean concentration of $11.7 \mathrm{ng} / \mathrm{g}$ fat (UNEP 2009).

\section{Asia, Australia, and the Pacific region}

Concentrations of oxychlordane vary greatly between countries, mostly between 0.5 and $10 \mathrm{ng} / \mathrm{g}$ fat. Extreme concentrations (140 and $150 \mathrm{ng} / \mathrm{g}$ fat) are reported from one Australian study (Quinsey et al. 1995), whereas the other studies from Australia report concentrations below $20 \mathrm{ng} / \mathrm{g}$ fat. Banned in most countries in 1997, chlordane was still allowed to be used as a termiticide in the Northern Territory (Australia) (UNEP Chemicals). Concentrations of $\alpha$ - and $\gamma$ chlordane are only reported from a few countries, whereof extreme concentrations are reported from Jordan 460 and $590 \mathrm{ng} / \mathrm{g}$ fat, respectively (Nasir et al. 1998). The highest concentrations of $\sum$ chlordanes were reported from Japan (Konishi et al. 2001; Kunisue et al. 2006), while studies from the rest of the countries in the region report concentrations generally below $10 \mathrm{ng} / \mathrm{g}$ fat.

\section{Europe}

Fourteen studies from Europe report mean concentrations of oxychlordane, most of them close to or below $5 \mathrm{ng} / \mathrm{g}$ fat, and the reported median concentrations are in general of the same magnitude. The highest values of oxychlordane in Europe are reported from Ukraine (16-22 ng/g fat) (Gladen et al. 1999, 2003). Only very few countries reported $\sum$ chlordanes, whereof the highest values, $10-60 \mathrm{ng} / \mathrm{g}$ fat, are reported from Russia 


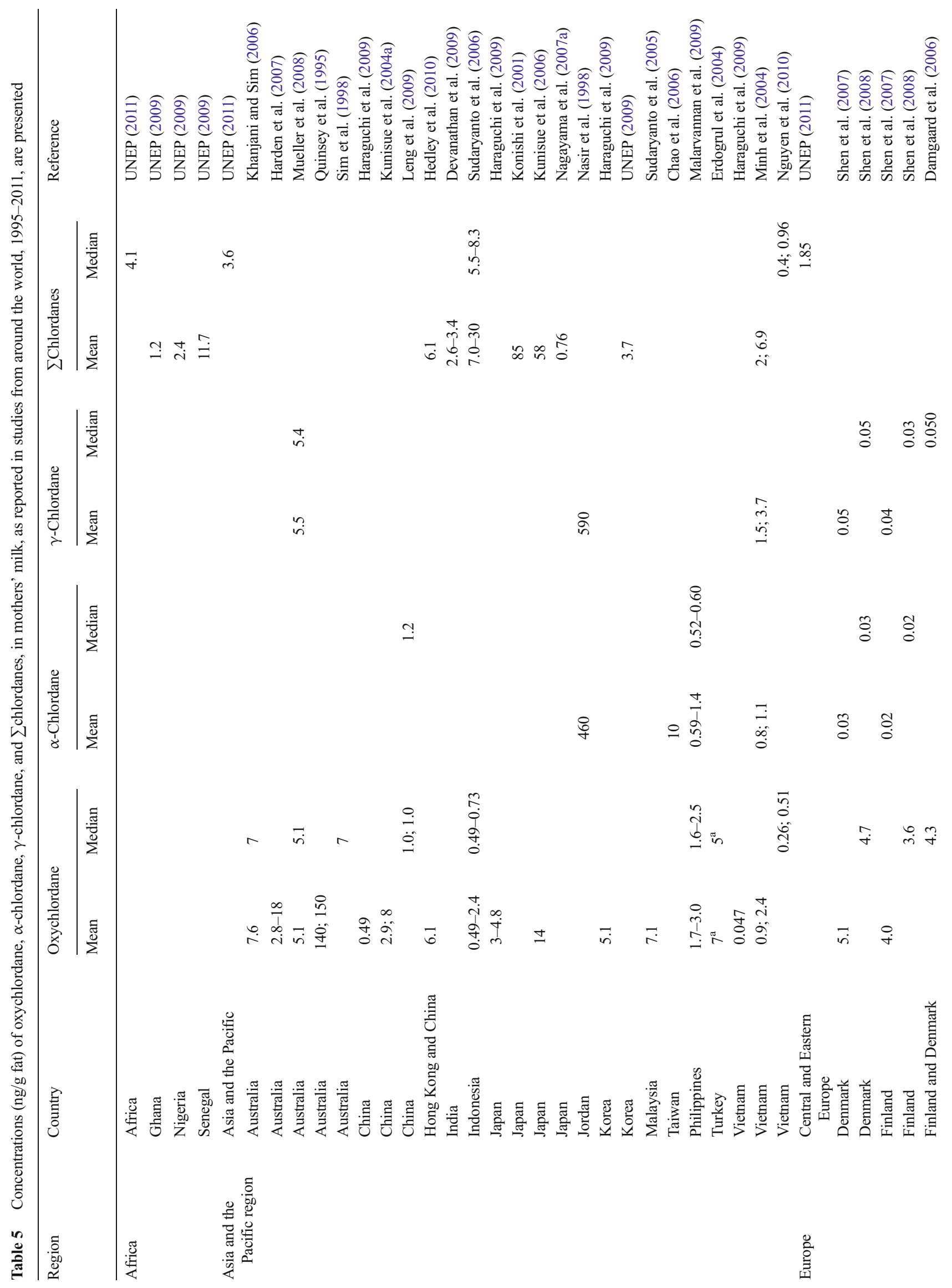




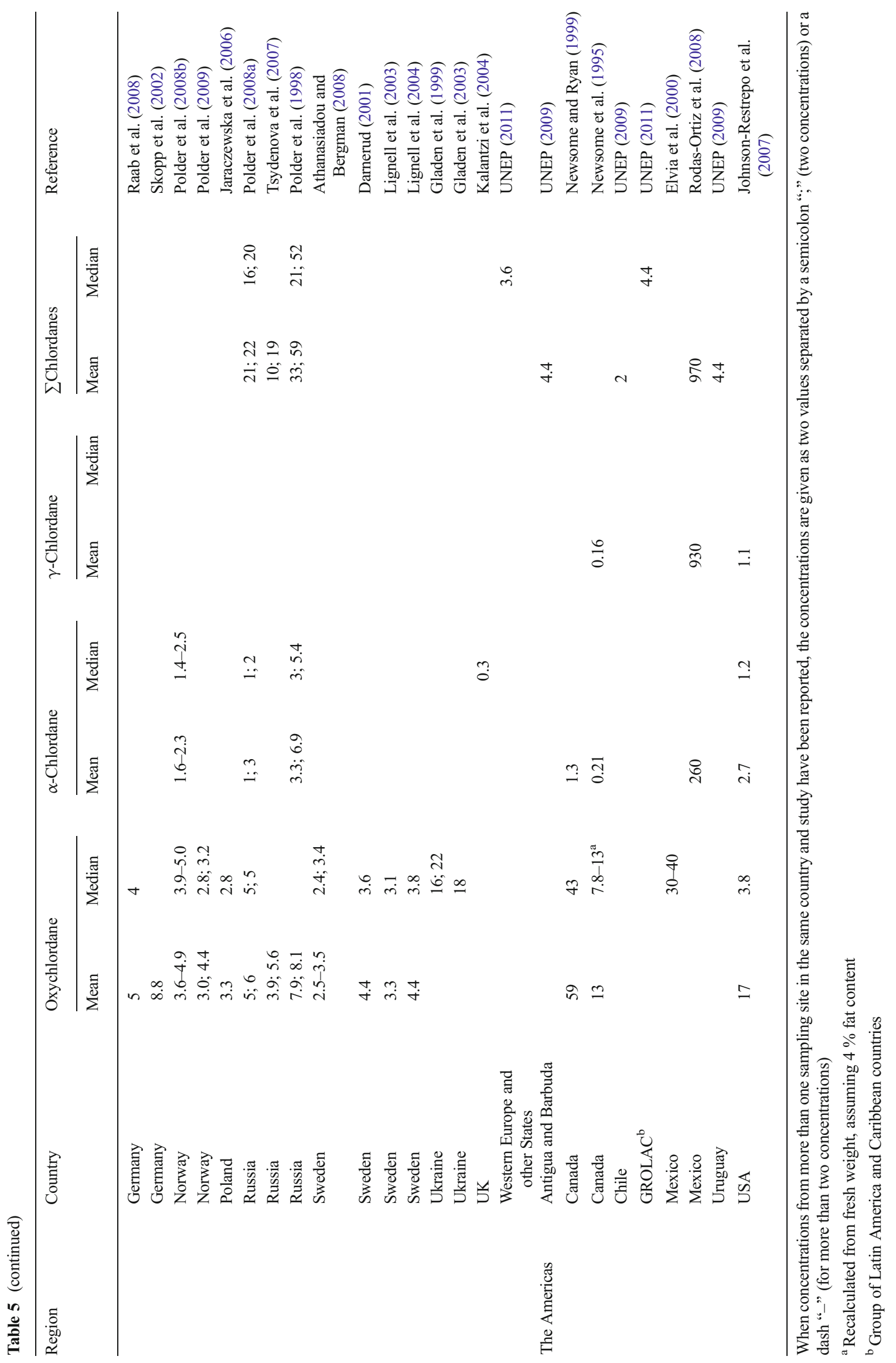


(Polder et al. 1998, 2008a; Tsydenova et al. 2007). One study reports concentrations below $4 \mathrm{ng} / \mathrm{g}$ fat from Western, Central, and Eastern Europe (UNEP 2011).

\section{The Americas}

A few studies from the American continent in general show higher concentration of oxychlordane (Johnson-Restrepo et al. 2007; Newsome et al. 1995; Newsome and Ryan 1999) compared to Europe. The highest concentrations are between 40 and $60 \mathrm{ng} / \mathrm{g}$ fat from Canada (Newsome and Ryan 1999) and Mexico (Elvia et al. 2000). A few studies reporting concentrations of $\alpha$ - and $\gamma$-chlordane give values below $3 \mathrm{ng} / \mathrm{g}$ fat, except extreme concentrations reported from Mexico, 260 and $930 \mathrm{ng} / \mathrm{g}$ fat, respectively (Rodas-Ortiz et al. 2008).

\section{PCDDs, PCDFs, and DL-PCBs}

The polychlorinated dibenzo- $p$-dioxin/polychlorinated dibenzofuran (PCDD/PCDF) and dioxin-like PCB (DL-PCB) concentrations are reported as toxic equivalents (TEQs) based on WHO TEF values from 1998 (Van den Berg et al. 1998) and 2005 (Van den Berg et al. 2006). Total mean TEQ 2005 varies between 3.1 and $7.2 \mathrm{pg}$ TEQs/g fat for the three countries studied in Africa (UNEP 2009). The use of mean or median concentrations applying $\mathrm{TEF}_{1998}$ or $\mathrm{TEF}_{2005}$ results in four different total TEQs. Still, some spatial comparisons are possible. Both Brazil (Paumgartten et al. 2000) and Chile (UNEP 2009) show higher total $\mathrm{TEQ}_{2005}$ than the African countries. When comparing these total $\mathrm{TEQ}_{2005}$ concentrations with mothers' milk from Europe (Table 6), we confirm generally higher TEQs from Europe than the countries mentioned in Africa and South America. Further comparisons are not made here due to the extensive complications in doing so.

\section{PBDEs}

Concentrations of PBDEs, BDE-47, BDE-209, and $\sum$ PBDE data are summarized in Table 7 and Figs. 7 and 8 .

\section{Africa}

Only two studies of PBDEs in mothers' milk from Africa were identified, and both studies confirm the occurrence of BDE-47 in mothers' milk at mean or median concentrations below $2 \mathrm{ng} / \mathrm{g}$ fat (Asante et al. 2011; Darnerud et al. 2011). BDE-209 was only reported in one study from Ghana (Asante et al. 2011).

\section{Asia and the Pacific region}

The concentrations of BDE-47 are rather uniform and low (below $2 \mathrm{ng} / \mathrm{g}$ fat) in mothers' milk in Asia and the Pacific region, even though a very large geographical area is covered. One study from Japan reports the highest level of BDE-47 utside the USA with a mean concentration of $19 \mathrm{ng} / \mathrm{g}$ fat (Akutsu and Hori 2004). From the Philippines, a study reports somewhat elevated levels, mean concentrations of 1.2 and $4.9 \mathrm{ng} / \mathrm{g}$ fat (13). Both low and high BDE-47 concentrations have been determined in samples from Turkey, with mean concentrations reaching $6.0 \mathrm{ng} / \mathrm{g}$ fat (Erdogrul et al. 2004; Ozcan et al. 2011).

BDE-209 was reported in 6 out of 16 studies with similar levels ( $<1 \mathrm{ng} / \mathrm{g}$ fat) independent of the study (cf. Table 7$)$. The highest BDE-209 concentrations are reported in mothers' milk from the Philippines and Vietnam with levels of around $2 \mathrm{ng} / \mathrm{g}$ fat (Malarvannan et al. 2009; Tue et al. 2010).

The reported $\sum$ PBDEs in Asian mothers' milk confirm the observations of BDE-47 concentrations, with the highest concentrations from the Philippines, mean concentrations of 5-10 $\mathrm{ng} / \mathrm{g}$ fat (Malarvannan et al. 2009; Sudaryanto et al. 2008b), as well as from Japan and Turkey with mean concentrations of 31 and $67 \mathrm{ng} / \mathrm{g}$ fat, respectively (Akutsu and Hori 2004; Ozcan et al. 2011). These concentrations are comparable with the levels reported in mothers' milk from the USA.

\section{Europe}

In general, the concentrations of BDE-47 in mothers' milk in Europe (approximately 1-2 ng/g fat) are higher compared to the levels in Asia and the Pacific region and Africa but lower than in the Americas. The lowest levels of BDE-47 in Europe are reported in samples from the Czech Republic, Germany, Italy, and Russia, with mean concentrations below $1 \mathrm{ng} / \mathrm{g}$ fat (Alivernini et al. 2011; Kazda et al. 2004; Polder et al. 2008a; Raab et al. 2008). The highest levels are reported in mothers' milk from the UK with median concentration of $2.7 \mathrm{ng} / \mathrm{g}$ fat (Kalantzi et al. 2004), and the remaining results from Europe are in between the mentioned BDE-47 concentrations (Table 7). Hence, the differences in the levels are rather small.

As few as 7 out of 25 of the European mothers' milk samples report BDE-209, with the highest concentrations in samples from France, $1.5 \mathrm{ng} / \mathrm{g}$ fat (Antignac et al. 2008; Athanasiadou and Bergman 2008). Since BDE-209 has a short half-life in humans, 14 days (Thuresson et al. 2006), the differences in concentrations of this PBDE congener vary greatly. Consequently, exposure levels of BDE-209 and nonaBDEs become uncertain when seen over time.

In Europe, the $\sum$ PBDE concentrations are in general 3$4 \mathrm{ng} / \mathrm{g}$ fat, with a few exceptions (Table 7). The highest $\sum$ PBDE concentrations are reported in mothers' milk from the UK, with median levels of $6.3 \mathrm{ng} / \mathrm{g}$ fat, which is still three to five times lower than levels reported from the USA. 


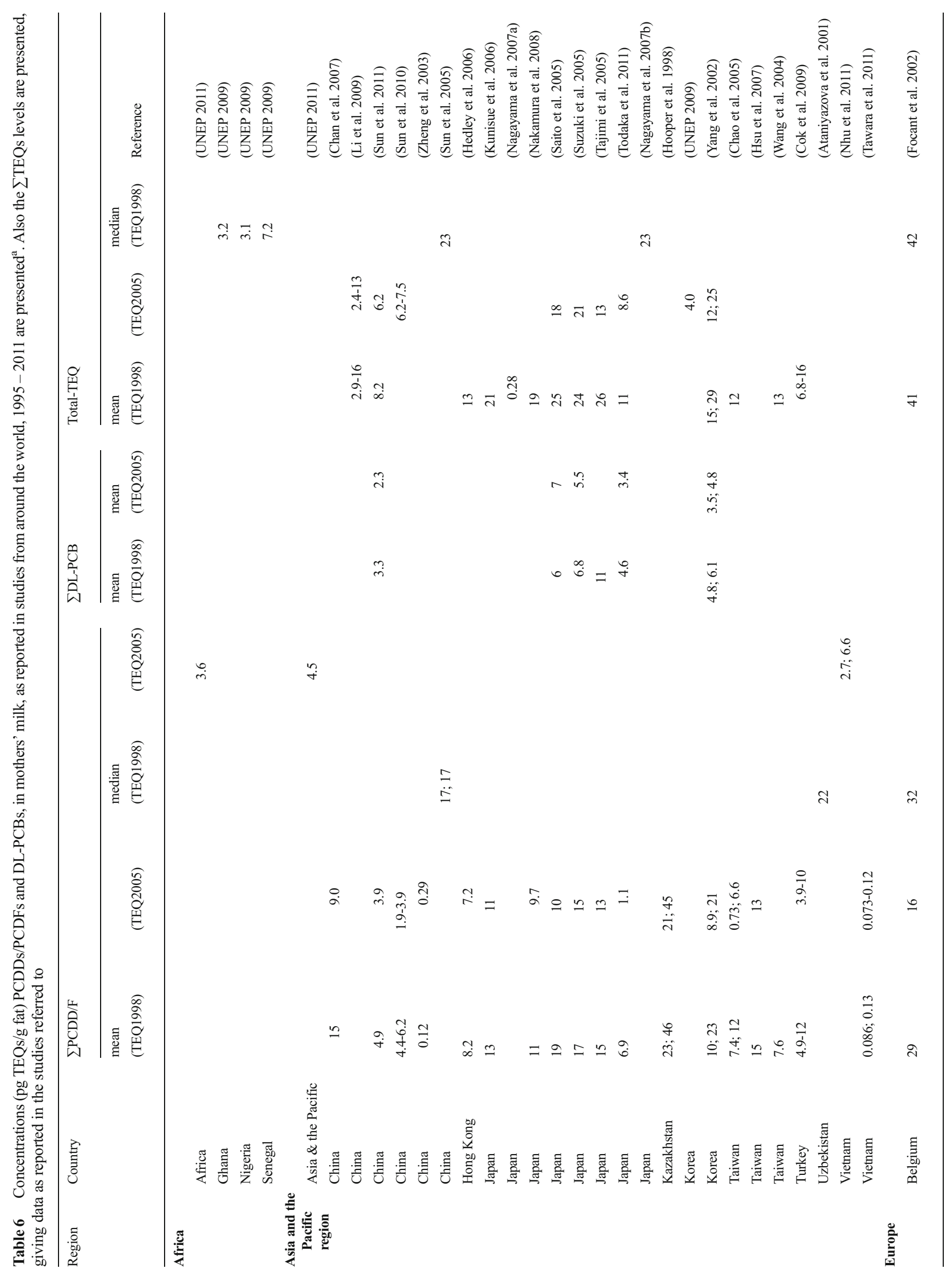




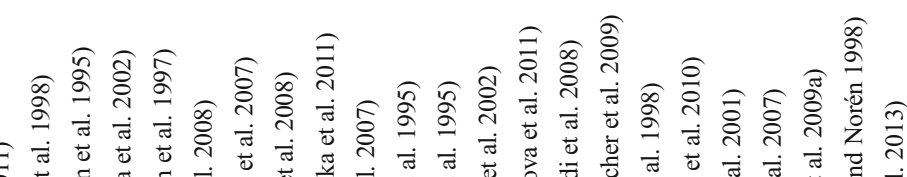

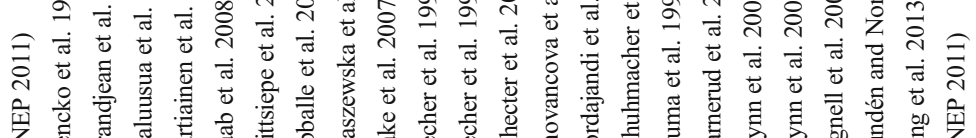

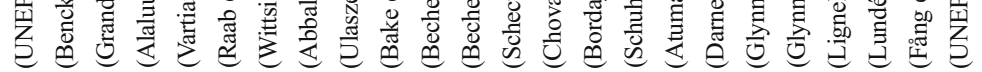

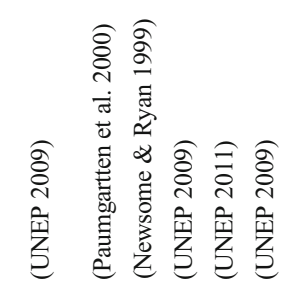

$\stackrel{2}{\ddot{ \pm}}$

$\cong n$

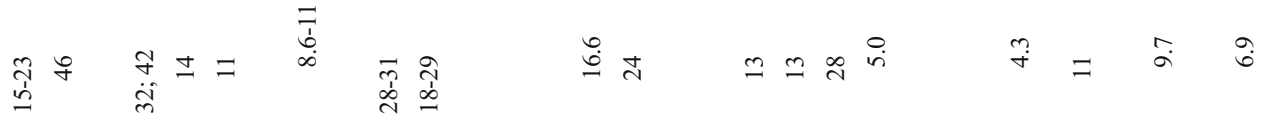

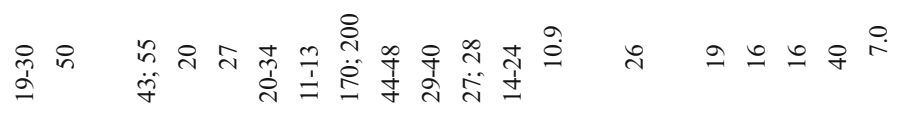

$\pm \stackrel{\infty}{\frac{1}{n}}$

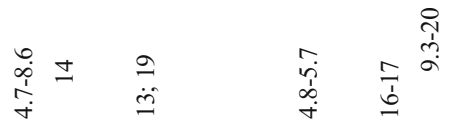

$a \simeq$ in $\infty$ กับ

$\stackrel{8}{\circ}$

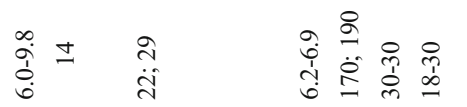

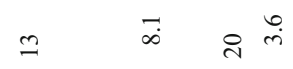

$\stackrel{+}{+}$

in

$\stackrel{+}{\because} \quad \stackrel{0}{0}$

$\ddot{i}$

$\underset{\substack{\simeq \\ \infty}}{\stackrel{1}{0}}$

a $\stackrel{r}{\pi}$

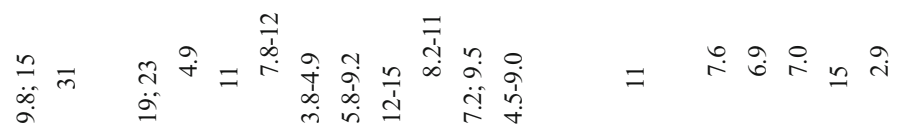

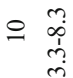

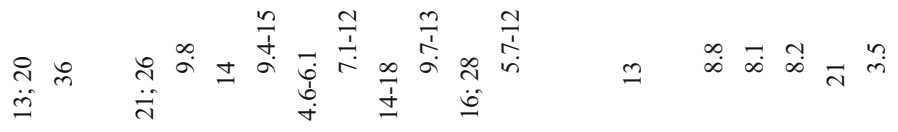

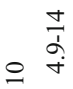

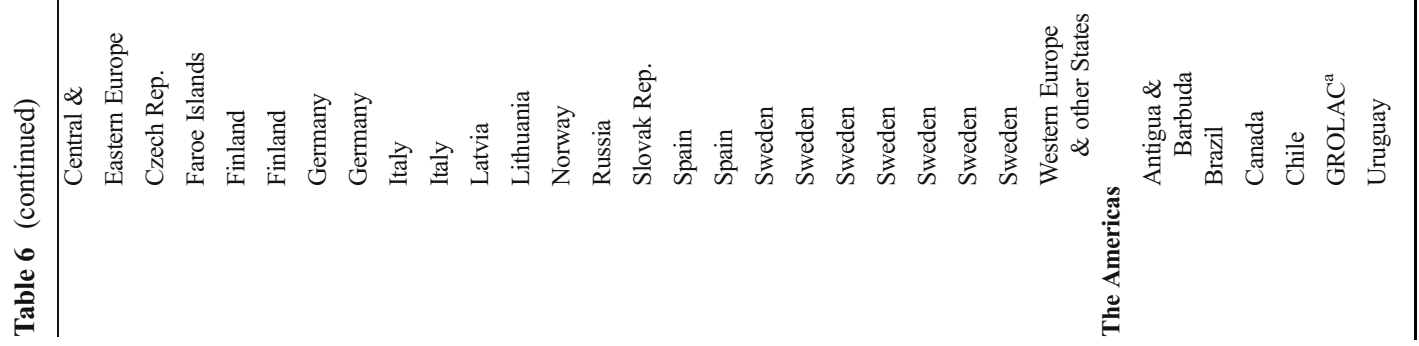




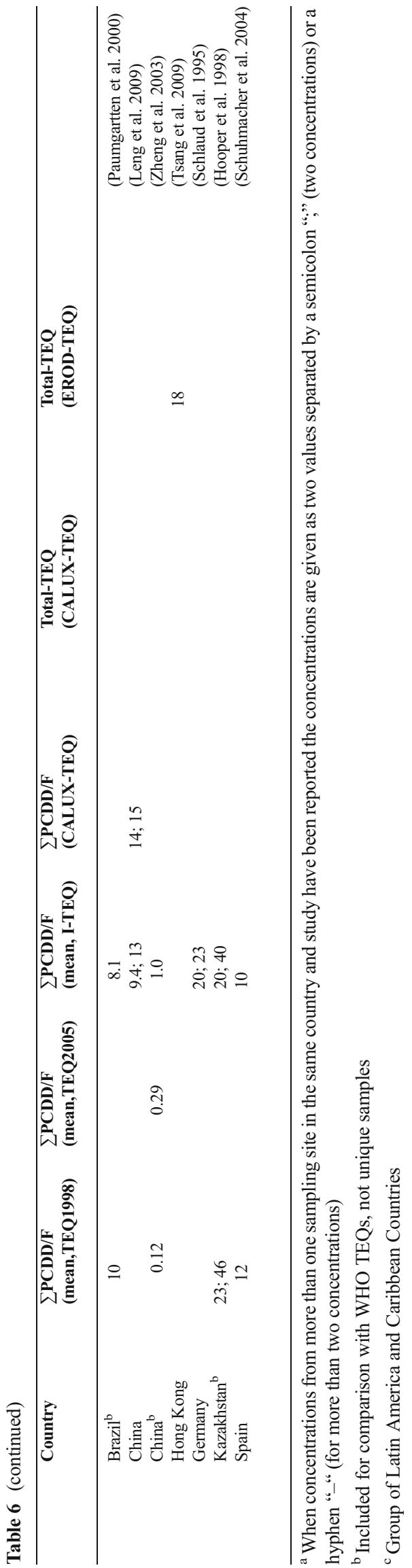

The Americas

Only studies from the USA could be found that report levels of PBDEs from the Americas and that met the criteria set for this review.

In general, the reported levels of BDE-47 are much higher in the mothers' milk samples from the USA compared to the rest of the world. The concentrations are rather uniform, with mean values at 35-40 ng/g fat (Johnson-Restrepo et al. 2007; Schecter et al. 2003, 2005, 2010), but with levels reaching as high as $73 \mathrm{ng} / \mathrm{g}$ fat (Park et al. 2011). Also, the levels of BDE209 are higher in the USA than the rest of the world (Table 7), which is indicating a higher prevalence of deca-BDE exposure.

Also, the concentrations of $\sum$ PBDEs in the samples from the USA are overall similar, with means of 66-76 $\mathrm{ng} / \mathrm{g}$ fat, and one median value of 51, reported in four different studies (Johnson-Restrepo et al. 2007; Schecter et al. 2003, 2005, 2010). However, one study reports a mean concentration as high as $130 \mathrm{ng} / \mathrm{g}$ fat (Park et al. 2011).

The results clearly show that US mothers' milk contains the highest concentrations of PBDEs. This is in line with any other exposure study from the USA, showing mothers and other individuals being subjected to environmental exposures of PBDEs that are the highest in the world.

\section{Heptachlor}

Heptachlor concentrations reported as cis-HCL-epoxide, HCL-epoxide, and heptachlor from 49 studies were selected and tabulated (Table 8). Concentrations of cis-HCL-epoxide are only reported from one or a few countries from each continent/region, and they range between $0.7 \mathrm{ng} / \mathrm{g}$ fat in China (Hedley et al. 2010) and $8 \mathrm{ng} / \mathrm{g}$ fat in Brazil (Paumgartten et al. 2000).

Africa

Heptachlor was only reported from four regions of the African continent with concentrations ranging between 0.9 and $2.25 \mathrm{ng} / \mathrm{g}$ fat (UNEP 2009, 2011).

Asia, Australia, and the Pacific region

Fifteen studies report concentrations of HCL-epoxide. Most of these report concentrations below $10 \mathrm{ng} / \mathrm{g}$ fat, but higher concentrations are reported from Australia, 53 and $78 \mathrm{ng} / \mathrm{g}$ fat (Quinsey et al. 1995); Jordan, $190 \mathrm{ng} / \mathrm{g}$ fat (Nasir et al. 1998); Thailand, $60 \mathrm{ng} / \mathrm{g}$ fat (Stuetz et al. 2001); and Turkey, $61 \mathrm{ng} / \mathrm{g}$ fat (Cok et al. 2005). The highest reported concentration of heptachlor is from Jordan at $500 \mathrm{ng} / \mathrm{g}$ fat (Nasir et al. 1998). 
Table 7 Concentrations (ng/g fat) of BDE-47, BDE-209, and $\sum$ PBDE, in mothers' milk, as reported in studies from around the world, 1995-2011, are presented

\begin{tabular}{|c|c|c|c|c|c|c|c|c|c|c|}
\hline \multirow[t]{2}{*}{ Region } & \multicolumn{4}{|l|}{ BDE-47 } & \multicolumn{2}{|l|}{ BDE-209 } & \multicolumn{3}{|l|}{$\sum \mathrm{PBDE}$} & \multirow[t]{2}{*}{ Reference } \\
\hline & Country & Mean & Median & Geo. mean & Mean & Median & Mean & Median & Geo. mean & \\
\hline \multirow[t]{2}{*}{ Africa } & Ghana & $0.77-2.1$ & $0.49-1.7$ & & $0.83-1.4$ & $0.39-0.95$ & $2.2-5.8$ & $1.3-4.3$ & & Asante et al. (2011) \\
\hline & South Africa & 0.29 & 0.3 & & & & 1.7 & 1.4 & & Darnerud et al. (2011) \\
\hline \multirow{18}{*}{$\begin{array}{l}\text { Asia and the } \\
\text { Pacific } \\
\text { region }\end{array}$} & China & 0.89 & & & & & 1.9 & & & Haraguchi et al. (2009) \\
\hline & China & $0.33 ; 0.66$ & $0.32 ; 0.62$ & & $0.95 ; 1.3$ & 1.8 & $4.7 ; 7.7$ & $2.8 ; 7.1$ & & $\begin{array}{l}\text { Sudaryanto et al. } \\
\text { (2008b) }\end{array}$ \\
\hline & China & $0.23-0.74$ & $0.22-0.71$ & & $0.22-0.70$ & $0.22-0.57$ & $3.4-4.2$ & $2.2-4.1$ & & Sun et al. (2010) \\
\hline & China & $0.21-0.73$ & & & & & $0.85-3.0$ & & & Zhang et al. (2011) \\
\hline & $\begin{array}{l}\text { Hong Kong and } \\
\text { South China }\end{array}$ & 1.9 & & & & & 3.4 & & & Hedley et al. (2010) \\
\hline & Indonesia & $0.22-0.58$ & & & $0.53 ; 0.54$ & & $0.91-1.8$ & & & $\begin{array}{l}\text { Sudaryanto et al. } \\
\text { (2008a) }\end{array}$ \\
\hline & Japan & 0.37 & & & & & 1.4 & & & Akutsu et al. (2003) \\
\hline & Japan & 19 & 0.58 & & & & 31 & 1.5 & & Akutsu and Hori (2004) \\
\hline & Japan & $0.57-0.76$ & & & & & $1.3-1.7$ & & & Haraguchi et al. (2009) \\
\hline & Japan & $2.1^{\mathrm{a}}$ & $0.43^{\mathrm{a}}$ & & & & 4.6 & 3 & & Kawashiro et al. (2008) \\
\hline & Korea & 2 & & & & & 3.7 & & & Haraguchi et al. (2009) \\
\hline & Korea & 1.2 & & & & & 2.7 & & & Kim et al. (2011b) \\
\hline & Philippines & $1.2 ; 4.9$ & $1.1 ; 1.2$ & & 1.8 & 1.8 & $2.6 ; 10$ & $2.7 ; 4.2$ & & $\begin{array}{l}\text { Malarvannan et al. } \\
\text { (2009) }\end{array}$ \\
\hline & Taiwan & 0.58 & 0.52 & & 0.48 & 0.36 & 3.5 & 3.3 & & Koh et al. (2010) \\
\hline & Turkey & $0.15^{\mathrm{a}}$ & $0.1^{\mathrm{a}}$ & & & & $0.2^{\mathrm{a}}$ & $0.1^{\mathrm{a}}$ & & Erdogrul et al. (2004) \\
\hline & Turkey & 6.0 & 3.3 & & & & 67 & 43 & & Ozcan et al. (2011) \\
\hline & Vietnam & 0.19 & & & & & 0.42 & & & Haraguchi et al. (2009) \\
\hline & Vietnam & & $0.13 ; 0.40$ & & & $0.57 ; 2.3$ & & $1.1 ; 4.0$ & & Tue et al. (2010) \\
\hline \multirow[t]{21}{*}{ Europe } & Czech Republic & 0.86 & 0.61 & & & & & & & Kazda et al. (2004) \\
\hline & France & & & & & 1.5 & & 2.7 & & Antignac et al. (2008) \\
\hline & Germany & 0.67 & 0.48 & & & & 2.0 & 1.6 & & Raab et al. (2008) \\
\hline & Italy & 0.82 & & & & & 1.3 & & & Alivernini et al. (2011) \\
\hline & Norway & 1.7 & 0.95 & & 0.5 & 0.25 & 3.3 & 1.9 & & Eggesbo et al. (2011) \\
\hline & Norway & 1.7 & 1.3 & & 0.22 & 0.13 & 3.8 & 3.2 & & Polder et al. (2008b) \\
\hline & Norway & 1.7 & & & & 0.32 & 3.4 & 2.1 & & Thomsen et al. (2010) \\
\hline & Poland & 1.1 & 0.73 & & & & 2.5 & 2 & & Jaraczewska et al. (2006) \\
\hline & Russia & $0.43 ; 0.65$ & $0.36 ; 0.58$ & & 0.35 & 0.19 & $1.1 ; 1.2$ & $0.96 ; 1.1$ & & Polder et al. (2008a) \\
\hline & Russia & & & & & & & 0.96 & & Tsydenova et al. (2007) \\
\hline & Spain & & & & & & 0.33 & & & Bordajandi et al. (2008) \\
\hline & Spain & & & & & & & 2.5 & & $\begin{array}{l}\text { Schuhmacher et al. } \\
\text { (2009) }\end{array}$ \\
\hline & Sweden & $1.6 ; 2$ & & & $0.2 ; 1.5$ & & $3.9 ; 4.8$ & & & $\begin{array}{l}\text { Athanasiadou and } \\
\text { Bergman (2008) }\end{array}$ \\
\hline & Sweden & 1.79 & 1.3 & & & & 3.0 & 2.4 & & Aune et al. (2002) \\
\hline & Sweden & $0.93 ; 2.4$ & 0.71 & & 0.66 & & $2.1 ; 4.3$ & 1.9 & & Bergman et al. (2010) \\
\hline & Sweden & 1.9 & 1.7 & & & & 3.2 & 3.2 & & Darnerud (2001) \\
\hline & Sweden & 0.92 & & & & & 2.4 & & & Fängström et al. (2008) \\
\hline & Sweden & & $1.2-1.8$ & & & & & $2.2-3.3$ & & Glynn et al. (2011) \\
\hline & Sweden & & 1.2 & & & & & & & Guvenius et al. (2003) \\
\hline & Sweden & 1.8 & 1.3 & & & & 3.4 & 2.8 & & Lignell et al. (2003) \\
\hline & Sweden & 1.2 & 0.76 & & & & & & & Lignell et al. (2009b) \\
\hline
\end{tabular}


Table 7 (continued)

\begin{tabular}{|c|c|c|c|c|c|c|c|c|c|c|}
\hline \multirow[t]{2}{*}{ Region } & \multicolumn{4}{|l|}{ BDE-47 } & \multicolumn{2}{|c|}{ BDE-209 } & \multicolumn{3}{|c|}{$\sum$ PBDE } & \multirow[t]{2}{*}{ Reference } \\
\hline & Country & Mean & Median & Geo. mean & Mean & Median & Mean & Median & Geo. mean & \\
\hline & Sweden & 1.9 & 1.5 & & & & 3.5 & 2.9 & & Lignell et al. (2009a) \\
\hline & Sweden & 1.5 & 1.5 & & & & 2.6 & 2.5 & & Lind et al. (2003) \\
\hline & Sweden & 2.3 & & & & & 4.0 & & & Meironyté et al. (1999) \\
\hline & UK & & 2.7 & 3.0 & & & & 6.3 & 6.6 & Kalantzi et al. (2004) \\
\hline \multirow[t]{6}{*}{ The Americas } & USA & & 28 & & & & & 51 & & Daniels et al. (2010) \\
\hline & USA & 41 & 7.7 & & & & 75 & 20 & & $\begin{array}{l}\text { Johnson-Restrepo et al. } \\
\text { (2007) }\end{array}$ \\
\hline & USA & 73 & & & 3.7 & 1.4 & 130 & & & Park et al. (2011) \\
\hline & USA & 41 & 18 & & 0.92 & & 74 & 34 & & Schecter et al. (2003) \\
\hline & USA & 36 & 17 & & 1.4 & 0.10 & 66 & 30 & & Schecter et al. (2005) \\
\hline & USA & 36 & 24 & & & & 76 & 40 & & Schecter et al. (2010) \\
\hline
\end{tabular}

When concentrations from more than one sampling site in the same country and study are reported, the concentrations are given as two values separated by a semicolon (two concentrations) or a dash (for more than two levels)

${ }^{\text {a }}$ Recalculated from fresh weight, assuming $4 \%$ fat content

\section{Europe}

Concentrations of HCL-epoxide reported from Europe are in most cases below or close to $3 \mathrm{ng} / \mathrm{g}$ fat, although higher concentrations are reported from Ukraine, 16-22 ng/g fat (Gladen et al. 1999, 2003), and the Netherlands, $30 \mathrm{ng} / \mathrm{g}$ fat (Albers et al. 1996).

\section{The Americas}

Concentrations of HCL-epoxide and heptachlor from the Americas are reported as less than $4 \mathrm{ng} / \mathrm{g}$ fat except for Mexico, 160 and $580 \mathrm{ng} / \mathrm{g}$ fat, respectively (Rodas-Ortiz et al. 2008).
Dieldrin, endrin, and aldrin

The OCPs discussed herein were regulated at an early stage in many countries. Despite of this, rather high concentrations of dieldrin are reported (Table 9).

\section{Africa}

No studies were retrieved that report aldrin and/or endrin in mothers' milk from any African nation. Dieldrin was reported in seven studies, three of which were part of the UNEP screening program with the lowest levels in mothers' milk from Ghana, Nigeria, and Senegal, with mean concentrations of $1.3-4.1 \mathrm{ng} / \mathrm{g}$ fat (UNEP 2009).
Fig. 7 Graphical presentation of BDE-47 concentrations in mothers' milk from countries worldwide $\mathrm{ng} / \mathrm{g}$ fa

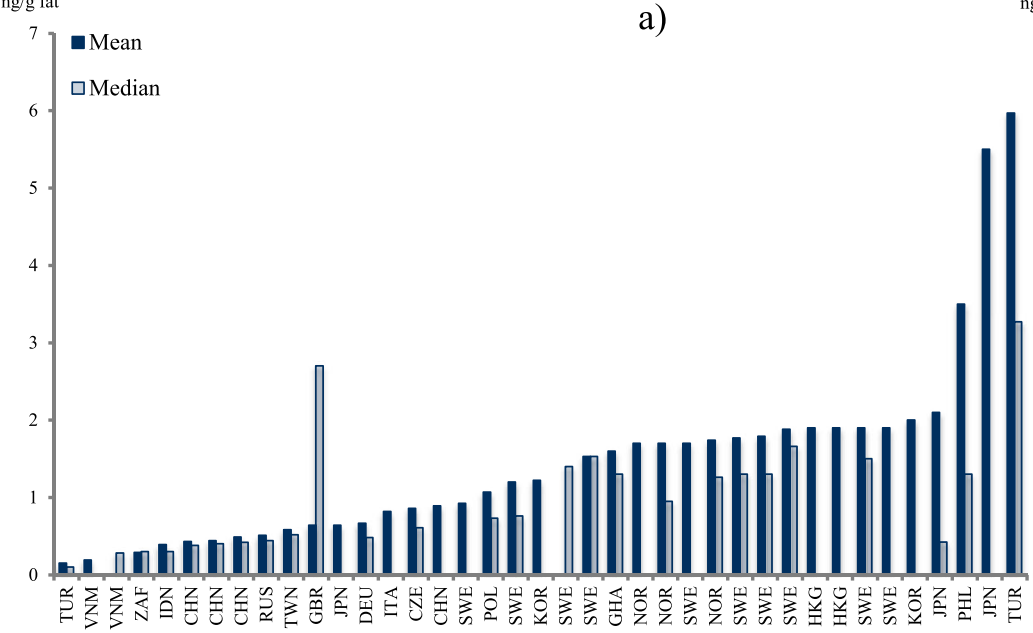

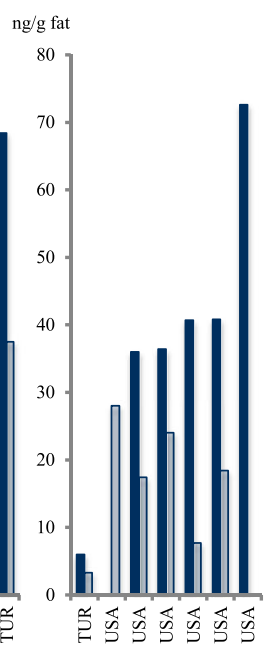




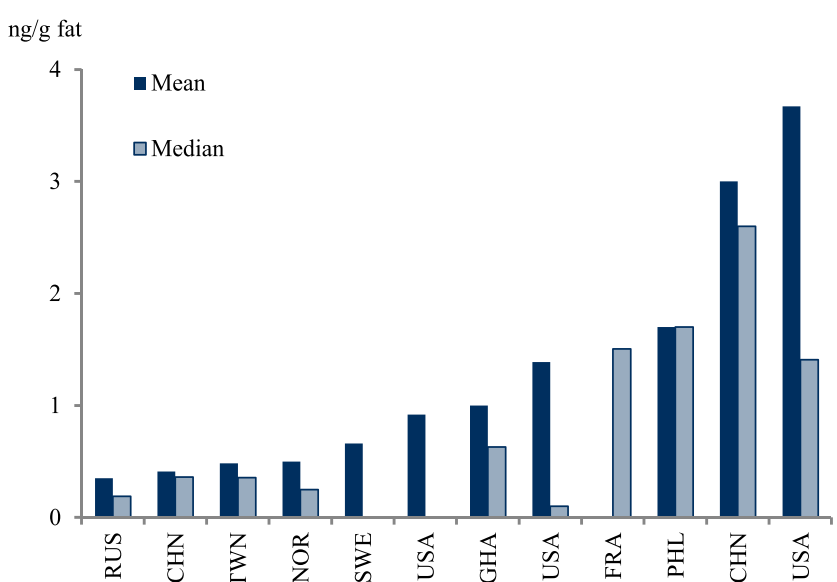

Fig. 8 Graphical presentation of BDE-209 concentrations in mothers' milk from countries worldwide.

However, some reports indicate levels of up to 25$120 \mathrm{ng} / \mathrm{g}$ fat (Ennaceur et al. 2007, 2008; Ntow et al. 2008).

\section{Asia and the Pacific region}

Although only few studies report aldrin concentrations in mothers' milk, the variation is great. The most comprehensive study originates from Australia showing a large national spatial distribution in a range $0.01-0.68 \mathrm{ng} / \mathrm{g}$ fat (Harden et al. 2007). Somewhat higher levels of aldrin are found in Kuwait and the highest concentration are from India and Jordan with mean concentrations up to $860 \mathrm{ng} / \mathrm{g}$ fat (Nasir et al. 1998; Siddiqui et al. 2002).

Dieldrin is more frequently reported in mothers' milk than aldrin and endrin and at rather high concentrations (Table 9). The levels of dieldrin are rarely above $100 \mathrm{ng} / \mathrm{g}$ fat, with the exceptions of one study from Jordan, which reports a mean concentration of $1400 \mathrm{ng} / \mathrm{g}$ fat (Nasir et al. 1998), and one study from China, 9300-10,000 ng/g fat (Wang et al. 2008). Only two studies have been retrieved reporting on endrin in mothers' milk, one from Jordan and one from Kuwait (Nasir et al. 1998; Saeed et al. 2000).

\section{Europe}

A study from Croatia reports aldrin and endrin in their samples, with mean concentrations of 1.3 and $2.0 \mathrm{ng} / \mathrm{g}$ fat, respectively (Frkovic et al. 1996). Again, the occurrence of dieldrin in mothers' milk is frequently reported from European countries in low concentrations, for example in samples from Germany and Croatia, with mean concentrations below $3.8 \mathrm{ng} / \mathrm{g}$ fat (Frkovic et al. 1996; Zietz et al. 2008). However, other studies from Germany show higher levels, with mean concentrations of 4 and $14 \mathrm{ng} / \mathrm{g}$ fat (Raab et al.
2008; Schlaud et al. 1995). Two reports investigating dieldrin levels in mothers' milk, both in Denmark and Finland, show similar results (Shen et al. 2007, 2008) and likewise from the WHO-UNEP monitoring program (UNEP 2011). The highest levels are reported from the UK with a mean concentration of $48 \mathrm{ng} / \mathrm{g}$ fat (Harris et al. 1999) and the Netherlands with a median concentration of $50 \mathrm{ng} / \mathrm{g}$ fat (Albers et al. 1996).

\section{The Americas}

In the Americas, one study has reported levels of aldrin from a known pest-controlled area on the Yucatán peninsula in Mexico with a mean concentration of $280 \mathrm{ng} / \mathrm{g}$ fat (RodasOrtiz et al. 2008). In the lower end of reported levels of dieldrin in mothers' milk are samples from the Americas, Antigua and Barbuda, Chile, and Uruguay, with mean concentrations of 2.6, 5.0, and $4.9 \mathrm{ng} / \mathrm{g}$ fat (UNEP 2009), respectively, as well as from the Group of Latin American and Caribbean countries, with a median concentration of $4.9 \mathrm{ng} / \mathrm{g}$ fat (UNEP 2011). The highest levels of dieldrin in mothers' milk in the Americas are found in samples from a know pest-controlled area in on the Yucatán peninsula in Mexico with a mean concentration of $300 \mathrm{ng} / \mathrm{g}$ fat (Rodas-Ortiz et al. 2008). Endrin could only be found in a sample from Nicaragua (Romero et al. 2000) and from the abovementioned pestcontrolled area on the Yucatán peninsula in Mexico (RodasOrtiz et al. 2008).

\section{Pentachlorobenzene, toxaphene, and mirex}

Pentachlorobenzene (PCBz), mirex, and toxaphene concentrations in mothers' milk are only reported in a few studies (Table 10). Mirex levels are reported as 16, 20, and $68 \mathrm{ng} / \mathrm{g}$ fat in mothers' milk from Germany, Russia, and Canada, respectively (Newsome and Ryan 1999; Polder et al. 2008a; Skopp et al. 2002). Both PCBz and mirex are reported in around $1 \mathrm{ng} /$ $\mathrm{g}$ fat in most mothers' milk samples, with a few exceptions (Table 10). The most profound exception is mirex found in a concentration of $200 \mathrm{ng} / \mathrm{g}$ fat in mothers' milk from Mexico (Rodas-Ortiz et al. 2008).

It is notable that so few reports have been published on these POPs. Therefore, any assessments of spatial differences are impossible.

\section{HBCDD and PBB}

Concentrations of hexabromocyclododecane (HBCDD) and polybrominated biphenyl (PBB) reported in mothers' milk are presented in Table 11 on a fat weight basis. From isomer-specific information, it is clear that $\alpha$-HBCDD is the most abundant isomer of environmental HBCDDs (Eljarrat et al. 2009; Lankova et al. 2013). The spatial distribution of HBCDD is illustrated in Fig. 9. 
Table 8 Concentrations (ng/g fat) of cis-HCL-epoxide, HCL-epoxide, and heptachlor, in mothers' milk, as reported in studies from around the world, 1995-2011, are presented

\begin{tabular}{|c|c|c|c|c|c|c|c|}
\hline \multirow[t]{2}{*}{ Region } & \multirow[t]{2}{*}{ Country } & \multirow{2}{*}{$\frac{\text { cis-HCL-epoxide }}{\text { Mean }}$} & \multicolumn{2}{|c|}{ HCL-epoxide } & \multicolumn{2}{|c|}{ Heptachlor } & \multirow[t]{2}{*}{ Reference } \\
\hline & & & Mean & Median & Mean & Median & \\
\hline \multirow[t]{4}{*}{ Africa } & Africa & & & & & 2.25 & UNEP (2011) \\
\hline & Ghana & & & & 0.9 & & UNEP (2009) \\
\hline & Nigeria & & & & 0.9 & & UNEP (2009) \\
\hline & Senegal & & & & 1.3 & & UNEP (2009) \\
\hline \multirow{18}{*}{$\begin{array}{l}\text { Asia and the Pacific } \\
\text { region }\end{array}$} & Asia and the Pacific & & & & & 0.55 & UNEP (2011) \\
\hline & Australia & & $2.2-17$ & 7.4 & & & Harden et al. (2007) \\
\hline & Australia & & 5.9 & 6 & & & Mueller et al. (2008) \\
\hline & Australia & & $53 ; 78$ & & & & Quinsey et al. (1995) \\
\hline & Australia & & & 7 & & & Sim et al. (1998) \\
\hline & Australia & & 9.9 & 7 & & & Khanjani and Sim (2006) \\
\hline & China & 0.7 & & & & & Hedley et al. (2010) \\
\hline & Iran & & 54 & & & & Cok et al. (1999) \\
\hline & Japan & & 7.5 & & & & Konishi et al. (2001) \\
\hline & Japan & & 7.4 & & & & Saito et al. (2005) \\
\hline & Japan & & 3 & & & & Nagayama et al. (2007a) \\
\hline & Jordan & & 190 & & 500 & & Nasir et al. (1998) \\
\hline & Korea & & & & 2.2 & & UNEP (2009) \\
\hline & Kuwait & & 1.3 & & & & Saeed et al. (2000) \\
\hline & Taiwan & & 4.3 & & 3 & & Chao et al. (2006) \\
\hline & Thailand & & $160^{\mathrm{a}}$ & $110^{\mathrm{a}}$ & $110^{\mathrm{a}}$ & $110^{\mathrm{a}}$ & Stuetz et al. (2001) \\
\hline & Turkey & & 61 & & & & Cok et al. (2005) \\
\hline & Turkey & & 38 & & & & Cok et al. (2011) \\
\hline \multirow[t]{15}{*}{ Europe } & Central and Eastern Europe & & & & & 0.50 & UNEP (2011) \\
\hline & Croatia & & 0.7 & & & & Frkovic et al. (1996) \\
\hline & Denmark & & & 2.9 & & & Shen et al. (2008) \\
\hline & Denmark & 2.8 & & & & & Shen et al. (2007) \\
\hline & Denmark and Finland & & & 2.3 & & & Damgaard et al. (2006) \\
\hline & Finland & & & 2.0 & & & Shen et al. (2008) \\
\hline & Finland & 2.2 & & & & & Shen et al. (2007) \\
\hline & Germany & & 4 & 3 & & & Raab et al. (2008) \\
\hline & Germany & & & & $21 ; 22$ & & Schlaud et al. (1995) \\
\hline & Germany & & 0.11 & & & & Zietz et al. (2008) \\
\hline & Germany & 7.3 & & & & & Skopp et al. (2002) \\
\hline & Netherlands & & & 30 & & & Albers et al. (1996) \\
\hline & Spain & & & & $9^{\mathrm{a}}$ & & Pico et al. (1995) \\
\hline & Ukraine & & & 22 & & & Gladen et al. (1999) \\
\hline & Ukraine & & & 16 & & & Gladen et al. (2003) \\
\hline \multirow[t]{8}{*}{ The Americas } & Antigua and Barbuda & & & & 1.4 & & UNEP (2009) \\
\hline & Brazil & 8 & & & & & Paumgartten et al. (2000) \\
\hline & Canada & & 0.94 & & & & Newsome and Ryan (1999) \\
\hline & Canada & & 3.8 & $0.75-3.2^{\mathrm{a}}$ & & & Newsome et al. (1995) \\
\hline & Chile & & & & 1.7 & & UNEP (2009) \\
\hline & GROLAC $^{\mathrm{b}}$ & & & & & 1.4 & UNEP (2011) \\
\hline & Mexico & & & 40 & & & Elvia et al. (2000) \\
\hline & Mexico & & 160 & & 580 & & Rodas-Ortiz et al. (2008) \\
\hline
\end{tabular}


Table 8 (continued)

\begin{tabular}{|c|c|c|c|c|c|c|c|}
\hline \multirow[t]{2}{*}{ Region } & \multirow[t]{2}{*}{ Country } & \multirow{2}{*}{$\frac{\text { cis-HCL-epoxide }}{\text { Mean }}$} & \multicolumn{2}{|c|}{ HCL-epoxide } & \multicolumn{2}{|c|}{ Heptachlor } & \multirow[t]{2}{*}{ Reference } \\
\hline & & & Mean & Median & Mean & Median & \\
\hline & Nicaragua & & 6 & & 1 & & Romero et al. (2000) \\
\hline & Uruguay & & & & 1 & & UNEP (2009) \\
\hline & Western Europe and other States & & & & & 0.8 & UNEP (2011) \\
\hline
\end{tabular}

When concentrations from more than one sampling site in the same country and study have been reported, the concentrations are given as two values separated by a semicolon ";" (two concentrations) or a dash "-" (for more than two concentrations)

${ }^{a}$ Recalculated from fresh weight, assuming $4 \%$ fat content

${ }^{\mathrm{b}}$ Group of Latin America and Caribbean countries

\section{Africa}

Only two studies of HBCDDs in mothers' milk from all of Africa were retrieved, both showing subnanogram per gram fat concentrations in the mothers' milk analyzed (Asante et al. 2011; Darnerud et al. 2011). No study was found reporting on PBBs in mothers' milk from any African nation.

\section{Asia and the Pacific region}

The lowest concentrations of $\sum$ HBCDDs reported in mothers' milk from Asia come from the Philippines and Vietnam with mean and median concentrations below $1 \mathrm{ng} / \mathrm{g}$ fat (Malarvannan et al. 2009; Tue et al. 2010). A study from China shows a greater range in $\Sigma$ HBCDD concentrations, with means of $0.33-2.8 \mathrm{ng} / \mathrm{g}$ fat (Shi et al. 2009). In Japanese mothers' milk, $\sum$ HBCDDs levels of $1.4 \mathrm{ng} / \mathrm{g}$ fat (Kakimoto et al. 2008) are reported. No study was found reporting on PBBs in mothers' milk from any nation in Asia or the Pacific region.

\section{Europe}

The levels of $\sum$ HBCDDs in Europe are quite uniform and low (Table 11), i.e., $<1 \mathrm{ng} / \mathrm{g}$ fat. However, the highest concentrations on a global scale are those reported from a Spanish study, with a mean concentration of $47 \mathrm{ng} / \mathrm{g}$ fat, in mothers' milk from a population living close to a textile processing plant (Eljarrat et al. 2009). The $\sum$ HBCDD concentrations in Swedish samples reported median concentrations within the range of $0.3-0.4 \mathrm{ng} / \mathrm{g}$ fat (Glynn et al. 2011). Somewhat higher concentrations, and comparable with the Japanese levels, are reported from Norway, with mean concentrations of $1.7 \mathrm{ng} / \mathrm{g}$ fat (Thomsen et al. 2010). The $\sum$ HBCDDs in mothers' milk from the UK report a mean concentration of $6.0 \mathrm{ng} / \mathrm{g}$ fat (Abdallah and Harrad 2011), which is the highest background level worldwide, apart from the Spanish "hot spot" samples. One study reports PBB concentrations from two countries,
Denmark and Finland, both indicating mean concentrations below $0.3 \mathrm{ng} / \mathrm{g}$ fat (Shen et al. 2008).

\section{The Americas}

We have not found any study with our search criteria which has reported the presence of HBCDDs or PBBs in mothers' milk from any nation in the Americas.

\section{PFOS}

Thirteen studies report PFOS concentrations in mothers' milk from a total of 13 countries in Asia and Europe and one study from the USA (Table 12). The concentration of PFOS ranges between 39 and $200 \mathrm{pg} / \mathrm{mL}$, with Hungary as the only exception, $330 \mathrm{pg} / \mathrm{mL}$ (Volkel et al. 2008). Due to the limited data, it is not possible to draw any conclusions regarding spatial exposure differences. The spatial distribution of PFOS is illustrated in the diagram in Fig. 10.

Endosulfan

Only some scattered endosulfan mothers' milk data are available (Table 13). The sum concentrations from India and Turkey are exceptionally high, i.e., concentrations above $1000 \mathrm{ng} / \mathrm{g}$ fat (Cok et al. 2011; Sanghi et al. 2003). These high levels are comparable to some data on DDT in mothers' milk (cf. Table 2) and are likely due to the very recent use of endosulfan in these countries.

\section{Chlordecone}

No studies were found with our search criteria reporting chlordecone concentrations in mothers' milk.

\section{SCCPs}

No studies were found with our search criteria reporting SCCP concentrations in mothers' milk, even though there is an 
Table 9 Concentrations (ng/g fat) of aldrin, dieldrin, endrin, and $\sum$ drins, in mothers' milk, as reported in studies from around the world, 1995-2011, are presented

\begin{tabular}{|c|c|c|c|c|c|c|c|c|c|c|}
\hline \multirow[t]{2}{*}{ Region } & \multirow[t]{2}{*}{ Country } & \multicolumn{2}{|l|}{ Aldrin } & \multicolumn{3}{|l|}{ Dieldrin } & \multicolumn{2}{|l|}{ Endrin } & \multirow{2}{*}{$\frac{\sum \text { drins }}{\text { Mean }}$} & \multirow[t]{2}{*}{ Reference } \\
\hline & & Mean & Median & Mean & Median & Geo. mean & Mean & Median & & \\
\hline \multirow[t]{7}{*}{ Africa } & Africa & & & & 2.8 & & & & & UNEP (2011) \\
\hline & Ghana & & & 120 & & & & & & Ntow et al. (2008) \\
\hline & Ghana & & & 1.3 & & & & & & UNEP (2009) \\
\hline & Nigeria & & & 4.1 & & & & & & UNEP (2009) \\
\hline & Senegal & & & 3.1 & & & & & & UNEP (2009) \\
\hline & Tunisia & & & 25 & & & & & & Ennaceur et al. (2008) \\
\hline & Tunisia & & & 59 & 36 & & & & & Ennaceur et al. (2007) \\
\hline \multirow{16}{*}{$\begin{array}{l}\text { Asia and the } \\
\text { Pacific } \\
\text { region }\end{array}$} & Asia and the Pacific & & & & 1.8 & & & & & UNEP (2011) \\
\hline & Australia & & & 51 & 40 & & & & & Khanjani and Sim (2006) \\
\hline & Australia & $0.01-0.68$ & & 15 & & & & & & Harden et al. (2007) \\
\hline & Australia & 0.19 & 0.05 & 16 & 14 & & & & & Mueller et al. (2008) \\
\hline & Australia & & & & $25^{\mathrm{a}}$ & & & & & Noakes et al. (2006) \\
\hline & Australia & & & $150 ; 160$ & & & & & & Quinsey et al. (1995) \\
\hline & Australia & & & & 39 & & & & & Sim et al. (1998) \\
\hline & China & & & $9300-10,000^{\mathrm{a}}$ & & & & & & Wang et al. (2008) \\
\hline & China & & & & & & & & 7.9 & Zhou et al. (2011) \\
\hline & China and Hong Kong & & & 1.1 & & & & & & Hedley et al. (2010) \\
\hline & India & $250^{\mathrm{a}}$ & & & & & & & & Siddiqui et al. (2002) \\
\hline & Japan & & & 28 & & & & & & Konishi et al. (2001) \\
\hline & Japan & & & & 3 & & & & & Nagayama et al. (2007a) \\
\hline & Jordan & 860 & & 1400 & & & & 3300 & & Nasir et al. (1998) \\
\hline & Korea & & & 1.3 & & & & & & UNEP (2009) \\
\hline & Kuwait & 5.2 & & 4.2 & & & 4.0 & & & Saeed et al. (2000) \\
\hline \multirow[t]{13}{*}{ Europe } & $\begin{array}{l}\text { Central and Eastern } \\
\text { Europe }\end{array}$ & & & & 1.6 & & & & & UNEP (2011) \\
\hline & Croatia & 1.3 & & 1.0 & & & 2.0 & 0.7 & & Frkovic et al. (1996) \\
\hline & Denmark & & & & & 5.1 & & & & Shen et al. (2007) \\
\hline & Denmark & & & & 4.9 & & & & & Shen et al. (2008) \\
\hline & Finland & & & & & 2.8 & & & & Shen et al. (2007) \\
\hline & Finland & & & & 2.4 & & & & & Shen et al. (2008) \\
\hline & $\begin{array}{r}\text { Finland and } \\
\text { Denmark }\end{array}$ & & & & 3.6 & & & & & Damgaard et al. (2006) \\
\hline & Germany & & & 14 & & & & & & Schlaud et al. (1995) \\
\hline & Germany & & & $0.018-3.8$ & 4 & & & & & Zietz et al. (2008) \\
\hline & Germany & & & 4 & 2 & & & & & Raab et al. (2008) \\
\hline & Great Britain & & & 48 & 25 & & & & & Harris et al. (1999) \\
\hline & Netherlands & & & & 50 & & & & & Albers et al. (1996) \\
\hline & $\begin{array}{l}\text { Western Europe and } \\
\text { other States }\end{array}$ & & & & 2.5 & & & & & UNEP (2011) \\
\hline \multirow[t]{7}{*}{ The Americas } & $\begin{array}{l}\text { Antigua and } \\
\text { Barbuda }\end{array}$ & & & 2.6 & & & & & & UNEP (2009) \\
\hline & Brazil & & & 23 & & & & & & Paumgartten et al. (2000) \\
\hline & Canada & & & 11 & 1.1 & & & & & $\begin{array}{l}\text { Newsome and Ryan } \\
\text { (1999) }\end{array}$ \\
\hline & Canada & & & 9.8 & 8.5 & & & & & Newsome et al. (1995) \\
\hline & Canada & & & & & 30 & & & & Dewailly et al. (2000) \\
\hline & Chile & & & 5.0 & & & & & & UNEP (2009) \\
\hline & & & & & 4.9 & & & & & UNEP (2011) \\
\hline
\end{tabular}


Table 9 (continued)

\begin{tabular}{|c|c|c|c|c|c|c|c|c|c|c|}
\hline \multirow[t]{2}{*}{ Region } & \multirow[t]{2}{*}{ Country } & \multicolumn{2}{|c|}{ Aldrin } & \multicolumn{3}{|c|}{ Dieldrin } & \multicolumn{2}{|l|}{ Endrin } & \multirow{2}{*}{$\frac{\sum \text { drins }}{\text { Mean }}$} & \multirow[t]{2}{*}{ Reference } \\
\hline & & Mean & Median & Mean & Median & Geo. mean & Mean & Median & & \\
\hline & \multicolumn{10}{|c|}{$\begin{array}{l}\text { Group of Latin } \\
\text { America and } \\
\text { Caribbean countries }\end{array}$} \\
\hline & Mexico & & & & $30-50$ & & & & & Elvia et al. (2000) \\
\hline & Mexico & 280 & & 300 & & & 290 & & & Rodas-Ortiz et al. (2008) \\
\hline & Nicaragua & & & 18 & & & 3.0 & & & Romero et al. (2000) \\
\hline & Uruguay & & & 4.9 & & & & & & UNEP (2009) \\
\hline
\end{tabular}

When concentrations from more than one sampling site in the same country and study have been reported, the concentrations are given as two values separated by a semicolon ";" (two concentrations) or a dash "-" (for more than two concentrations)

${ }^{a}$ Recalculated from fresh weight, assuming $4 \%$ fat content

Table 10 Concentrations (ng/g fat) of pentachlorobenzene (PCBz), toxaphene, and mirex, in mothers' milk, as reported in studies from around the world, 1995-2011, are presented

\begin{tabular}{|c|c|c|c|c|c|c|c|c|c|c|}
\hline \multirow[t]{2}{*}{ Region } & \multirow[t]{2}{*}{ Country } & \multicolumn{3}{|l|}{$\mathrm{PCBz}$} & \multicolumn{2}{|c|}{$\sum$ Toxaphene } & \multicolumn{3}{|l|}{ Mirex } & \multirow[t]{2}{*}{ Reference } \\
\hline & & Mean & Median & Geo. mean & Mean & Median & Mean & Median & Geo. mean & \\
\hline Africa & Nigeria & & & & 4.1 & & & & & UNEP (2009) \\
\hline \multirow{5}{*}{$\begin{array}{l}\text { Asia and the } \\
\text { Pacific region }\end{array}$} & Australia & & & & & & & 0.21 & & Harden et al. (2007) \\
\hline & Australia & & & & & & & 0.18 & & Mueller et al. (2008) \\
\hline & China & & & & & & & 2.4 & & Zhou et al. (2011) \\
\hline & $\begin{array}{l}\text { Hong Kong and } \\
\text { South China }\end{array}$ & & & & 0.8 & & & & & Hedley et al. (2010) \\
\hline & Korea & & & & & 0.8 & & & & UNEP (2009) \\
\hline \multirow[t]{8}{*}{ Europe } & Denmark & & & 0.36 & & & 0.23 & & & Shen et al. (2007) \\
\hline & Denmark & & 0.32 & & & & & 0.21 & & Shen et al. (2008) \\
\hline & Finland & & & 0.27 & & & 0.31 & & & Shen et al. (2007) \\
\hline & Finland & & 0.25 & & & & & 0.26 & & Shen et al. (2008) \\
\hline & Finland and Denmark & & 0.28 & & & & & 0.22 & & Damgaard et al. (2006) \\
\hline & Germany & & & & 16 & & & & & Skopp et al. (2002) \\
\hline & Norway & & & & & & & & & Polder et al. (2008b) \\
\hline & Russia & & & & $10 ; 20$ & $10 ; 19$ & $0.5 ; 0.8$ & $0.5 ; 0.7$ & & Polder et al. (2008a) \\
\hline \multirow[t]{11}{*}{ The Americas } & Antigua and Barbuda & & & & 1.3 & & & & & UNEP (2009) \\
\hline & Canada & & & & & & & & 14 & Dewailly et al. (2000) \\
\hline & Canada & & & & & & & & 3.0 & Fitzgerald et al. (2001) \\
\hline & Canada & 1.0 & 0.91 & & 68 & 56 & 2.3 & 1.8 & & Newsome and Ryan (1999) \\
\hline & Canada & $1.5^{\mathrm{a}}$ & $1.2^{\mathrm{a}}$ & & & & $1.9^{\mathrm{a}}$ & $1.6^{\mathrm{a}}$ & & Newsome et al. (1995) \\
\hline & Mexico & & & & & & 200 & & & Rodas-Ortiz et al. (2008) \\
\hline & Uruguay & & & & & & 9.8 & & & UNEP (2009) \\
\hline & USA & & & & & & & $1.0-5.8$ & & $\begin{array}{l}\text { Madden and Makarewicz } \\
\text { (1996) }\end{array}$ \\
\hline & USA & & & & & & & & 1.4 & Fitzgerald et al. (2001) \\
\hline & USA & & & & & & & 2.4 & & Greizerstein et al. (1999) \\
\hline & USA & & & & & & 4.8 & & & Kostyniak et al. (1999) \\
\hline
\end{tabular}

When concentrations from more than one sampling site in the same country and study have been reported, the concentrations are given as two values separated by a semicolon ";" (two concentrations)

${ }^{a}$ Recalculated from fresh weight, assuming $4 \%$ fat content 
Table 11 Concentrations (ng/g fat) of HBCDD and PBB, in mothers' milk, as reported in studies from around the world, 1995-2011, are presented

\begin{tabular}{|c|c|c|c|c|c|c|c|c|c|c|c|}
\hline \multirow[t]{2}{*}{ Region } & \multirow[t]{2}{*}{ Country } & \multicolumn{2}{|l|}{$\alpha-\mathrm{HBCDD}$} & \multicolumn{2}{|l|}{$\beta$-HBCDD } & \multicolumn{2}{|l|}{$\gamma$-HBCDD } & \multicolumn{2}{|l|}{$\sum \mathrm{HBCDD}$} & \multirow{2}{*}{$\frac{\sum \text { PBB }}{\text { Mean }}$} & \multirow[t]{2}{*}{ Reference } \\
\hline & & Mean & Median & Mean & Median & Mean & Median & Mean & Median & & \\
\hline \multirow[t]{2}{*}{ Africa } & Ghana & $0.29-0.79$ & $0.23-0.62$ & 0.010 & & & & $0.30-0.80$ & $0.27-0.62$ & & Asante et al. (2011) \\
\hline & $\begin{array}{l}\text { South } \\
\text { Africa }\end{array}$ & & & & & & & 0.55 & 0.34 & & $\begin{array}{l}\text { Darnerud et al. } \\
\text { (2011) }\end{array}$ \\
\hline \multirow[t]{4}{*}{ Asia } & China & $0.33-2.8$ & & & & 0.46 & & $0.33-2.8$ & & & Shi et al. (2009) \\
\hline & Japan & 1.4 & & & & & & 1.4 & & & $\begin{array}{l}\text { Kakimoto et al. } \\
\text { (2008) }\end{array}$ \\
\hline & Philippines & $0.58 ; 0.72$ & $0.50 ; 0.67$ & $0.052 ; 0.18$ & $0.043 ; 0.12$ & $0.14 ; 0.48$ & $0.13 ; 0.23$ & $0.81 ; 1.0$ & $0.52 ; 0.89$ & & $\begin{array}{l}\text { Malarvannan et al. } \\
\text { (2009) }\end{array}$ \\
\hline & Vietnam & & $0.33 ; 0.38$ & & & & & & $0.33 ; 0.38$ & & Tue et al. (2010) \\
\hline \multirow[t]{11}{*}{ Europe } & Denmark & & & & & & & & & 0.26 & Shen et al. (2008) \\
\hline & Finland & & & & & & & & & 0.17 & Shen et al. (2008) \\
\hline & Norway & & & & & & & 1.7 & 0.86 & & $\begin{array}{l}\text { Thomsen et al. } \\
\text { (2010) }\end{array}$ \\
\hline & Russia & & & & & & & $0.47 ; 0.71$ & $0.45 ; 062$ & & Polder et al. (2008a) \\
\hline & Spain & 14 & 4.4 & & & 40 & 23 & 47 & 27 & & Eljarrat et al. (2009) \\
\hline & Sweden & & & & & & & 0.45 & 0.30 & & Aune et al. (2002) \\
\hline & Sweden & & & & & & & $0.63^{\mathrm{a}} ; 0.80^{\mathrm{a}}$ & $0.58^{\mathrm{a}}$ & & Bergman et al. (2010) \\
\hline & Sweden & & & & & & & 0.39 & & & $\begin{array}{l}\text { Fängström et al. } \\
\text { (2008) }\end{array}$ \\
\hline & Sweden & & & & & & & & $0.3-0.4$ & & Glynn et al. (2011) \\
\hline & Sweden & & & & & & & 0.42 & 0.35 & & Lignell et al. (2003) \\
\hline & UK & 4.9 & 3.2 & 0.32 & 0.30 & 0.49 & 0.50 & 6.0 & 3.8 & & $\begin{array}{l}\text { Abdallah and Harrad } \\
\text { (2011) }\end{array}$ \\
\hline
\end{tabular}

When concentrations from more than one sampling site in the same country and study have been reported, the concentrations are given as two values separated by a semicolon ";" (two concentrations) or a dash "-" (for more than two concentrations)

${ }^{a}$ Quantified using BDE-139 as surrogate standard

Fig. 9 Graphical presentation of HBCDD concentrations in mothers' milk from countries worldwide

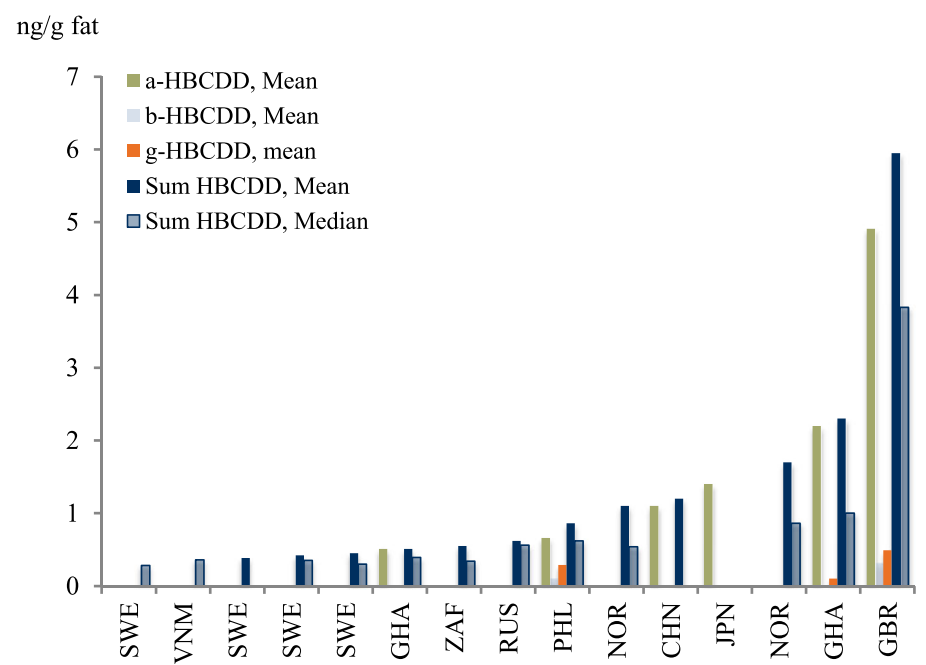

$\mathrm{ng} / \mathrm{g}$ fat

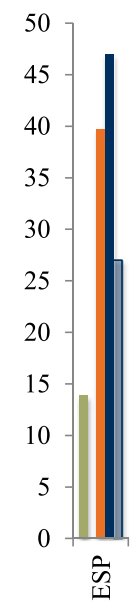


Table 12 PFOS concentrations in mothers' milk, expressed in picograms per milliliter of milk as reported in studies from around the world, 19952011, are presented

\begin{tabular}{|c|c|c|c|c|}
\hline Region & Country & Mean $(\mathrm{pg} / \mathrm{mL})$ & Median $(\mathrm{pg} / \mathrm{mL})$ & Reference \\
\hline \multirow[t]{10}{*}{ Asia and the Pacific } & Cambodia & 67 & 40 & Tao et al. (2008a) \\
\hline & China & $6-140$ & & Liu et al. (2010) \\
\hline & China & 120 & 100 & So et al. (2006) \\
\hline & India & 46 & 39 & Tao et al. (2008a) \\
\hline & Indonesia & 84 & 67 & Tao et al. (2008a) \\
\hline & Japan & 230 & 200 & Tao et al. (2008a) \\
\hline & Malaysia & 120 & 110 & Tao et al. (2008a) \\
\hline & Philippines & 98 & 100 & Tao et al. (2008a) \\
\hline & South Korea & 61 & & Kim et al. (2011a) \\
\hline & Vietnam & 76 & 59 & Tao et al. (2008a) \\
\hline \multirow[t]{8}{*}{ Europe } & Germany & $120 ; 130$ & $110 ; 120$ & Volkel et al. (2008) \\
\hline & Germany & 40 & & Fromme et al. (2010) \\
\hline & Hungary & 310 & 330 & Volkel et al. (2008) \\
\hline & Spain & 120 & 110 & Kärrman et al. (2010) \\
\hline & Spain & 120 & & Llorca et al. (2010) \\
\hline & Sweden & $120-260$ & 170 & Kärrman et al. (2007) \\
\hline & Sweden & 120 & & Kärrman et al. (2006) \\
\hline & Sweden & 75 & & Sundström et al. (2011) \\
\hline The Americas & USA & 130 & 110 & Tao et al. (2008a) \\
\hline
\end{tabular}

When concentrations from more than one sampling site in the same country and study have been reported, the concentrations are given as two values separated by a semicolon ";" (two concentrations) or a dash "-" (for more than two concentrations)

agency report on SCCPs in Swedish mothers' milk (Darnerud et al. 2012) indicating their presence in this matrix.

\section{Global distribution trends}

The data collected and compiled within the study indicates that there is indeed a difference in the distribution and exposure to POPs which is dependent on where in the world one resides. These conclusions are more easily made when comparing the different spatial distribution diagrams, e.g., Fig. 3. In general, it was found that DDT/DDE pesticides were reported in higher concentrations in mothers' milk from the regions of Africa, Asia, and Central America, with a propensity for agricultural economies and lower degree of
Fig. 10 Graphical presentation of PFOS concentrations in mothers' milk from countries worldwide

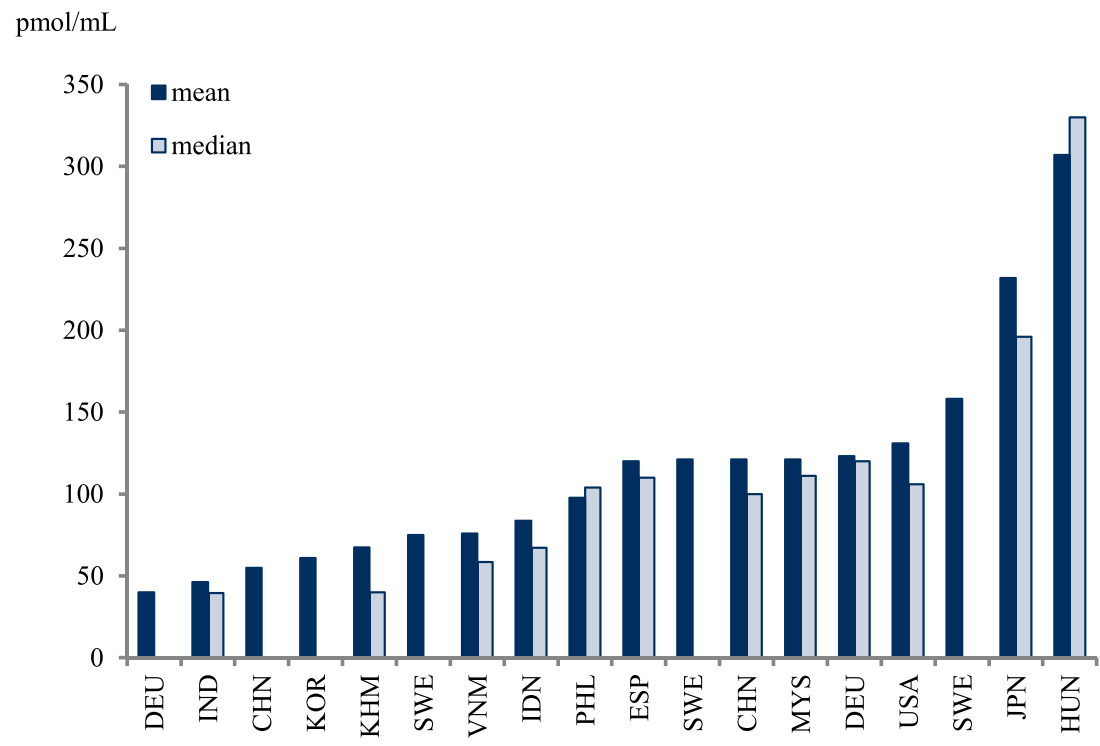


Table 13 Concentrations (ng/g fat) of endosulfan, in mothers' milk, as reported in studies from around the world, 1995-2011, are presented

\begin{tabular}{|c|c|c|c|c|c|c|c|c|c|c|}
\hline \multirow[t]{2}{*}{ Region } & \multirow[t]{2}{*}{ Country } & \multicolumn{2}{|c|}{$\alpha$-Endosulfan } & \multicolumn{2}{|c|}{$\beta$-Endosulfan } & \multicolumn{2}{|c|}{$\sum$ Endosulfan } & \multicolumn{2}{|c|}{ Endosulfan sulfate } & \multirow[t]{2}{*}{ Reference } \\
\hline & & Mean & Median & Mean & Median & Mean & Median & Mean & Median & \\
\hline Africa & Egypt & & 4.8 & & & & & & & Saleh et al. (1996) \\
\hline \multirow[t]{2}{*}{ Asia } & India & & & & & $9100^{\mathrm{a}, \mathrm{b}}$ & & & & Sanghi et al. (2003) \\
\hline & Turkey & $50^{\mathrm{a}}$ & & $950^{\mathrm{a}}$ & & $1000^{\mathrm{a}}$ & & & & Cok et al. (2011) \\
\hline \multirow[t]{6}{*}{ Europe } & Spain & $17^{\mathrm{a}}$ & $22^{\mathrm{a}}$ & $270^{\mathrm{a}}$ & $180^{\mathrm{a}}$ & $280^{\mathrm{a}}$ & $200^{\mathrm{a}}$ & $150^{\mathrm{a}}$ & $120^{\mathrm{a}}$ & Cerrillo et al. (2005) \\
\hline & Denmark & 7.4 & & & & & & & & Shen et al. (2007) \\
\hline & Denmark & & 7.4 & & & & & & & Shen et al. (2008) \\
\hline & $\begin{array}{l}\text { Denmark } \\
\text { and Finland }\end{array}$ & & 6.8 & & & & & & & $\begin{array}{l}\text { Damgaard et al. } \\
\text { (2006) }\end{array}$ \\
\hline & Finland & 7.3 & & & & & & & & Shen et al. (2007) \\
\hline & Finland & & 6.4 & & & & & & & Shen et al. (2008) \\
\hline The Americas & Mexico & & & 280 & & & & & & $\begin{array}{l}\text { Rodas-Ortiz et al. } \\
\text { (2008) }\end{array}$ \\
\hline
\end{tabular}

When concentrations from more than one sampling site in the same country and study have been reported, the concentrations are given as two values separated by a semicolon ";" (two concentrations) or a dash "-" (for more than two concentrations)

${ }^{a}$ Recalculated from fresh weight, assuming $4 \%$ fat content

${ }^{\mathrm{b}}$ Nonspecified isomer/s

industrialization. On the other hand, PCBs and dioxins were found to be reported to a higher degree in more industrialized regions, such as parts of Asia, Europe, and North America. A good example of this can be seen by comparing Figs. 3 and $4 \mathrm{a}-\mathrm{c}$, where the DDT/DDE concentrations clearly are lower, in general, in Europe and North America compared to the rest of the world (Fig. 3). Similarly, it can be seen from Fig. 4a-c that the PCB concentrations are higher in industrialized regions compared to the rest of the world. This pattern is also observed for HCHs, although there are a few observations of high concentrations in mothers' milk samples from Eastern Europe, i.e., Russia, Romania, and Ukraine (Fig. 6a-d).This pattern is not surprising since PCBs and dioxins, not shown in spatial distribution diagrams, are related to a degree of industrialization, either as chemical products or impurities there within. DDT as well as HCHs has been used as pesticides in $\mathrm{SC}$ and has been used in the equatorial and subequatorial regions, which in general are less industrialized and more dependent on agriculture. Furthermore, it is clear that mothers' milk from the USA contains more PBDEs than the rest of the world (Fig. 7). BDE-47 is a biomarker of PBDE exposure and the lowest reported concentration is around five times as big as the highest concentration in a sample from outside of the USA. This can be explained by the stricter flame retardant policy enforced within the USA, a policy which calls for a greater use of flame retardant substances such as PBDEs primarily in upholstery (GSPI 2013; State of California 2000, 2013). A new fire safety regulation has recently been adopted, January 1st 2014, which does not call for the use of flame retardant chemicals and perhaps this will lead to a decrease of PBDEs in mothers' milk in the USA (GSPI 2013; State of California 2000, 2013). For the substances not mentioned, there are no observed, clear spatial distribution trends that can be explained by traditional/ historical use of the substances in question. This could be since there are too few reported concentrations available or that the differences in use or emissions are too small to observe.

\section{Temporal trends}

Two distinct objectives can be identified concerning temporal trend monitoring of contaminants. One is to quantitatively estimate the rate of changes in contaminant concentration, e.g., as a change in percent per year or as half- or doubling time in number of years. An example of this could be to estimate the response of measures taken to reduce the discharges of various contaminants. Dissimilarities in comparisons between the rate of change in contaminant concentration in mothers' milk and other environmental biological matrices (e.g., fish) can give information about the exposure patterns, i.e., if the mothers are exposed to contaminants not only from local food but also from imported food and the indoor environment, including a variety of man-made technical products. Another objective of temporal trend monitoring is to study emerging new substances and to detect renewed use of banned contaminants. In order to estimate the rate quantitatively with a high statistical power, it is essential to keep the random variation between years as low as possible. Compared to other matrices, 
mothers' milk seems to show a relatively low random variation (UNEP 2004).

Inclusion of a time series in this review article requires a minimum of five reported data points. Only approximately half of the substance groups from only two countries, Sweden and Japan, fulfilled the described criteria. The temporal trends present data from 1972 to 2011.

In the graphs below, log-linear regression and a smoother test have been carried out. The smoother test checks if the smoother explains significantly more of the variation in concentration, than the regression line (Nicholson et al. 1998). The regression line and/or the smoother are plotted when significant $(\alpha=0.05)$.

\section{DDT and DDT-related compounds}

In Fig. 11, the concentrations of DDE (ng/g fat) in the samples from Japan, 1972-1998 (Konishi et al. 2001), and Sweden, 1972-2010 (Athanasiadou and Bergman 2008; Bergman et al. 2010; Lundén and Norén 1998), show significant decreasing trends over the whole time period of $-9.1 \%(p<0.001)$ and $-8.5 \%(p<0.001)$, respectively. The Japanese samples also show significant decreasing concentrations for the last 10 years of $-13 \%(p<0.001)$, while no trend is indicated in the Swedish samples for the last 10 years (estimated during a decade later than for the Japanese samples). The temporal trends for DDT in mothers' milk from Japan and Sweden are of similar magnitude as for DDE. In addition, the trends observed in
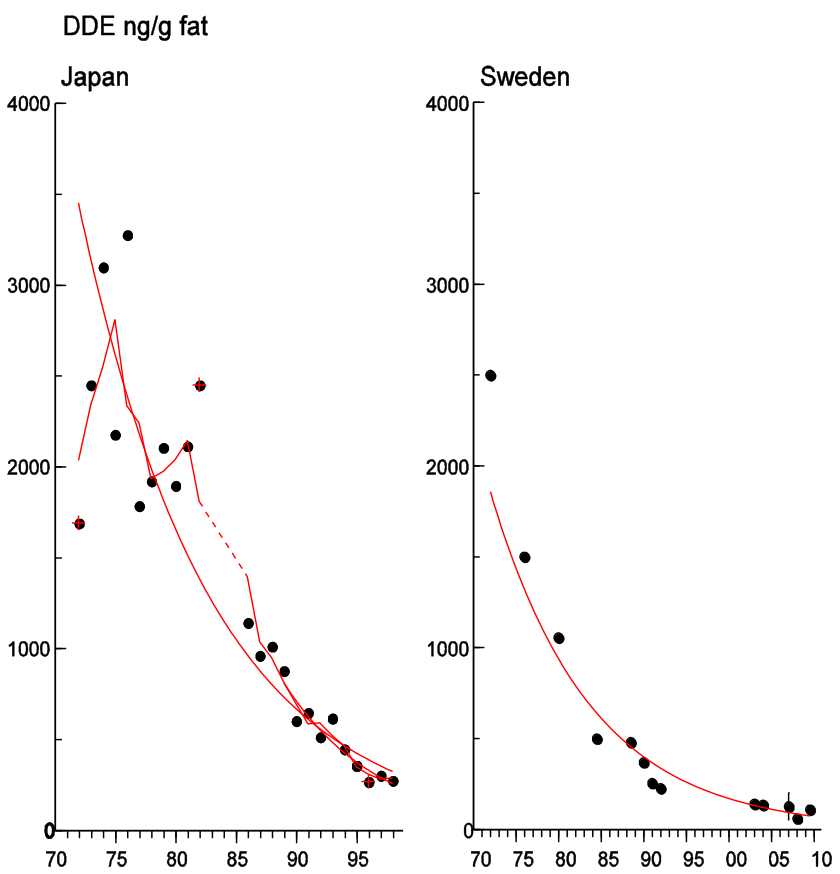

Fig. 11 Temporal trends of DDE (ng/g fat) from Japan (Konishi et al. 2001) and Sweden (Lundén and Norén 1998; Athanasiadou and Bergman 2008; Bergman et al. 2010)

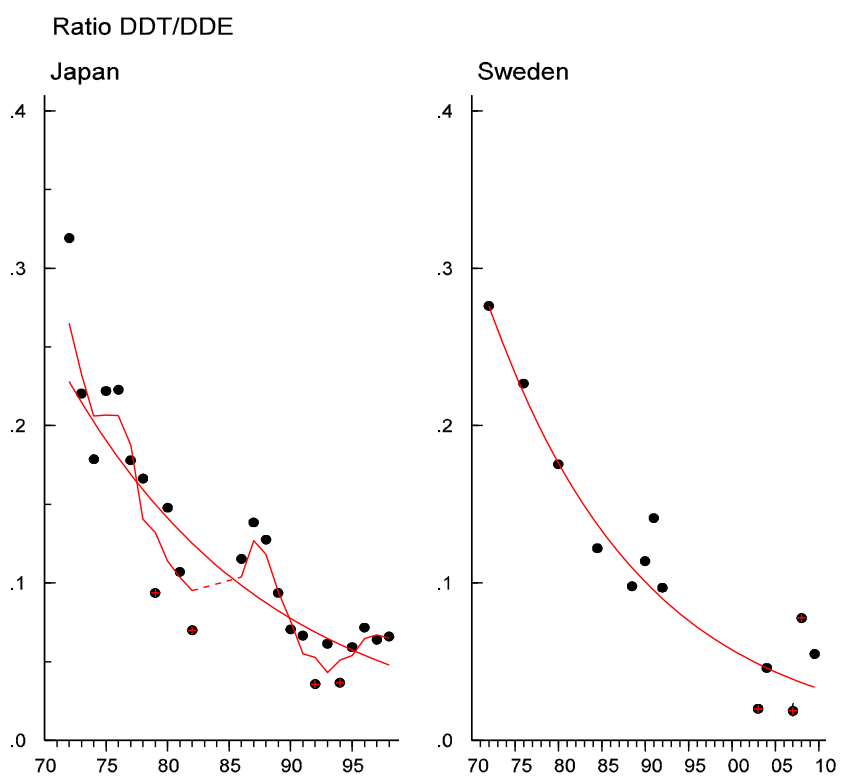

Fig. 12 Temporal trends of the ratio between DDT and DDE (ng/g fat) from Japan (Konishi et al. 2001) and Sweden (Lundén and Norén 1998; Athanasiadou and Bergman 2008; Bergman et al. 2010)

Swedish mothers' milk for DDE coincide with the trends seen in Swedish freshwater (Nyberg et al. 2011) and marine (Bignert et al. 2012) biota.

The ratio of DDT/DDE (Fig. 12) shows similar log-linear trends in the samples from Japan, 1972-1998 (Konishi et al. 2001), and Sweden, 1972-2010 (Athanasiadou and Bergman 2008; Bergman et al. 2010; Lundén and Norén 1998). The Japanese samples also show a significant nonlinear trend for the ratio of DDT/DDE, which might indicate that a new release of DDT has occurred during the monitoring period.

\section{PCBs}

In Fig. 13, the concentrations of $\sum$ PCB (ng/g fat) in the samples from Japan, 1972-1998 (Konishi et al. 2001), and Sweden, 1972-2010 (Athanasiadou and Bergman 2008; Bergman et al. 2010; Lundén and Norén 1998), show significant decreasing trends over the whole time period of $-7.5 \%$ $(p<0.001)$ and $-6.5 \%(p<0.001)$, respectively, and for the last 10 years of $-7 \%(p<0.001)$ and $-11 \%(p<0.011)$, respectively. The trends observed in Swedish mothers' milk for $\sum$ PCB coincide with the trends seen in Swedish freshwater (Nyberg et al. 2011) and marine (Bignert et al. 2012) biota.

Only one temporal trend study on congener basis was found for PCBs within this review (from Sweden). In Fig. 14, the temporal trend for CB-153 (ng/g fat) in the Swedish samples, 1972-2010 (Bergman et al. 2010; Lundén and Norén 1998), is presented. CB-153 shows a significant decreasing trend over the whole time period and for the last 10 years of $-4.9 \%$ $(p<0.001)$ and $-5.9 \%(p<0.042)$, respectively. 

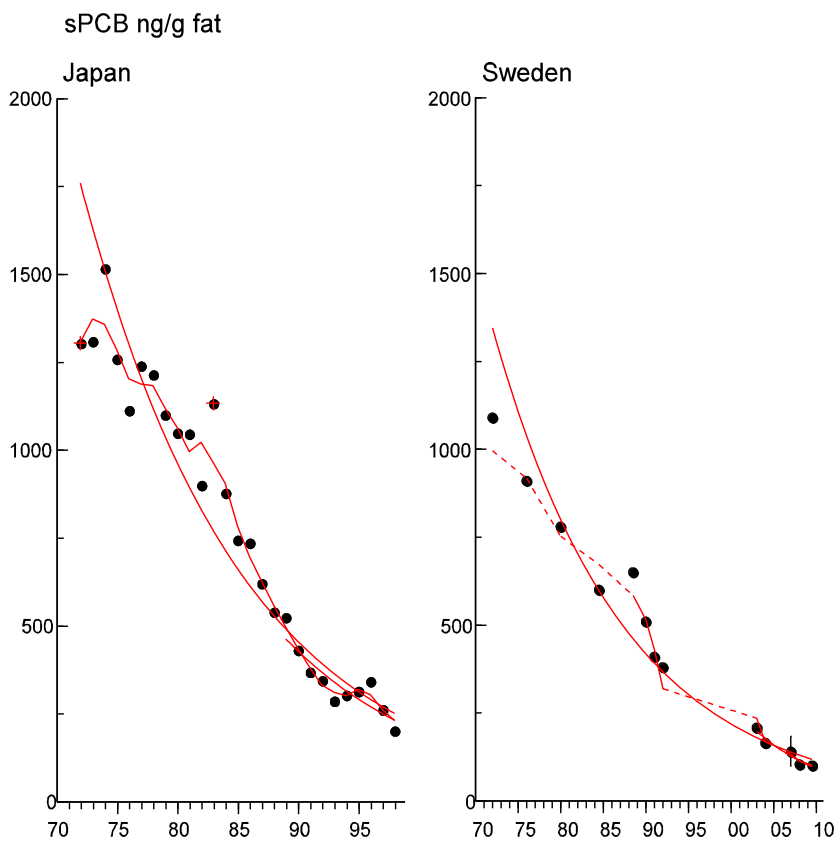

Fig. 13 Temporal trends of $\Sigma$ PCB (ng/g fat) from Japan (Konishi et al. 2001) and Sweden (Lundén and Norén 1998; Athanasiadou and Bergman 2008; Bergman et al. 2010)

\section{$\mathrm{HCB}$ and $\mathrm{HCHs}$}

In Fig. 15 , the concentrations of $\beta-\mathrm{HCH}$ (ng/g fat) in the samples from Japan, 1972-1998 (Konishi et al. 2001), show a significant decreasing trend over the whole time period as well as for the last 10 years of $-12 \%(p<0.001)$ and $-11 \%$ $(p<0.001)$, respectively.

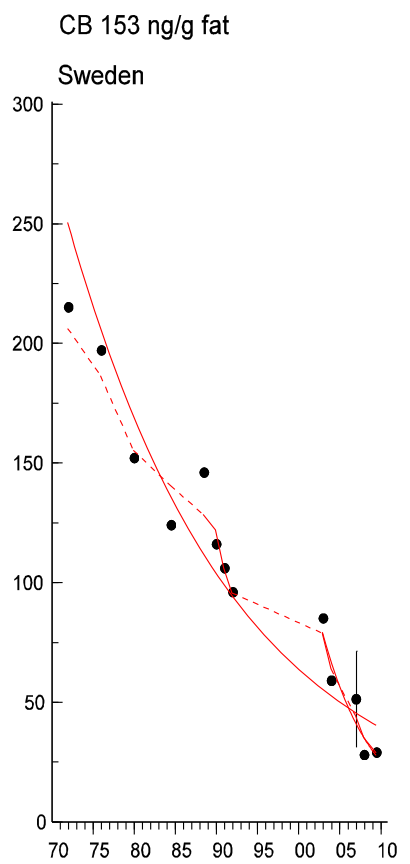

Fig. 14 Temporal trend of CB-153 (ng/g fat) from Sweden (Lundén and Norén 1998; Athanasiadou and Bergman 2008; Bergman et al. 2010)

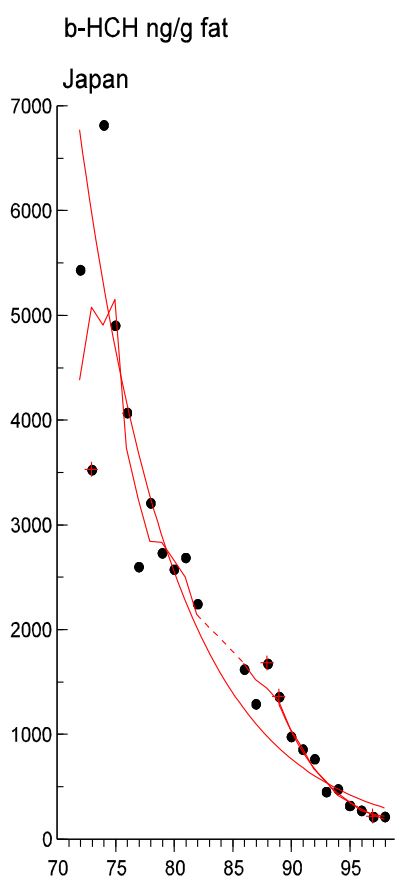

Fig. 15 Temporal trends of $\beta-\mathrm{HCH}$ (ng/g fat) from Japan (Konishi et al. 2001)

PCDDs, PCDFs, and DL-PCBs

In Fig. 16, the concentrations of PCDD (pg $\mathrm{WHO}_{2005}-\mathrm{TEQ} / \mathrm{g}$ fat) from Stockholm, 1972-1997 (Norén and Meironyte 2000) and 1972-2011 (Fång et al. 2013), show significant decreasing trends over the whole time period of $-3.6 \%(p<0.005)$ and $-6.0 \%(p<0.001)$, respectively. However, for the last

\section{PCDD pg WHO05-TEQ/g fat}
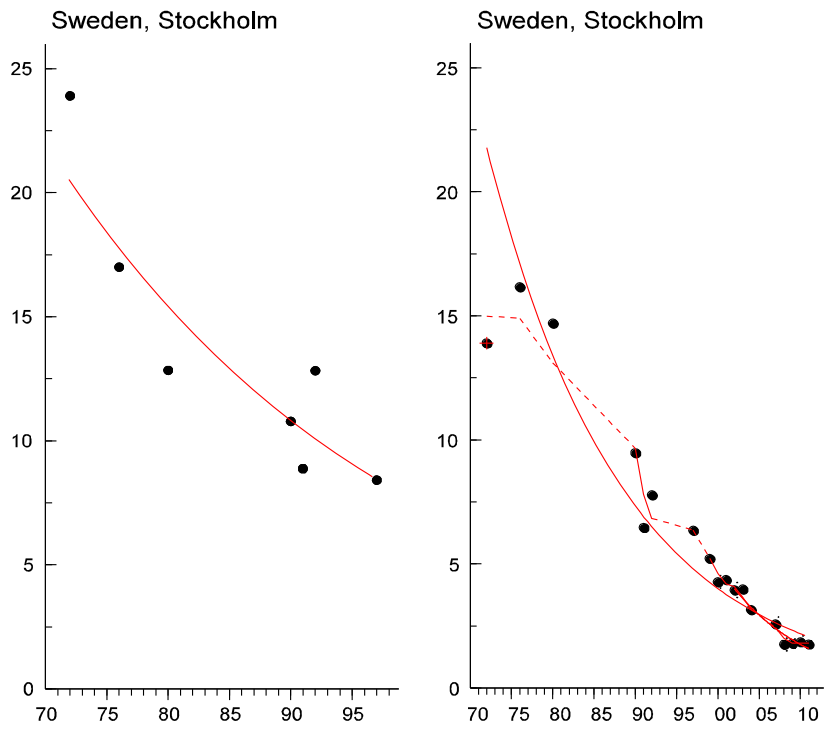

Fig. 16 Two temporal trends of PCDD in $\mathrm{WHO}_{2005}$-TEQ (pg/g fat) from Sweden, on the left (Norén and Meironyte 2000) and on the right (Fång et al. 2013) 
10 years, a significant decreasing trend of $-10 \%(p<0.001)$ is only seen for the time series from 1972 to 2011 (Fång et al. 2013), covering the last decade in contrast to the study from 1972 to 1997 (Norén and Meironyte 2000), which might have too few samples during the last 10 years to detect a trend. It should be noted that the two studies by Norén and Meironyte and the study by Fång et al. are analyzing the same pooled mothers' milk sample during 1972-1997.

In Fig. 17, the concentrations of PCDF (pg WHO $2005-\mathrm{TEQ} /$ $\mathrm{g}$ fat) from Stockholm, 1972-1997 (Konishi et al. 2001; Norén and Meironyte 2000) and 1972-2011 (Fång et al. 2013), show significant decreasing trends over the whole time period of $-5.2 \%(p<0.003)$ and $-6.2 \%(p<0.001)$, respectively. However, for the last 10 years, a significant decreasing trend of $-7.3 \%(p<0.001)$ is only seen for the time series from 1972 to 2011 (Fång et al. 2013), covering the last decade in contrast to the study from 1972 to 1997 (Norén and Meironyte 2000), which might have too few samples during the last 10 years (only 4 ) to detect a trend.

In Fig. 18, the concentrations of DL-PCBs (pg $\mathrm{WHO}_{2005^{-}}$ TEQ/g fat) from Stockholm, 1972-1997 (Norén and Meironyte 2000) and 1972-2011 (Fång et al. 2013), show significant decreasing trends over the whole time period of $-5.1 \%(p<0.001)$ and $-7.0 \%(p<0.001)$, respectively. For the last 10 years, a significant decreasing trend of $-12 \%$ $(p<0.012)$ is seen for the samples from 1972 to 2011 (Fång et al. 2013), and a decreasing trend of $-6.7 \%(p<0.107)$ is also indicated in the samples from 1972 to 1997 (Norén and Meironyte 2000).

\section{PCDF pg WHO05-TEQ/g fat}
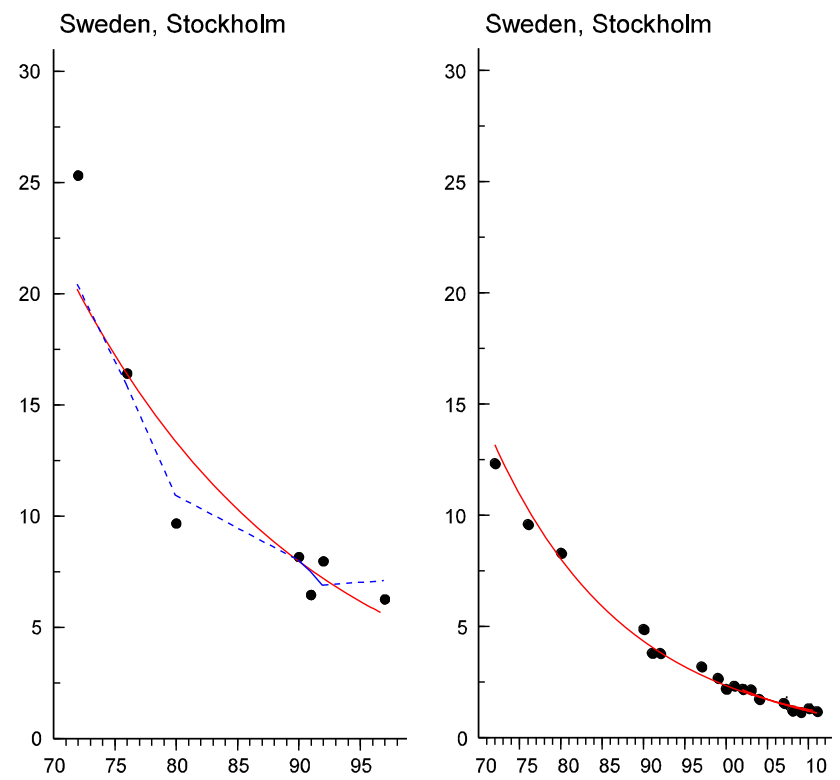

Fig. 17 Two temporal trends of PCDF in WHO2005-TEQ (pg/g fat) from Sweden, on the left (Norén and Meironyte 2000) and on the right (Fång et al. 2013)
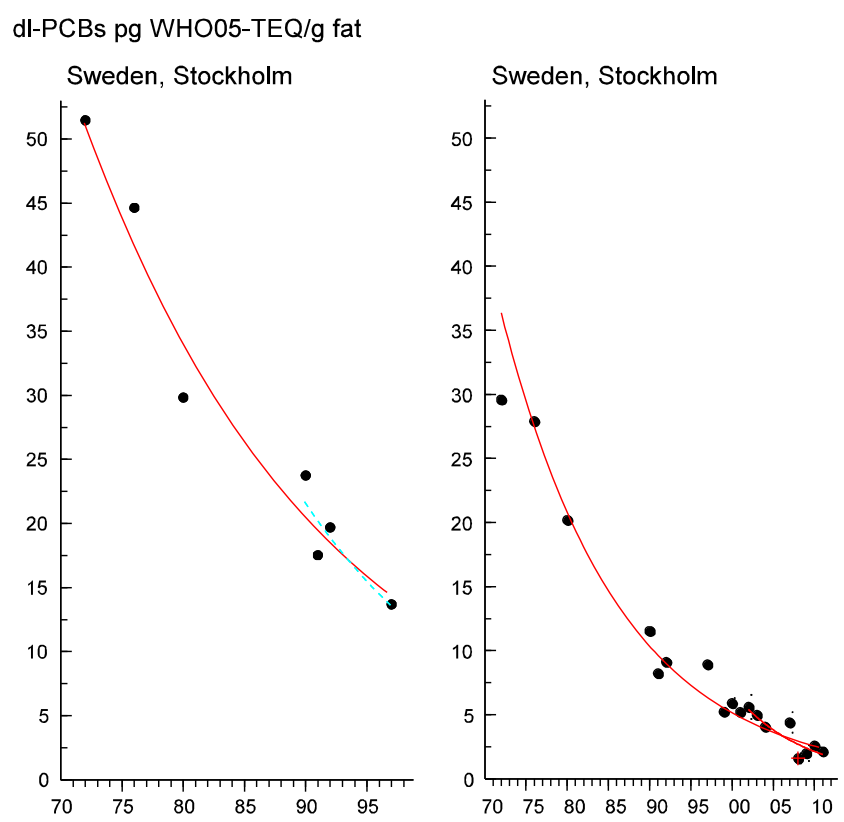

Fig. 18 Two temporal trends of dioxin-like PCBs (DL-PCBs) in $\mathrm{WHO}_{2005}$-TEQ (pg/g fat) from Sweden, on the left (Norén and Meironyte 2000) and on the right (Fång et al. 2013)

The trends observed in Swedish mothers' milk for DLPCBs during the whole time period coincide with the trends seen in Swedish freshwater (Nyberg et al. 2011) and marine (Bignert et al. 2012) biota for the dioxin-like PCB congener CB-118 from the end of the 1970s to the beginning of the 1990s. However, during the last decade, the levels are decreasing at a higher rate in Swedish human milk than in marine and freshwater biota from Sweden.

\section{PBDEs}

In Fig. 19, the concentrations of BDE-47 (ng/g fat) in the samples from Japan, 1977-1999 (Akutsu et al. 2003), indicate an increasing trend over the whole time period of $9.1 \%$ $(p<0.081)$. In contrast, a decreasing trend of $-5.7 \%$ $(p<0.093)$ is indicated in the Swedish samples from Stockholm (Athanasiadou and Bergman 2008; Bergman et al. 2010; Fängström et al. 2008) for the last 10 years of the study. This decreasing trend of BDE-47 coincides with the trends seen in Swedish marine (Bignert et al. 2012) and freshwater (Nyberg et al. 2011) biota over the last decade. PentaBDE was first phased out voluntarily by the industry in Germany in 1986 and end in Sweden in 1999 (Alcock and Busby 2006). Subsequently, BDE-47 was partially banned within the EU countries in 2004 and the declining concentrations in human milk and biota could to some extent be explained by these events. No trend could be observed in the Swedish time trend from Uppsala during 1996-2001 (Lind et al. 2003). 
Fig. 19 Temporal trends of BDE-47 (ng/g fat) from Japan (Akutsu et al. 2003) and from Stockholm (Athanasiadou and Bergman 2008; Fängström et al. 2008; Bergman et al. 2010) and Uppsala (Lind et al. 2003), Sweden
BDE-47 $\mathrm{ng} / \mathrm{g}$ fat

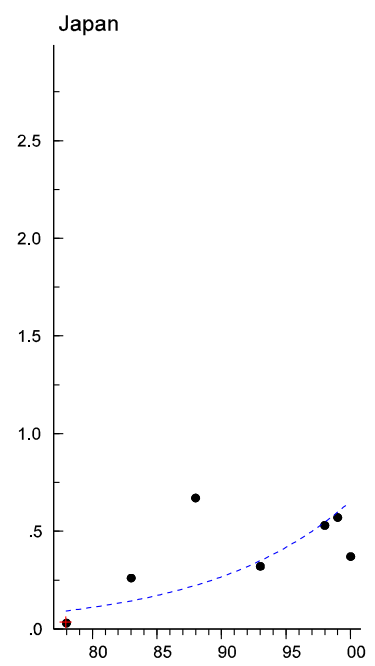

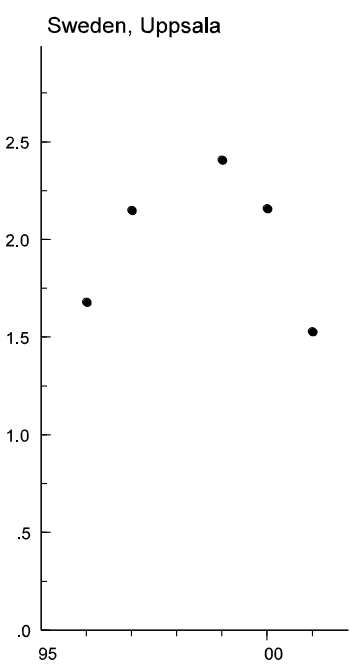

\section{Heptachlor}

In Fig. 20, the concentrations of heptachlorepoxide (ng/g fat) in the samples from Japan, 1986-1998 (Konishi et al. 2001), show significant decreasing trends over the whole time period and for the last 10 years of $-9.7 \%(p<0.001)$ and $-4.9 \%$ $(p<0.049)$, respectively.

Dieldrin, endrin, and aldrin

In Fig. 21, the concentrations of dieldrin (ng/g fat) in the samples from Japan, 1972-1982 (Konishi et al. 2001), show a significant decreasing trend over the whole time period of $-14 \%(p<0.001)$.

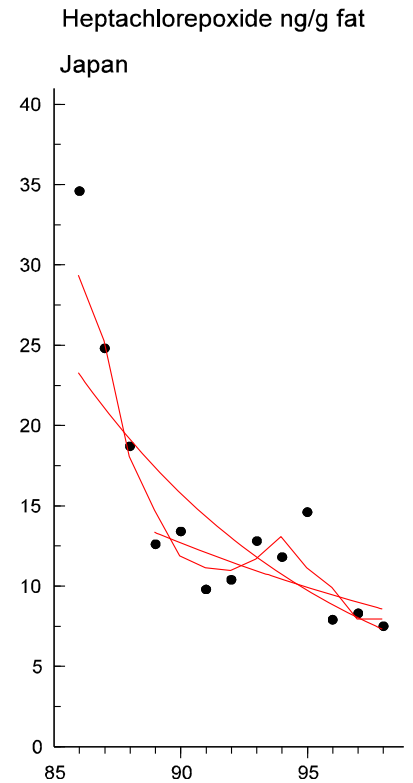

Fig. 20 Temporal trend of heptachlorepoxide (ng/g fat) from Japan (Konishi et al. 2001)

\section{HBCDD}

The concentrations in Fig. 22 of HBCDD (ng/g fat) in the samples from Japan, 1987-2007 (Kakimoto et al. 2008) and Sweden, 1987-2010 (Athanasiadou and Bergman 2008; Bergman et al. 2010; Fängström et al. 2008), show increasing trends over the whole time period of $5.4 \%$ per year $(p<0.061)$ and $7.6 \%$ per year $(p<0.001)$, respectively. The increasing trend of HBCDD seen in the Swedish milk samples coincides with trends in Swedish marine biota from the Baltic Sea (Bignert et al. 2012). HBCDD is still in use within the EU but is listed in REACHs authorization list as substance of very high concern (SVHC) and, since November 2014, included in the SC.

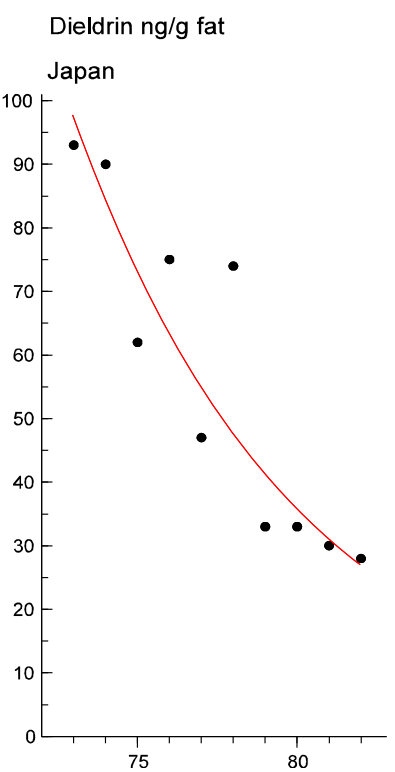

Fig. 21 Temporal trend of dieldrin (ng/g fat) from Japan (Konishi et al. 2001) 


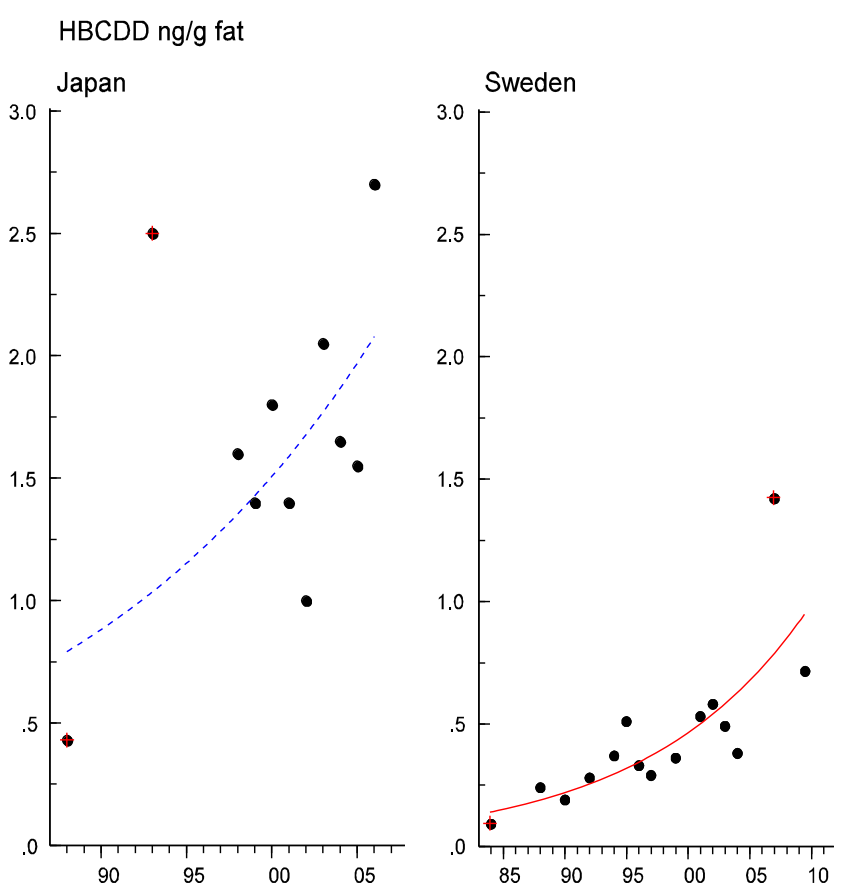

Fig. 22 Temporal trends of HBCDD (ng/g fat) from Japan (Kakimoto et al. 2008) and Sweden (Athanasiadou and Bergman 2008; Fängström et al. 2008; Bergman et al. 2010)

\section{PFOS}

In Fig. 23, the concentrations of PFOS (pg/ml) in the samples from Stockholm, 1972-2008 (Sundström et al. 2011), show a significant increasing trend over the whole time period of $3.3 \%(p<0.012)$. In contrast, a significant decreasing trend of $-11 \%(p<0.002)$ is observed for the last 10 years. In the

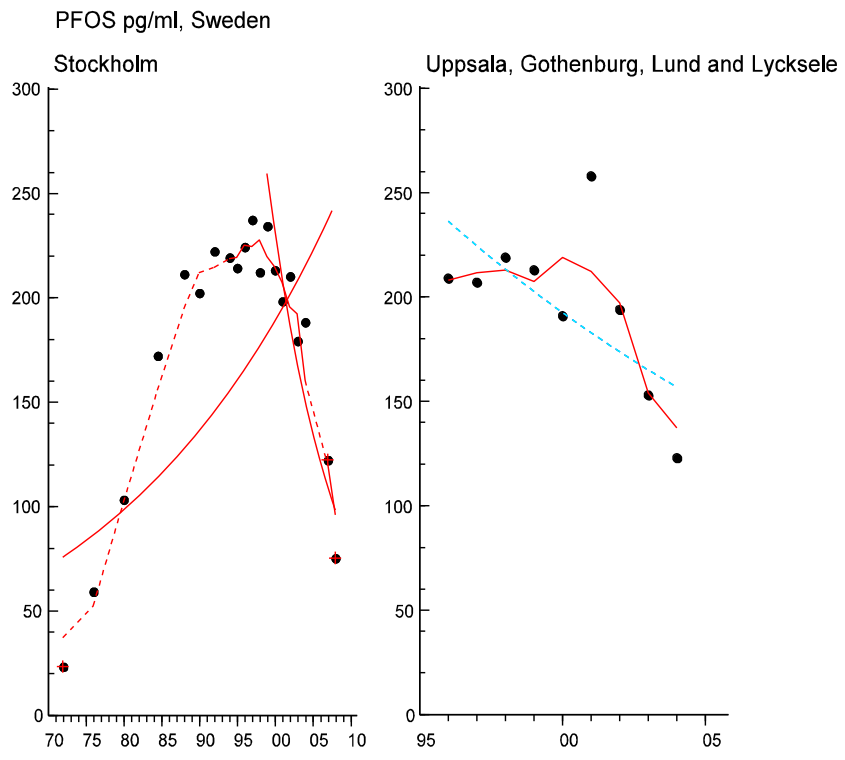

Fig. 23 Two temporal trends of PFOS (pg/mL) from Stockholm (Sundström et al. 2011) and Uppsala, Gothenburg, Lund and Lycksele (Kärrman et al. 2007), Sweden study with samples from Uppsala, Gothenburg, Lund, and Lycksele, 1996-2004 (Kärrman et al. 2007), a decreasing trend is indicated $(p<0.059)$ for the whole time period. The trends observed in Swedish mothers' milk for PFOS coincide with the trends seen in Swedish marine (Bignert et al. 2012) and freshwater (Nyberg et al. 2011) biota over the last decade.

\section{Critical remarks and conclusions}

Some of the legacy POPs are the most well-researched environment pollutants among all. This is due to their global distribution and occurrence in humans and wildlife, being classified as CMRs, having endocrine disruption effects and/or having other toxic effects. Some early efforts focused on the transfer of these chemically stable and bioaccumulative compounds to nursing children. The transfer of POPs via mothers' milk initiated a still ongoing debate on risks for the newborn babies. In contrast to the strict recommendations to nursing mothers to avoid smoking and drinking alcohol, it is not possible to change the mothers' body burdens of POPs as their levels of these compounds have been built up over the mothers' whole lifetime. However, in some countries, there are at least dietary recommendations on how to limit the intake of POPs from some major food sources, in particular fatty fish. These recommendations are primarily targeting young women and women in child-bearing ages. Due to the many positive effects of nursing, WHO recommends mothers to breast feed their newborns for a minimum of 6 months (WHO and UNICEF 2014).

WHO also initiated a monitoring program for POPs in mothers' milk in 1976 (WHO 2009), but at this point, researchers had already started to do exposure studies of nursing infants, as reviewed by Norén and Meironyte (2000). In the present review, it becomes clear how abundant mothers' milk is a matrix for POP analysis, although only a limited number of POPs are assessed, i.e., 7 of the 24 (HCHs counted individually) POPs in Table 1 contribute with $80 \%$ of the exposure studies discussed herein. There are no studies covering all, or even a majority of the POPs in the same study. The most comprehensive results for POP exposure analyses are when the same milk samples are utilized for assessments of as many POPs as possible. In reality, it is much more common with scattered studies globally, regionally and country-wise. This means that the cohorts are defined by different means and the objectives vary. This leads to the conclusion that there are very few studies that allow reliable comparisons, e.g., the temporal trend studies from Japan and Sweden. However, the temporal trend studies from Japan and Sweden presented did not cover POP analyses in an optimal manner, i.e., several of the POPs were not included in these studies. Another issue regarding 
comprehensive time trend analysis is the need to establish environmental specimen banks whose goal is to collect and store environmental relevant samples, including mothers' milk, in a structured manner. In time, samples collected will allow a high qualitative time trend analysis on current POPs and currently unknown pollutants. Further, this is only the start of the problem comparing POPs in mothers' milk from around the world. Below, we list and shortly discuss some of the major shortcomings in some studies which, if rectified, would allow proper comparisons of POPs in mothers' milk.

Reporting base for POP concentrations in mothers' milk This is relevant for all POPs that are produced, used, and/or occur as mixtures of halogenated homologues and isomers-congeners. These POPs are PCBs, PCDFs, PCDDs, PBDEs, PBBs, chlordanes, toxaphen, and CPs. HCHs may be included even though only isomers of hexachlorinated cyclohexane is included. Similarly, HBCDD has three diastereomers $(\alpha-, \beta-$, and $\gamma$-HBCDD), which are commonly discussed and often reported individually. DDTs and endosulfan, on the other hand, are both produced as two main isomers. However, both 4,4'-DDT and 2,4'-DDT are transformed to and occur in the environment, including mothers' milk, as the corresponding DDD and DDE compounds. This has led to a similar handling of the DDTs as of true congeners of, e.g., PCBs. For all of these compounds/compound classes, it is common to report concentration sums (e.g., sPCB or $\sum$ PCB), sometimes indicating how many $\mathrm{PCB}$ congeners are included in the sum and presented as $\sum \mathrm{PCB}(7)$, indicating that seven congeners were included. However, highly variable sums are reported for the POPs. For PCBs, for example, a number of different sum values have been found in the review including $3,4,6,7,8$, $12,15,16,19,32$, and 35 PCB congeners. Sometimes, the reported sum concentrations are referred to as "total PCBs" without any further specification. However, it is clear that it is still a summation of a defined number of PCB congeners, i.e., those quantified. To further complicate the issue, PCBs can also be reported as DL-PCBs and non-DL-PCBs or as non-ortho-PCBs, mono-ortho-PCBs, and di-orthoPCBs. Hence, it is realistically not possible to compare $\sum$ PCB concentrations unless they are reported in a similar manner. In this review article, we have used $\sum$ PCB data but these are the weakest, the most unreliable, while the $\sum \mathrm{PCB}(6)$ and $\mathrm{CB}-153$ concentration data are comparable if reported similarly by other means (mean, median, fat or fresh weight basis, cf. below).

The concentration reports for PBDEs follow a similar pattern as for the PCBs, often reporting $\sum$ PBDEs but with differences in number and identity of PBDE congeners. Still, we have chosen to show $\sum$ PBDE levels in Table 7, but for the purpose of comparison, BDE-47 and BDE-209 are recommended for use. The reporting variability applies for all POPs that have isomers and congeners and for which individual reference standards for analysis are available. The latter allows congener-, or isomer-, specific analysis, but the complexity of data generated call for simplifications.

Two classes of POPs, DDTs and dioxins, require further attention regarding concentration reports. The DDTs are commonly reported as the sum of 4,4'-DDT and its metabolites, 4, 4'-DDE (major transformation product) and 4,4'-DDD. However, the $\sum$ DDT may also include the true isomers, 2,4'DDT and 4,4'-DDT or even the two isomers plus their metabolites. Concentrations of the abundant compounds 4,4'-DDT, $4,4^{\prime}$-DDE, and 4,4'-DDD are however quite frequently reported. This allows proper comparisons of the concentrations and to calculate comparable ratios of DDT versus either DDE or DDE and DDD, which can be done using different methods. In Table 2, we have applied the ratio 4,4'-DDT/4,4'-DDE due to the abundance of individual concentration data for these two pollutants.

The reporting of dioxin concentrations is another problem, even though individual concentration data are generated from the chemical analyses. The actual concentrations of dioxins (PCDDs, PCDFs, and DL-PCBs) are commonly reported as sum of their TEQs, after recalculation of the concentrations utilizing the TEF values - the most commonly used nowadays are the WHO TEFs from 1998 and 2005 (Van den Berg et al. 1998, 2006). However, if the $\sum$ PCDDs, $\sum$ PCDFs, and $\sum$ DLPCBs, or worse $\sum$ dioxins, are presented, it is strongly limiting any comparisons, unless the actual concentration data of the individual congeners are presented as well.

In conclusion, POPs in mothers' milk, as well as in other matrices, must be reported on a congener- or isomer-specific basis to promote proper trend studies. Unfortunately, this is not done in a structured manner today, which is strongly hampering the comparisons in the present data set on POPs in mothers' milk.

Concentration base for POPs in mothers' milk The most common way of reporting concentrations of POPs in human matrices and wildlife is on weight basis, i.e., microgram, nanogram, picogram per weight of the matrix (gram or kilogram), or on volume (e.g., $\mathrm{mL}$ ) of the matrix, which relates to a fresh weight, volume, or extracted lipids/fats. The concentrations are rarely reported on a molar base (e.g., $\mathrm{nmol} / \mathrm{g}$ or $\mathrm{pmol} / \mathrm{g}$ ). Despite the fact that this is the correct way of assessing exposures used for risk assessments and for correct comparisons, this means reporting is only found in very few studies of POPs in mothers' milk. This problem is particularly evident for the polybrominated pollutants, where the molecular weight varies greatly between the different congeners. The implications are shown in Fig. 24, where it is clear that the "number of molecules" (molar base) of CB-153 is 2.5 times the number of BDE-209, although the masses of the two are equal. Since there is such an extensive span in molecular 


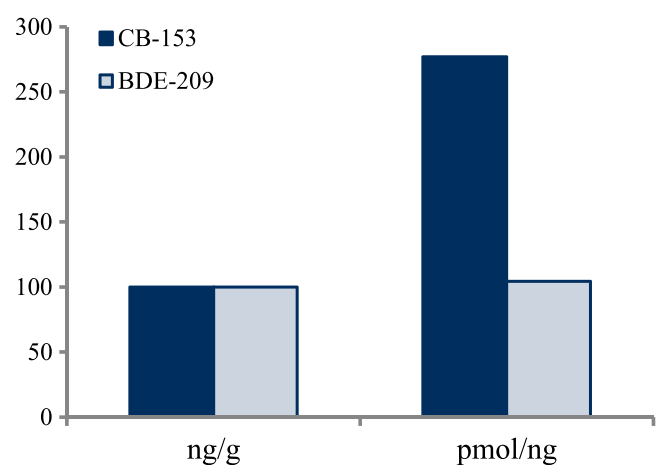

Fig. 24 Comparison between CB-153 and BDE-209 on a weight (ng/g) and molar (pmol/g) basis

masses among the POPs, it is crucial that this must be considered for future studies/reports on POPs.

Another obstacle for comparisons of POPs in mothers' milk is how to handle more water-soluble POPs, e.g., PFOS, other perfluorinated compounds, and organohalogen phenols. PFOS is commonly reported on a fresh weight basis, i.e., picograms per milliliter, while other POPs are reported on a fat weight basis (e.g., $\mathrm{ng} / \mathrm{g}$ fat). To allow conversions, it is necessary to know the fat content of the matrix analyzed.

In conclusion, a change from weight- to molar-based reporting on POPs is needed in order to avoid unnecessary errors in exposure assessments and to allow accurate trend analyses. Furthermore, the fresh weight of mothers' milk samples as well as concentrations on fat weight basis, and vice versa, should be mandatory since this would facilitate comparisons between studies.

Reporting The reported measure of central tendency of the concentrations of POPs is not consistent, i.e., the arithmetic mean, the geometric mean, or median values, and sometimes, only a range is given without a mean or a median. This hampers the possibilities to compare data. However, if a lognormal distribution can be assumed, which is common for contaminant data (see, e.g., Esmen and Hammad 1977), the geometric mean and the median can be considered equal. The arithmetic mean is, with the same assumption of log-normality, always higher than the median. Some guidance of how to adjust for this bias is given by Caudill $(2010,2012)$. In conclusion, commonly agreed upon guidelines for this part in reporting exposure data are also required.

Overall conclusions Unfortunately, reporting of POPs in mothers' milk differs greatly between the studies. This has limited the comparisons for both spatial and temporal trend studies.

Acknowledgments The financial support from the Swedish EPA is acknowledged for enabling this work.
Open Access This article is distributed under the terms of the Creative Commons Attribution License which permits any use, distribution, and reproduction in any medium, provided the original author(s) and the source are credited.

\section{References}

Abballe A et al (2008) Persistent environmental contaminants in human milk: concentrations and time trends in Italy. Chemosphere 73: S220-S227. doi:10.1016/j.chemosphere.2007.12.036

Abdallah MA, Harrad S (2011) Tetrabromobisphenol-A, hexabromocyclododecane and its degradation products in UK human milk: relationship to external exposure. Environ Int 37:443448. doi:10.1016/j.envint.2010.11.008

Akutsu K, Hori S (2004) Polybrominated diphenyl ether flame retardants in foodstuffs and human milk. J Food Hyg Soc Jpn 45:175-183

Akutsu K, Kitagawa M, Nakazawa H, Makino T, Iwazaki K, Oda H, Hori S (2003) Time-trend (1973-2000) of polybrominated diphenyl ethers in Japanese mother's milk. Chemosphere 53: 645-654

Alaluusua $\mathrm{S}$ et al (2002) Natal and neonatal teeth in relation to environmental toxicants. Pediatr Res 52:652-655. doi:10.1203/01.pdr. 0000031926.09665.f1

Alawi MA, Fayyad MK, Al-Aqqad S (2006) Persistent organic pollutants (POPs) in Jordanian human milk. Fresenius Environ Bull 15:118124

Albers JMC, Kreis IA, Liem AKD, vanZoonen P (1996) Factors that influence the level of contamination of human milk with polychlorinated organic compounds. Arch Environ Contam Toxicol 30:285-291

Alcock RE, Busby J (2006) Risk migration and scientific advance: the case of flame-retardant compounds. Risk Anal 26:369-381. doi:10. 1111/j.1539-6924.2006.00739.x

Alivernini S, Battistelli CL, Turrio-Baldassarri L (2011) Human Milk as a Vector and an Indicator of Exposure to PCBs and PBDEs: Temporal Trend of Samples Collected in Rome. Bull Environ Contam Toxicol 87:21-25. doi:10.1007/s00128-011-0262-7

Al-Saleh I, Al-Zahrani M, Al-Shanshoury M, Mohammed G, Shinwari N, Al-Doush I, Basile P (2002) Comparative quantitative study of DDT and its metabolites in human milk by gas chromatography with electron capture and mass spectrometric detection. Chromatographia 55:457-461

Al-Saleh I, Shinwari N, Basile P, El-Doush I, Al-Zahrani M, AlShanshoury M, Mohammed GED (2003) DDT and its metabolites in breast milk from two regions in Saudi Arabia. J Occup Environ Med 45:410-427. doi:10.1097/01.jom.0000058344.05741.22

Antignac JP et al (2008) Exposure assessment of fetus and newborn to brominated flame retardants in France: preliminary data. Mol Nutr Food Res 52:258-265. doi:10.1002/mnfr.200700077

Asante KA et al (2011) Human exposure to PCBs, PBDEs and HBCDs in Ghana: temporal variation, sources of exposure and estimation of daily intakes by infants. Environ Int 37:921-928. doi:10.1016/j. envint.2011.03.011

Ataniyazova OA, Baumann RA, Liem AKD, Mukhopadhyay UA, Vogelaar EF, Boersma ER (2001) Levels of certain metals, organochlorine pesticides and dioxins in cord blood, maternal blood, human milk and some commonly used nutrients in the surroundings of the Aral Sea (Karakalpakstan, Republic of Uzbekistan). Acta Paediatr 90:801-808

Athanasiadou M, Bergman $\AA$ (2008) Insamling av bröstmjölksprover från Stockholm, Göteborg, Lund och Umeå samt Analyser av insamlade bröstmjölksprover, Resultat från 2007 års arbete. 
Department of Environmental Chemistry, Stockholm University, Stockholm

ATSDR (1995) Toxicological profile for mirex and chlordecone. U.S. Department of Health and Human Services

ATSDR (1996) Public health statement for endrin

ATSDR (2000) Toxicological profile for polychlorinated biphenyls (PCBs)

ATSDR (2005) Toxicological profile for alpha-, beta-, gamma- and deltahexachlorocyclohexane. U.S. Department of Health and Human Services

ATSDR (2010) Toxicological profile for toxaphene

Atuma SS, Hansson L, Johnsson H, Slorach S, de Wit CA, Lindstrom G (1998) Organochlorine pesticides, polychlorinated biphenyls and dioxins in human milk from Swedish mothers. Food Addit Contam 15:142-150

Aune M, Barregård L, Claesson A, Darnerud PO (2002) Resultatrapport till Miljöövervakningen: Organiska miljögifter i bröstmjölk från Göteborg 2001. Livsmedelsverket, Stockholm

Azeredo A et al (2008) DDT and its metabolites in breast milk from the Madeira River basin in the Amazon, Brazil. Chemosphere 73:S246S251. doi:10.1016/j.chemosphere.2007.04.090

Bake MA, Linnika Z, Sudmalis P, Kocan A, Jursa S, Pike A, Ruce M (2007) Assessment of the exposure of breast milk to persistent organic pollutants in Latvia. Int J Hyg Environ Health 210:483-489. doi:10.1016/j.ijheh.2007.01.016

Banerjee BD, Zaidi SSA, Pasha ST, Rawat DS, Koner BC, Hussain QZ (1997) Levels of HCH residues in human milk samples from Delhi, India. Bull Environ Contam Toxicol 59:403-406

Becher C, Skaare JU, Polder A, Sletten B, Rossland OJ, Hansen HK, Ptashekas J (1995) PCDDS, PCDFS, and PCBS in human-milk from different parts of Norway and Lithuania. J Toxicol Environ Health 46:133-148

Behrooz RD, Sari AE, Bahramifar N, Ghasempouri SM (2009) Organochlorine pesticide and polychlorinated biphenyl residues in human milk from the Southern Coast of Caspian Sea, Iran. Chemosphere 74:931-937. doi:10.1016/j.chemosphere.2008.10.014

Bencko V, Skulova Z, Krecmerova M, Liem AKD (1998) Selected polyhalogenated hydrocarbons in breast milk. Toxicol Lett 96-7: 341-345

Bergman $\AA$ et al (2010) Insamling och kemisk analys av miljöföroreningar i svensk modersmjölk - Resultat från 20082010. Department of Materials and Environmental Chemistry, Stockholm University, Stockholm

Bignert A et al. (2012) Comments Concerning the National Swedish Contaminant Monitoring Programme in Marine Biota. 7:2010. Swedish Museum of Natural History

Bordajandi LR, Abad E, Gonzalez MJ (2008) Occurrence of PCBs, $\mathrm{PCDD} / \mathrm{Fs}$, PBDEs and DDTs in Spanish breast milk: enantiomeric fraction of chiral PCBs. Chemosphere 70:567-575. doi:10.1016/j. chemosphere.2007.07.019

Bouwman H, Sereda B, Meinhardt HM (2006) Simultaneous presence of DDT and pyrethroid residues in human breast milk from a malaria endemic area in South Africa. Environ Pollut 144:902-917. doi:10. 1016/j.envpol.2006.02.002

Brucker-Davis F et al (2010) Exposure to selected endocrine disruptors and neonatal outcome of 86 healthy boys from Nice area (France). Chemosphere 81:169-176

Brunetto R, Leon A, Burguera JL, Burguera M (1996) Levels of DDT residues in human milk of Venezuelan women from various rural populations. Sci Total Environ 186:203-207

Burke ER, Holden AJ, Shaw IC (2003) A method to determine residue levels of persistent organochlorine pesticides in human milk from Indonesian women. Chemosphere 50:529-535

Cajka T, Hajslova J (2003) Polychlorinated biphenyls and organochlorine pesticides in human milk from the locality Prague,
Czech Republic: a comparative study. Bull Environ Contam Toxicol 70:913-919

Caudill SP (2010) Characterizing populations of individuals using pooled samples. J Expo Sci Environ Epidemiol 20:29-37. doi:10.1038/jes. 2008.72

Caudill SP (2012) Use of pooled samples from the national health and nutrition examination survey. Stat Med 31:3269-3277. doi:10.1002/ $\operatorname{sim} .5341$

CDC (2013) Fourth national report on human exposure to environmental chemicals: updated tables

Cerna M, Bencko V, Brabec M, Smid J, Krskova A, Jech L (2010) Exposure assessment of breast-fed infants in the Czech Republic to indicator PCBs and selected chlorinated pesticides: area-related differences. Chemosphere 78:160-168. doi:10.1016/j.chemosphere. 2009.09.062

Cerrillo I et al (2005) Endosulfan and its metabolites in fertile women, placenta, cord blood, and human milk. Environ Res 98:233-239. doi:10.1016/j.envres.2004.08.008

Chan JKY et al (2007) Body loadings and health risk assessment of polychlorinated dibenzo-p-dioxins and dibenzofurans at an intensive electronic waste recycling site in China. Environ Sci Technol 41:7668-7674. doi:10.1021/es071492j

Channa K, Roellin HB, Nost TH, Odland JO, Sandanger TM (2012) Prenatal exposure to DDT in malaria endemic region following indoor residual spraying and in non-malaria coastal regions of South Africa. Sci Total Environ 429:183-190. doi:10.1016/j.scitotenv. 2012.03.073

Chao HR, Wang SL, Su PH, Yu HY, Yu ST, Papke O (2005) Levels of polychlorinated dibenzo-p-dioxins and dibenzofurans in primipara breast milk from Taiwan: estimation of dioxins and furans intake for breastfed infants. J Hazard Mater 121:1-10. doi:10.1016/j.jhazmat. 2004.09.021

Chao HR, Wang SL, Lin TC, Chung XH (2006) Levels of organochlorine pesticides in human milk from central Taiwan. Chemosphere 62:1774-1785. doi:10.1016/j.chemosphere. 2005.07.036

Chikuni O, Nhachi CFB, Nyazema NZ, Polder A, Nafstad I, Skaare JU (1997) Assessment of environmental pollution by PCBs, DDT and its metabolites using human milk of mothers in Zimbabwe. Sci Total Environ 199:183-190

Chovancova J, Conka K, Kocan A, Sejakova ZS (2011) PCDD, PCDF, $\mathrm{PCB}$ and PBDE concentrations in breast milk of mothers residing in selected areas of Slovakia. Chemosphere 83:1383-1390. doi:10. 1016/j.chemosphere.2011.02.070

CICAD (2003) Polychlorinated biphenyls: human health aspects. Geneva, Switzerland

Cioroiu M, Tarcau D, Mocanu R, Cucu-Man S, Nechita B, Luca M (2010) Organochlorine pesticides in colostrums in case of normal and preterm labor (IASI, Romania). Sci Total Environ 408:2639-2645

Cok I, Bilgili A, Ozdemir M, Ozbek H, Bilgili N, Burgaz S (1997) Organochlorine pesticide residues in human breast milk from agricultural regions of Turkey, 1995-1996. Bull Environ Contam Toxicol 59:577-582

Cok I, Karakaya AE, Afkham BL, Burgaz S (1999) Organochlorine pesticide contaminants in human milk samples collected in Tebriz (Iran). Bull Environ Contam Toxicol 63:444-450

Cok I, Gorucu E, Satiroglu MH, Demircigil GC (2003) Polychlorinated biphenyl (PCB) levels in human milk samples from Turkish mothers. Bull Environ Contam Toxicol 70:41-45

Cok I, Toprak D, Durmaz TA, Demirkaya E, Kabukcu G (2005) Determination of organochlorine contaminants in human milk collected at Afyon, Turkey. Fresenius Environ Bull 14:503-508

Cok I et al (2009) Polychlorinated dibenzo-p-dioxins, dibenzofurans and polychlorinated biphenyls levels in human breast milk from different regions of Turkey. Chemosphere 76:1563-1571. doi:10.1016/j. chemosphere.2009.05.032 
Cok I, Yelken C, Durmaz E, Uner M, Sever B, Satir F (2011) Polychlorinated biphenyl and organochlorine pesticide levels in human breast milk from the Mediterranean city Antalya, Turkey. Bull Environ Contam Toxicol 86:423-427. doi:10.1007/s00128-0110221-3

Colles A et al (2008) Fourth WHO-coordinated survey of human milk for persistent organic pollutants (POPs): Belgian results. Chemosphere 73:907-914. doi:10.1016/j.chemosphere.2008. 07.002

Covaci A, Hura C, Schepens P (2001) Determination of selected persistent organochlorine pollutants in human milk using solid phase disk extraction and narrow bore capillary GC-MS. Chromatographia 54: $247-252$

Czaja K, Ludwicki JK, Goralczyk K, Strucinski P (1997a) Effect of age and number of deliveries on mean concentration of organochlorine compounds in human breast milk in Poland. Bull Environ Contam Toxicol 59:407-413

Czaja K, Ludwicki JK, Goralczyk K, Strucinski P (1997b) Organochlorine pesticides, HCB, and PCBs in human milk in Poland. Bull Environ Contam Toxicol 58:769-775

Damgaard IN et al (2006) Persistent pesticides in human breast milk and cryptorchidism. Environ Health Perspect 114:1133-1138. doi:10. 1289/ehp.8741

Daniels JL, Pan IJ, Jones R, Anderson S, Patterson DG, Needham LL, Sjödin A (2010) Individual characteristics associated with PBDE levels in US human milk samples. Environ Health Perspect 118: 155-160. doi:10.1289/ehp.0900759

Darko G, Acquaah SO (2008) Levels of organochlorine pesticides residues in dairy products in Kumasi, Ghana. Chemosphere 71:294 298. doi:10.1016/chemosphere.2007.09.005

Darnerud PO (2001) Sakrapport till Miljöövervakningen: Organiska miljögifter i bröstmjölk från Uppsala, 2000-2001. Stockholm

Darnerud PO, Lignell S, Glynn A, Aune M, Törnkvist A, Stridsberg M (2010) POP levels in breast milk and maternal serum and thyroid hormone levels in mother-child pairs from Uppsala, Sweden. Environ Int 36:180-187

Darnerud PO et al (2011) Levels of brominated flame retardants and other persistent organic pollutants in breast milk samples from Limpopo province, South Africa. Sci Total Environ 409:4048-4053. doi:10. 1016/j.scitotenv.2011.05.054

Darnerud P-O, Aune M, Glynn A, Borgen A (2012) Chlorinated paraffins in Swedish breast milk. Sundbyberg, Sweden

Devanathan $G$ et al (2009) Persistent organochlorines in human breast milk from major metropolitan cities in India. Environ Pollut 157: $148-154$

Dewailly E, Ayotte P, Laliberte C, Weber JP, Gingras S, Nantel AJ (1996) Polychlorinated biphenyl (PCB) and dichlorodiphenyl dichloroethylene (DDE) concentrations in the breast milk of women in Quebec. Am J Public Health 86:1241-1246

Dewailly E, Ayotte P, Bruneau S, Gingras S, Belles-Isles M, Roy R (2000) Susceptibility to infections and immune status in Inuit infants exposed to organochlorines. Environ Health Perspect 108:205-211

EFSA (2010) Scientific opinion on polybrominated biphenyls (PBBs) in food. Parma, Italy

EFSA (2011) Scientific opinion on hexabromocyclododecanes (HBCDDs) in food. Parma, Italy. doi:10.2903/j.efsa.2011.2296

EFSA (2012) Scientific opinion on polybrominated diphenyl ethers (PBDEs) in food

Eggesbo M, Stigum H, Polder A, Magnus P (2006) The association between previous breastfeeding and current PCB levels in human milk. Epidemiology 17:S369-S370

Eggesbo M et al (2009) Levels of hexachlorobenzene (HCB) in breast milk in relation to birth weight in a Norwegian cohort. Environ Res 109:559-566. doi:10.1016/j.envres.2009.04.001

Eggesbo M, Thomsen C, Jorgensen JV, Becher G, Odland JO, Longnecker MP (2011) Associations between brominated flame retardants in human milk and thyroid-stimulating hormone (TSH) in neonates. Environ Res 111:737-743. doi:10.1016/j.envres.2011. 05.004

Ejobi F, Kanja LW, Kyule MN, Nyeko J, Opuda-Asibo J (1998) Some factors related to sum-DDT levels in Ugandan mothers' breast milk. Public Health 112:425-427

Elafi A, Rahmani M, Abdennebi EH (2001) Organochlorine pesticide residues in breast milk from women living in Tripoli, Libya. Fresenius Environ Bull 10:349-352

Eljarrat E, Guerra P, Martinez E, Farre M, Alvarez JG, Lopez-Teijon M, Barcelo D (2009) Hexabromocyclododecane in human breast milk: levels and enantiomeric patterns. Environ Sci Technol 43:1940 1946. doi:10.1021/es802919e

Elvia LF, Sioban HD, Bernardo HP, Constanza SC (2000) Organochlorine pesticide exposure in rural and urban areas in Mexico. J Expo Anal Environ Epidemiol 10:394-399

Ennaceur S, Gandoura N, Driss MR (2007) Organochlorine pesticide residues in human milk of mothers living in Northern Tunisia. Bull Environ Contam Toxicol 78:325-329. doi:10.1007/s00128007-9185-8

Ennaceur S, Gandoura N, Driss MR (2008) Distribution of polychlorinated biphenyls and organochlorine pesticides in human breast milk from various locations in Tunisia: levels of contamination, influencing factors, and infant risk assessment. Environ Res 108:86-93. doi:10.1016/j.envres.2008.05.005

Erdogrul O, Covaci A, Kurtul N, Schepens P (2004) Levels of organohalogenated persistent pollutants in human milk from Kahramanmaras region, Turkey. Environ Int 30:659-666. doi:10. 1016/j.envint.2003.12.004

Esmen NA, Hammad YY (1977) Log-normality of environmental sampling data. J Environ Sci Health Part A Environ Sci Eng Toxic Hazard Subst Control 12:29-41

Fång J, Nyberg E, Bignert A, Bergman Å (2013) Temporal trends of polychlorinated dibenzo-p-dioxins and dibenzofurans and dioxinlike polychlorinated biphenyls in mothers' milk from Sweden, 1972-2011. Environ Int 60:224-231. doi:10.1016/j.envint.2013. 08.019

Fängström B, Athanassiadis L, Odsjö T, Norén K, Bergman $\AA$ (2008) Temporal trends of polybrominated diphenyl ethers and hexabromocyclododecane in milk from Stockholm mothers, 1980 2004. Mol Nutr Food Res 52:187-193. doi:10.1002/mnfr. 200700182

Fitzgerald EF, Hwang SA, Bush B, Cook K, Worswick P (1998) Fish consumption and breast milk PCB concentrations among Mohawk women at Akwesasne. Am J Epidemiol 148:164-172

Fitzgerald EF, Hwang SA, Deres DA, Bush B, Cook K, Worswick $\mathrm{P}$ (2001) The association between local fish consumption and DDE, mirex, and HCB concentrations in the breast milk of Mohawk women at Akwesasne. J Expo Anal Environ Epidemiol 11:381-388

Focant JF, Pirard C, Thielen C, De Pauw E (2002) Levels and profiles of PCDDs, PCDFs and cPCBs in Belgian breast milk. Estimation of infant intake. Chemosphere 48:763-770

Frederiksen M, Thomsen C, Froshaug M, Vorkamp K, Thomsen M, Becher G, Knudsen LE (2010) Polybrominated diphenyl ethers in paired samples of maternal and umbilical cord blood plasma and associations with house dust in a Danish cohort. Int J Hyg Environ Health 213:233-242. doi:10.1016/ j.ijheh.2010.04.008

Frkovic A, Zivkovic A, AlebicJuretic A (1996) Organochlorine pesticide residues and polychlorinated biphenyls in human milk from Northern Adriatic Region (Croatia). Fresenius Environ Bull 5:474-481

Fromme $\mathrm{H}$ et al (2010) Pre- and postnatal exposure to perfluorinated compounds (PFCs). Environ Sci Technol 44:7123-7129. doi:10. 1021/es101184f 
Fujii Y et al (2011) Detection of dicofol and related pesticides in human breast milk from China, Korea and Japan. Chemosphere 82:25-31. doi:10.1016/j.chemosphere.2010.10.036

Gladen BC, Monaghan SC, Lukyanova EM, Hulchiy OP, ShkyryakNyzhnyk ZA, Sericano JL, Little RE (1999) Organochlorines in breast milk from two cities in Ukraine. Environ Health Perspect 107:459-462

Gladen BC, Shkiryak-Nyzhnyk ZA, Chyslovska N, Zadorozhnaja TD, Little RE (2003) Persistent organochlorine compounds and birth weight. Ann Epidemiol 13:151-157

Glynn AW, Atuma S, Aune M, Darnerud PO, Cnattingius S (2001) Polychlorinated biphenyl congeners as markers of toxic equivalents of polychlorinated biphenyls, dibenzo-p-dioxins and dibenzofurans in breast milk. Environ Res 86:217-228. doi:10.1006/enrs.2001. 4270

Glynn A, Aune M, Ankarberg E, Lignell S, Darnerud PO (2007) Dioxiner, furaner, polyklorerade bifenyler, klorerade bekämpningsmedel och bromerade flamskyddsmedel i modersmjölk - tidstrend för Uppsala mellan 1996 och 2006. vol Hälsorelaterad miljöövervakning. Livsmedelsverket, Uppsala

Glynn A et al (2011) Regional differences in levels of chlorinated and brominated pollutants in mother's milk from primiparous women in Sweden. Environ Int 37:71-79. doi:10.1016/j.envint.2010.07.003

Grandjean P et al (1995) Relation of a seafood diet to mercury, selenium, arsenic, and polychlorinated biphenyl and other organochlorine concentrations in human milk. Environ Res 71:29-38

Greizerstein HB, Stinson C, Mendola P, Buck GM, Kostyniak PJ, Vena JE (1999) Comparison of PCB congeners and pesticide levels between serum and milk from lactating women. Environ Res 80:280 286

GSPI (2013) Flame retardants in furniture. Green Science Policy Institute, http://greensciencepolicy.org/topics/furniture/. Accessed 141222 2014

Guvenius DM, Aronsson A, Ekman-Ordeberg G, Bergman A, Norén K (2003) Human prenatal and postnatal exposure to polybrominated diphenyl ethers, polychlorinated biphenyls, polychlorobiphenylols, and pentachlorophenol. Environ Health Perspect 111:1235-1241. doi:10.1289/ehp.5946

Haraguchi K et al (2009) Levels and regional trends of persistent organochlorines and polybrominated diphenyl ethers in Asian breast milk demonstrate POPs signatures unique to individual countries. Environ Int 35:1072-1079. doi:10.1016/j.envint.2009.06.003

Harden FA, Toms LML, Symons R, Furst P, Berry Y, Muller JF (2007) Evaluation of dioxin-like chemicals in pooled human milk samples collected in Australia. Chemosphere 67:S325-S333. doi:10.1016/j. chemosphere.2006.05.126

Harris CA, O'Hagan S, Merson GHJ (1999) Organochlorine pesticide residues in human milk in the United Kingdom 1997-8. Hum Exp Toxicol 18:602-606

Hedley AJ, Wong TW, Hui LL, Malisch R, Nelson EAS (2006) Breast milk dioxins in Hong Kong and pearl River Delta. Environ Health Perspect 114:202-208. doi:10.1289/ehp.8116

Hedley AJ et al (2010) Residues of persistent organic pollutants (POPs) in human milk in Hong Kong. Chemosphere 79:259-265. doi:10. 1016/j.chemosphere.2010.01.047

Hoaglin DC, Welsch RE (1978) The hat matrix in regression and ANOVA. Am Stat 32:17-22

Hooper K et al (1997) Analysis of breast milk to assess exposure to chlorinated contaminants in Kazakhstan: PCBs and organochlorine pesticides in southern Kazakhstan. Environ Health Perspect 105: $1250-1254$

Hooper K et al (1998) Analysis of breast milk to assess exposure to chlorinated contaminants in Kazakhstan: high levels of 2,3,7,8tetrachlorodibenzo-p-dioxin (TCDD) in agricultural villages of southern Kazakhstan. Environ Health Perspect 106:797-806
Hovander L et al (2006) Levels of PCBs and their metabolites in the serum of residents of a highly contaminated area in eastern Slovakia. Environ Sci Technol 40:3696-3703. doi:10.1021/ es0525657

Hsu JF, Guo YL, Liu CH, Hu SC, Wang JN, Liao PC (2007) A comparison of PCDD/PCDFs exposure in infants via formula milk or breast milk feeding. Chemosphere 66:311-319. doi:10.1016/j. chemosphere.2006.04.089

IPCS (1984a) Chlordane - environmental health criteria 34. Geneva

IPCS (1984b) Endosulfan - environmental health criteria 40. Geneva, Switzerland

IPCS (1984c) Heptachlor - environmental health criteria 38. Geneva

IPCS (1989a) Aldrin and dieldrin — environmental health criteria 91. Geneva

IPCS (1989b) DDT and its derivatives: environmental aspects - environmental health criteria 83 . Geneva, Switzerland

IPCS (1997) Hexachlorobenzene-environment health criteria 195. Geneva, Switzerland

IPCS (2002) Polychlorinated dibenzodioxins, polychlorinated dibenzofurans, and coplanar polychlorinated biphenyls. Geneva, Switzerland

IPCS (2007) Principles for evaluating health risks in children associated with exposure to chemicals. Geneva, Switzerland. doi: ISBN13: 9789241572378

IPCS (2011) DDT in indoor residual spraying: human health aspectsenvironmental health criteria 241. Geneva, Switzerland. doi: ISBN: 9789241572415

Jaraczewska K, Lulek J, Covaci A, Voorspoels S, Kaluba-Skotarczak A, Drews K, Schepens P (2006) Distribution of polychlorinated biphenyls, organochlorine pesticides and polybrominated diphenyl ethers in human umbilical cord serum, maternal serum and milk from Wielkopolska region. Pol Sci Total Environ 372:20-31. doi:10. 1016/j.scitotenv.2006.03.030

Johnson-Restrepo B, Addink R, Wong C, Arcaro K, Kannan K (2007) Polybrominated diphenyl ethers and organochlorine pesticides in human breast milk from Massachusetts, USA. J Environ Monit 9: 1205-1212. doi:10.1039/b711409p

Kakimoto K, Akutsu K, Konishi Y, Tanaka Y (2008) Time trend of hexabromocyclododecane in the breast milk of Japanese women. Chemosphere 71:1110-1114. doi:10.1016/j.chemosphere. 2007.10.035

Kalantzi OI et al (2004) Different levels of polybrominated diphenyl ethers (PBDEs) and chlorinated compounds in breast milk from two UK regions. Environ Health Perspect 112:1085-1091

Kärrman A, Ericson I, van Bavel B, Lindström G (2006) Mätningar av PFOS i bröstmjölk och blod. MTM, Forskningscentrum, Örebro

Kärrman A et al (2007) Exposure of perfluorinated chemicals through lactation: levels of matched human milk and serum and a temporal trend, 1996-2004, in Sweden. Environ Health Perspect 115:226 230. doi:10.1289/ehp. 9491

Kärrman A, Domingo JL, Llebaria X, Nadal M, Bigas E, van Bavel B, Lindström G (2010) Biomonitoring perfluorinated compounds in Catalonia, Spain: concentrations and trends in human liver and milk samples. Environ Sci Pollut Res 17:750-758. doi:10.1007/s11356009-0178-5

Kawashiro Y et al (2008) Perinatal exposure to brominated flame retardants and polychlorinated biphenyls in Japan. Endocr J 55:10711084

Kazda R, Hajslova J, Poustka J, Cajka T (2004) Determination of polybrominated diphenyl ethers in human milk samples in the Czech Republic - comparative study of negative chemical ionisation mass spectrometry and time-of-flight high-resolution mass spectrometry. Anal Chim Acta 520:237-243. doi:10.1016/j. aca.2004.04.069

Khanjani N, Sim MR (2006) Reproductive outcomes of maternal contamination with cyclodiene insecticides, hexachlorobenzene and beta-benzene hexachloride. Sci Total Environ 368:557-564 
Kim SK et al (2011a) Distribution of perfluorochemicals between sera and milk from the same mothers and implications for prenatal and postnatal exposures. Environ Pollut 159:169-174. doi:10.1016/j. envpol.2010.09.008

Kim UJ, Lee IS, Kim HS, Oh JE (2011b) Monitoring of PBDEs concentration in umbilical cord blood and breast milk from Korean population and estimating the effects of various parameters on accumulation in humans. Chemosphere 85:487-493. doi:10.1016/j. chemosphere.2011.08.008

Koh TW, Chen SCC, Chang-Chien GP, Lin DY, Chen FA, Chao HR (2010) Breast-milk levels of polybrominated diphenyl ether flame retardants in relation to women's age and pre-pregnant body mass index. Int J Hyg Environ Health 213:59-65. doi:10.1016/j.ijheh. 2009.09.004

Konishi Y, Kuwabara K, Hori S (2001) Continuous surveillance of organochlorine compounds in human breast milk from 1972 to 1998 in Osaka, Japan. Arch Environ Contam Toxicol 40:571-578

Kostyniak PJ, Stinson C, Greizerstein HB, Vena J, Buck G, Mendola P (1999) Relation of Lake Ontario fish consumption, lifetime lactation, and parity to breast milk polychlorobiphenyl and pesticide concentrations. Environ Res 80:S166-S174

Kozul D, Romanic SH (2010) Levels and distribution of PCBs and organochlorine pesticides in the air, pine needles, and human milk. Arh Hig Rada Toksikol 61:339-356

Kramer MS, Kakuma R (2012) Optimal duration of exclusive breastfeeding. Cochrane Database Syst Rev 132. doi:10.1002/ 14651858.CD003517.pub2

Krauthacker B, Reiner E, Votava-Raic A, Tjesic-Drinkovic D, Batinic D (1998) Organochlorine pesticides and PCBs in human milk collected from mothers nursing hospitalized children. Chemosphere 37: $27-32$

Krauthacker B, Votava-Raic A, Romanic SH, Tjesic-Drinkovic D, Reiner E (2009) Persistent organochlorine compounds in human milk collected in Croatia over two decades. Arch Environ Contam Toxicol 57:616-622

Kumar A, Dayal P, Shukla G, Singh G, Joseph PE (2006) DDT and HCH residue load in mother's breast milk: a survey of lactating mother's from remote villages in Agra region. Environ Int 32:248-251. doi: 10.1016/j.envint.2005.08.019

Kunisue T, Someya M, Kayama F, Jin Y, Tanabe S (2004a) Persistent organochlorines in human breast milk collected from primiparae in Dalian and Shenyang, China. Environ Pollut 131:381-392. doi:10. 1016/j.envpol.2004.03.008

Kunisue T, Someya M, Monirith I, Watanabe M, Tana TS, Tanabe S (2004b) Occurrence of PCBs, organochlorine insecticides, tris(4chlorophenyl)methane, and tris(4-chlorophenyl)methanol in human breast milk collected from Cambodia. Arch Environ Contam Toxicol 46:405-412. doi:10.1007/s00244-003-3008-7

Kunisue T et al (2006) Contamination status of persistent organochlorines in human breast milk from Japan: recent levels and temporal trend. Chemosphere 64:1601-1608. doi:10.1016/j.chemosphere.2005.11. 010

Lankova D, Lacina O, Pulkrabova J, Hajslova J (2013) The determination of perfluoroalkyl substances, brominated flame retardants and their metabolites in human breast milk and infant formula. Talanta 117: 318-325. doi:10.1016/j.talanta.2013.08.040

Leng JH, Kayama F, Wang PY, Nakamura M, Nakata T, Wang Y (2009) Levels of persistent organic pollutants in human milk in two Chinese coastal cities, Tianjin and Yantai: influence of fish consumption. Chemosphere 75:634-639. doi:10.1016/j.chemosphere.2009.01. 008

Li JG et al (2009) A national survey of polychlorinated dioxins, furans (PCDD/Fs) and dioxin-like polychlorinated biphenyls (dl-PCBs) in human milk in China. Chemosphere 75:1236-1242. doi:10.1016/j. chemosphere.2009.01.073
Lignell S, Darnerud PO, Aune M, Törnkvist A (2003) Persistent organic pollutants (POP) in breastmilk from primiparae women in Uppsala County, Sweden, 2002-2003. Livsmedelsverket, Stockholm

Lignell S, Darnerud PO, Aune M, Törnkvist A, Glynn A (2004) Bifenyler och klorerade bekämpningsmeled/metaboliter i bröstmjölk från förstföderskor i Uppsala, tidstrend 1996-2003. Livsmedelsverket, Uppsala

Lignell S, Aune M, Darnerud PO, Cnattingius S, Glynn A (2009a) Persistent organochlorine and organobromine compounds in mother's milk from Sweden 1996-2006: compound-specific temporal trends. Environ Res 109:760-767. doi:10.1016/j.envres.2009.04. 011

Lignell S, Glynn A, Törnkvist A, Aune M, Darnerud PO (2009b) Persistenta halogenerade organiska miljöföroreningar i modersmjölk från förstföderskor i Uppsala 2008. Livsmedelsverket, Stockholm

Lignell S, Aune M, Darnerud PO, Soeria-Atmadja D, Hanberg A, Larsson S, Glynn A (2011) Large variation in breast milk levels of organohalogenated compounds is dependent on mother's age, changes in body composition and exposures early in life. $\mathrm{J}$ Environ Monit 13:1607-1616. doi:10.1039/c1em10151j

Lind Y et al (2003) Polybrominated diphenyl ethers in breast milk from Uppsala County, Sweden. Environ Res 93:186-194. doi:10.1016/ s0013-9351(03)00049-5

Lindström AB, Strynar MJ, Libelo EL (2011) Polyfluorinated compounds: past, present, and future. Environ Sci Technol 45:7954 7961. doi:10.1021/es2011622

Liu JY, Li JG, Zhao YF, Wang YX, Zhang L, Wu YN (2010) The occurrence of perfluorinated alkyl compounds in human milk from different regions of China. Environ Int 36:433-438. doi:10.1016/j. envint.2010.03.004

Llorca M, Farre M, Pico Y, Teijon ML, Alvarez JG, Barcelo D (2010) Infant exposure of perfluorinated compounds: levels in breast milk and commercial baby food. Environ Int 36:584-592. doi:10.1016/j. envint.2010.04.016

Lundén A, Norén K (1998) Polychlorinated naphthalenes and other organochlorine contaminants in Swedish human milk, 1972-1992. Arch Environ Contam Toxicol 34:414-423

Lutter C, Iyengar V, Barnes R, Chuvakova T, Kazbekova G, Sharmanov $\mathrm{T}$ (1998) Breast milk contamination in Kazakhstan: implications for infant feeding. Chemosphere 37:1761-1772

Madden AB, Makarewicz JC (1996) Salmonine consumption as a source of mirex in human breast milk near Rochester, New York. J Great Lakes Res 22:810-817

Malarvannan G et al (2009) Organohalogen compounds in human breast milk from mothers living in Payatas and Malate, the Philippines: levels, accumulation kinetics and infant health risk. Environ Pollut 157:1924-1932. doi:10.1016/j.envpol.2009.01.010

Manaca MN et al (2011) Concentration of DDT compounds in breast milk from African women (Manhica, Mozambique) at the early stages of domestic indoor spraying with this insecticide. Chemosphere 85:307-314. doi:10.1016/j.chemosphere.2011.06. 015

Meironyté D, Norén K, Bergman A (1999) Analysis of polybrominated diphenyl ethers in Swedish human milk. A time-related trend study, 1972-1997. J Toxicol Environ Health A 58:329-341. doi:10.1080/ 009841099157197

Minh NH et al (2004) Persistent organochlorine residues in human breast milk from Hanoi and Hochiminh city, Vietnam: contamination, accumulation kinetics and risk assessment for infants. Environ Pollut 129:431-441. doi:10.1016/j.envpol.2003.11.012

Mishra K, Sharma RC (2011) Assessment of organochlorine pesticides in human milk and risk exposure to infants from North-East India. Sci Total Environ 409:4939-4949. doi:10.1016/j.scitotenv.2011.07.038

Miyake Y, Tanaka K, Masuzaki Y, Sato N, Ikeda Y, Chisaki Y, Arakawa M (2011) Organochlorine concentrations in breast milk and 
prevalence of allergic disorders in Japanese women. Chemosphere 85:374-378. doi:10.1016/j.chemosphere.2011.07.001

Mueller JF, Harden F, Toms LM, Symons R, Furst P (2008) Persistent organochlorine pesticides in human milk samples from Australia. Chemosphere 70:712-720. doi:10.1016/j.chemosphere.2007.06. 037

Nagayama J, Kohno H, Kunisue T, Kataoka K, Shimomura H, Tanabe S, Konishi S (2007a) Concentrations of organochlorine pollutants in mothers who gave birth to neonates with congenital hypothyroidism. Chemosphere 68:972-976. doi:10.1016/j.chemosphere.2007. 01.010

Nagayama $J$ et al (2007b) Immunologic effects of perinatal exposure to dioxins, PCBs and organochlorine pesticides in Japanese infants. Chemosphere 67:S393-S398. doi:10.1016/j.chemosphere.2006.05. 134

Nair A, Mandapati R, Dureja P, Pillai MKK (1996) DDT and HCH load in mothers and their infants in Delhi, India. Bull Environ Contam Toxicol 56:58-64

Nakamura T, Nakai K, Matsumura T, Suzuki S, Saito Y, Satoh H (2008) Determination of dioxins and polychlorinated biphenyls in breast milk, maternal blood and cord blood from residents of Tohoku, Japan. Sci Total Environ 394:39-51. doi:10.1016/j.scitotenv.2008. 01.012

Nasir K, Bilto YY, Al-Shuraiki Y (1998) Residues of chlorinated hydrocarbon insecticides in human milk of Jordanian women. Environ Pollut 99:141-148

Newsome WH, Ryan JJ (1999) Toxaphene and other chlorinated compounds in human milk from northern and southern Canada: a comparison. Chemosphere 39:519-526

Newsome WH, Davies D, Doucet J (1995) PCB and organochlorine pesticides in Canadian human-milk-1992. Chemosphere 30: 2143-2153

Nguyen MT et al (2010) Kinetic differences of legacy organochlorine pesticides and polychlorinated biphenyls in Vietnamese human breast milk. Chemosphere 81:1006-1011

Nhu DD et al (2011) Dioxin levels in the breast milk and estradiol and androgen levels in the saliva of Vietnamese primiparae. Toxicol Environ Chem 93:824-838. doi:10.1080/02772248.2011.552226

Nicholson M, Fryer R, Larsen J (1998) Temporal trend monitoring: A robust method for analysing contaminant trend monitoring data. ICES techniques in marine environmental sciences No. 20. ICES. ISSN 0903-2606.

NICNAS (2004) Environmental exposure assessment of short chain chlorinated paraffins (SCCPs) in Australia. Australia

Noakes PS, Taylor P, Wilkinson S, Prescott SL (2006) The relationship between persistent organic pollutants in maternal and neonatal tissues and immune responses to allergens: a novel exploratory study. Chemosphere 63:1304-1311. doi:10.1016/j.chemosphere.2005.09. 008

Norén K, Meironyte D (2000) Certain organochlorine and organobromine contaminants in Swedish human milk in perspective of past 20-30 years. Chemosphere 40:1111-1123

Norén K, Westöö G (1968) Determination of some chlorinated pesticides in vegetable oils margarine butter milk eggs meat and fish by gas chromatography and thin-layer chromatography. Acta Chem Scand 22:2289. doi:10.3891/acta.chem.scand.22-2289

Norén K, Lundén A, Pettersson E, Bergman A (1996) Methylsulfonyl metabolites of PCBs and DDE in human milk in Sweden, 19721992. Environ Health Perspect 104:766-772

Ntow WJ (2001) Organochlorine pesticides in water, sediment, crops, and human fluids in a farming community in Ghana. Arch Environ Contam Toxicol 40:557-563

Ntow WJ, Tagoe LM, Drechsel P, Kelderman P, Gijzen FJ, Nyarko E (2008) Accumulation of persistent organochlorine contaminants in milk and serum of farmers from Ghana. Environ Res 106:17-26. doi:10.1016/j.envres.2007.05.020
Nyberg E et al. (2011) The National Swedish Contaminant Monitoring Programme in fresh water biota. 14:2011. Swedish Museum of Natural History.

Okonkwo JO, Kampira L, Chingakule DDK (1999) Organochlorine insecticides residues in human milk: a study of lactating mothers in Siphofaneni, Swaziland. Bull Environ Contam Toxicol 63:243-247

Okonkwo JO, Mutshatshi TN, Botha B, Agyei N (2008) DDT, DDE and DDD in human milk from South Africa. Bull Environ Contam Toxicol 81:348-354. doi:10.1007/s00128-008-9495-5

Ozcan S, Tor A, Aydin ME (2011) Levels of organohalogenated pollutants in human milk samples from Konya City, Turkey. Clean-Soil Air Water 39:978-983. doi:10.1002/clen.201100068

Pan IJ, Daniels JL, Herring AH, Rogan WJ, Siega-Riz AM, Goldman BD, Sjodin A (2010) Lactational exposure to polychlorinated biphenyls, dichlorodiphenyltrichloroethane, and dichlorodiphenyldichloroethylene and infant growth: an analysis of the Pregnancy, Infection, and Nutrition Babies Study. Paediatr Perinat Epidemiol 24:262-271. doi:10.1111/j.1365-3016.2010. 01114.x

Pardio VT, Waliszewski SM, Aguirre AA, Coronel H, Burelo GV, Infanzon RM, Rivera J (1998) DDT and its metabolites in human milk collected in Veracruz City and suburban areas (Mexico). Bull Environ Contam Toxicol 60:852-857

Park JS et al (2011) High postnatal exposures to polybrominated diphenyl ethers (PBDEs) and polychlorinated biphenyls (PCBs) via breast milk in California: does BDE-209 transfer to breast milk? Environ Sci Technol 45:4579-4585. doi:10.1021/es103881n

Paumgartten FJR, Cruz CM, Chahoud I, Palavinskas R, Mathar W (2000) PCDDs, PCDFs, PCBs, and other organochlorine compounds in human milk from Rio de Janeiro, Brazil. Environ Res 83:293-297

Petrik J, Drobna B, Kocan A, Chovancova J, Pavuk M (2001) Polychlorinated biphenyls in human milk from Slovak mothers. Fresenius Environ Bull 10:342-348

Pico Y, Viana E, Font G, Manes J (1995) Determination of organochlorine pesticide content in human-milk and infant formulas using solid-phase extraction and capillary gas-chromatography. J Agric Food Chem 43:1610-1615

Pietrzak-Fiecko R, Smoczynska K, Smoczynski SS (2005) Polychlorinated biphenyls in human milk, UHT cow's milk and infant formulas. Pol J Environ Stud 14:237-241

Polder A, Becher G, Savinova TN, Skaare JU (1998) Dioxins, PCBs and some chlorinated pesticides in human milk from the Kola Peninsula, Russia. Chemosphere 37:1795-1806

Polder A, Gabrielsen GW, Odland JO, Savinova TN, Tkachev A, Loken $\mathrm{KB}$, Skaare JU (2008a) Spatial and temporal changes of chlorinated pesticides, PCBs, dioxins (PCDDs/PCDFs) and brominated flame retardants in human breast milk from Northern Russia. Sci Total Environ 391:41-54. doi:10.1016/j.scitotenv.2007.10.045

Polder A, Thomsen C, Lindstrom G, Loken KB, Skaare JU (2008b) Levels and temporal trends of chlorinated pesticides, polychlorinated biphenyls and brominated flame retardants in individual human breast milk samples from Northern and Southern Norway. Chemosphere 73:14-23. doi:10.1016/j.chemosphere. 2008.06.002

Polder A, Skaare JU, Skjerve E, Loken KB, Eggesbo M (2009) Levels of chlorinated pesticides and polychlorinated biphenyls in Norwegian breast milk (2002-2006), and factors that may predict the level of contamination. Sci Total Environ 407:4584-4590. doi:10.1016/j. scitotenv.2009.04.032

Poon BHT, Leung CKM, Wong CKC, Wong MH (2005) Polychlorinated biphenyls and organochlorine pesticides in human adipose tissue and breast milk collected in Hong Kong. Arch Environ Contam Toxicol 49:274-282. doi:10.1007/s00244-004-0111-3

Qu WY, Suri RPS, Bi XH, Sheng GY, Fu JM (2010) Exposure of young mothers and newborns to organochlorine pesticides (OCPs) in 
Guangzhou, China. Sci Total Environ 408:3133-3138. doi:10.1016/ j.scitotenv.2010.04.023

Quinsey PM, Donohue DC, Ahokas JT (1995) Persistence of organochlorines in breast-milk of women in Victoria, Australia. Food Chem Toxicol 33:49-56

Raab U, Preiss U, Albrecht M, Shahin N, Parlar H, Fromme H (2008) Concentrations of polybrominated diphenyl ethers, organochlorine compounds and nitro musks in mother's milk from Germany (Bavaria). Chemosphere 72:87-94. doi:10.1016/j.chemosphere. 2008.01.053

Ribas-Fito NR, Grimalt JO, Marco E, Sala M, Mazon C, Sunyer J (2005) Breastfeeding and concentrations of HCB and p, $\mathrm{p}^{\prime}-\mathrm{DDE}$ at the age of 1 year. Environ Res 98:8-13. doi:10.1016/j.envres.2004.05.017

Riva E, Grandi F, Massetto N, Radaelli G, Giovannini M, Zetterstrom R, Agostoni C (2004) Polychlorinated biphenyls in colostral milk and visual function at 12 months of life. Acta Paediatr 93:1103-1107. doi:10.1080/08035250410014890

Rodas-Ortiz JP, Ceja-Moreno V, Gonzalez-Navarrete RL, AlvaradoMejia J, Rodriguez-Hernandez ME, Gold-Bouchot G (2008) Organochlorine pesticides and polychlorinated biphenyls levels in human milk from Chelem, Yucatan, Mexico. Bull Environ Contam Toxicol 80:255-259. doi:10.1007/s00128-007-9356-7

Romanic SH, Krauthacker B (2006) Organochlorine pesticides and PCB congeners in human milk from two population groups in Croatia. Bull Environ Contam Toxicol 76:705-711

Romero MLL, Dorea JG, Granja ACC (2000) Concentrations of organochlorine pesticides in milk of Nicaraguan mothers. Arch Environ Health 55:274-278

Saeed T, Sawaya WN, Ahmad N, Rajagopal S, Dashti B, Al-Awadhi S (2000) Assessment of the levels of chlorinated pesticides in breast milk in Kuwait. Food Addit Contam 17:1013-1018

Saito K et al (2005) Systematic analysis and overall toxicity evaluation of dioxins and hexachlorobenzene in human milk. Chemosphere 61: 1215-1220. doi:10.1016/j.chemosphere.2005.04.035

Saleh M, Kamel A, Ragab A, ElBaroty G, ElSebae AK (1996) Regional distribution of organochlorine insecticide residues in human milk from Egypt. J Environ Sci Health Part B Pestic Contam Agric Wastes 31:241-255

Sanghi R, Pillai MKK, Jayalekshmi TR, Nair A (2003) Organochlorine and organophosphorus pesticide residues in breast milk from Bhopal, Madhya Pradesh, India. Hum Exp Toxicol 22:73-76. doi: 10.1191/0960327103ht321oa

SCa What are POPs? The Stockholm Convention. http://chm.pops.int/ TheConvention/ThePOPs/tabid/673/Default.aspx

$\mathrm{SCb}$ Chemicals proposed for listing under the Convention. The Stockholm Convention. http://chm.pops.int/TheConvention/ ThePOPs/ChemicalsProposedforListing/tabid/2510/Default.aspx. Accessed 30 Apr 2014

Schade G, Heinzow B (1998) Organochlorine pesticides and polychlorinated biphenyls in human milk of mothers living in Northern Germany: current extent of contamination, time trend from 1986 to 1997 and factors that influence the levels of contamination. Sci Total Environ 215:31-39

Schecter A et al (2002) Levels of dioxins and dibenzofurans in breast milk of women residing in two cities in the Irkutsk region of Russian Siberia compared with American levels. Chemosphere 47:157-164

Schecter A, Pavuk M, Päpke O, Ryan JJ, Birnbaum L, Rosen R (2003) Polybrominated diphenyl ethers (PBDEs) in US mothers' milk. Environ Health Perspect 111:1723-1729. doi:10.1289/ehp.6466

Schecter A, Päpke O, Tung KC, Joseph J, Harris TR, Dahlgren J (2005) Polybrominated diphenyl ether flame retardants in the US population: current levels, temporal trends, and comparison with dioxins, dibenzofurans, and polychlorinated biphenyls. J Occup Environ Med 47:199-211. doi:10.1097/01.jom.0000158704.27536.d2

Schecter A, Colacino J, Sjödin A, Needham L, Birnbaum L (2010) Partitioning of polybrominated diphenyl ethers (PBDEs) in serum and milk from the same mothers. Chemosphere 78:1279-1284. doi: 10.1016/j.chemosphere.2009.12.016

Schinas V, Leotsinidis M, Alexopoulos A, Tsapanos V, Kondakis XG (2000) Organochlorine pesticide residues in human breast milk from southwest Greece: associations with weekly food consumption patterns of mothers. Arch Environ Health 55:411-417

Schlaud M et al (1995) Organochlorine residues in human breast-milkanalysis through a sentinel practice network. J Epidemiol Community Health 49:17-21

Schoula R, Hajslova J, Bencko V, Poustka J, Holadova K, Vizek V (1996) Occurrence of persistent organochlorine contaminants in human milk collected in several regions of Czech Republic. Chemosphere 33:1485-1494

Schuhmacher M, Domingo JL, Kiviranta H, Vartiainen T (2004) Monitoring dioxins and furans in a population living near a hazardous waste incinerator: levels in breast milk. Chemosphere 57:43-49. doi:10.1016/j.chemosphere.2004.05.007

Schuhmacher M, Kiviranta H, Ruokojarvi P, Nadal M, Domingo JL (2009) Concentrations of PCDD/Fs, PCBs and PBDEs in breast milk of women from Catalonia, Spain: a follow-up study. Environ Int 35:607-613. doi:10.1016/j.envint.2008.12. 003

Sereda B, Bouwman H, Kylin H (2009) Comparing water, bovine milk, and indoor residual spraying as possible sources of DDT and pyrethroid residues in breast milk. J Toxicol Environ Health A 72:897908. doi:10.1080/15287390902959565

She J et al (1998) Congener-specific analysis of PCBs in human milk from Kazakhstan. Chemosphere 37:431-442

Shen HQ et al (2007) From mother to child: investigation of prenatal and postnatal exposure to persistent bioaccumulating toxicants using breast milk and placenta biomonitoring. Chemosphere 67:S256 S262. doi:10.1016/j.chemosphere.2006.05.106

Shen $\mathrm{H}$ et al (2008) Concentrations of persistent organochlorine compounds in human milk and placenta are higher in Denmark than in Finland. Hum Reprod 23:201-210. doi:10.1093/humrep/dem199

Shi ZX, Wu YN, Li JG, Zhao YF, Feng JF (2009) Dietary exposure assessment of Chinese adults and nursing infants to tetrabromobisphenol-A and hexabromocyclododecanes: occurrence measurements in foods and human milk. Environ Sci Technol 43: 4314 4319. doi:10.1021/es8035626

Siddiqui MKJ, Nigam U, Srivastava S, Tejeshwar DS, Chandrawati (2002) Association of maternal blood pressure and hemoglobin level with organochlorines in human milk. Hum Exp Toxicol 21:1-6

Sim M, Forbes A, McNeil J, Roberts G (1998) Termite control and other determinants of high body burdens of cyclodiene insecticides. Arch Environ Health 53:114-121

Skopp S, Oehme M, Furst P (2002) Enantiomer ratios, patterns and levels of toxaphene congeners in human milk from Germany. J Environ Monit 4:389-394. doi:10.1039/b200133k

Skrbic B, Szyrwinska K, Durisic-Mladenovic N, Nowicki P, Lulek J (2010) Principal component analysis of indicator PCB profiles in breast milk from Poland. Environ Int 36:862-872

So MK, Yamashita N, Taniyasu S, Jiang QT, Giesy JP, Chen K, Lam PKS (2006) Health risks in infants associated with exposure to perfluorinated compounds in human breast milk from Zhoushan, China. Environ Sci Technol 40:2924-2929. doi:10.1021/es060031f

State of California (2000) Technical bulletin 117. State of California, CA, USA

State of California (2013) Technical bulletin 177-2013. State of California, CA, USA

Stemmler I, Lammel G (2009) Cycling of DDT in the global environment 1950-2002: world ocean returns the pollutant. Geophys Res Lett 36. doi: $10.1029 / 2009 \mathrm{gl} 041340$ 
Stock NL, Muir DCG, Mabury S (2009) Perfluoroalkyl compounds. In: Harrad S (ed) Persistent organic pollutants. Wiley, Chichester. doi: 10.1002/9780470684122.ch3

Stuetz W, Prapamontol T, Erhardt JG, Classen HG (2001) Organochlorine pesticide residues in human milk of a Hmong hill tribe living in Northern Thailand. Sci Total Environ 273:53-60

Sudaryanto A, Kunisue T, Tanabe S, Niida M, Hashim H (2005) Persistent organochlorine compounds in human breast milk from mothers living in Penang and Kedah, Malaysia. Arch Environ Contam Toxicol 49:429-437. doi:10.1007/s00244-004-0208-8

Sudaryanto A, Kunisue T, Kajiwara N, Iwata H, Adibroto TA, Hartono P, Tanabe S (2006) Specific accumulation of organochlorines in human breast milk from Indonesia: levels, distribution, accumulation kinetics and infant health risk. Environ Pollut 139:107-117. doi:10. 1016/j.envpol.2005.04.028

Sudaryanto A, Kajiwara N, Takahashi S, Muawanah, Tanabe S (2008a) Geographical distribution and accumulation features of PBDEs in human breast milk from Indonesia. Environ Pollut 151:130-138. doi:10.1016/j.envpol.2007.02.016

Sudaryanto A, Kajiwara N, Tsydenova OV, Isobe T, Yu HX, Takahashi S, Tanabe $\mathrm{S}$ (2008b) Levels and congener specific profiles of PBDEs in human breast milk from China: implication on exposure sources and pathways. Chemosphere 73:1661-1668. doi:10.1016/j. chemosphere.2008.07.088

Sun SJ et al (2005) Persistent organic pollutants in human milk in women from urban and rural areas in northern China. Environ Res 99:285293. doi:10.1016/j.envres.2005.05.007

Sun SJ et al (2010) Levels of dioxins and polybrominated diphenyl ethers in human milk from three regions of northern China and potential dietary risk factors. Chemosphere 80:1151-1159. doi:10.1016/j. chemosphere.2010.06.021

Sun SJ et al (2011) Longitudinal increases in PCDD/F and dl-PCB concentrations in human milk in northern China. Chemosphere 85:448453. doi:10.1016/j.chemosphere.2011.07.073

Sundström M, Ehresman DJ, Bignert A, Butenhoff JL, Olsen GW, Chang SC, Bergman $\AA$ (2011) A temporal trend study (19722008) of perfluorooctanesulfonate, perfluorohexanesulfonate, and perfluorooctanoate in pooled human milk samples from Stockholm, Sweden. Environ Int 37:178-183. doi:10.1016/j. envint.2010.08.014

Suzuki G, Nakano M, Nakano S (2005) Distribution of PCDDs/PCDFs and co-PCBs in human maternal blood, cord blood, placenta, milk, and adipose tissue: dioxins showing high toxic equivalency factor accumulate in the placenta. Biosci Biotechnol Biochem 69:18361847

Tajimi M, Uehara R, Watanabe M, Oki I, Ojima T, Nakamura Y (2005) Correlation coefficients between the dioxin levels in mother's milk and the distances to the nearest waste incinerator which was the largest source of dioxins from each mother's place of residence in Tokyo, Japan. Chemosphere 61:1256-1262. doi:10.1016/j. chemosphere.2005.03.096

Tao L, Kannan K, Wong CM, Arcaro KF, Butenhoff JL (2008a) Perfluorinated compounds in human milk from Massachusetts, USA. Environ Sci Technol 42:3096-3101. doi:10.1021/es702789k

Tao S et al (2008b) Validation of dietary intake of dichlorodiphenyltrichloroethane and metabolites in two populations from Beijing and Shenyang, China based on the residuals in human milk. Environ Sci Technol 42:7709-7714. doi:10.1021/es801219v

Tawara K et al (2011) Residual congener pattern of dioxins in human breast milk in southern Vietnam. Chemosphere 84:979-986. doi:10. 1016/j.chemosphere.2011.05.041

Thomas GO, Farrar D, Braekevelt E, Stern G, Kalantzi OI, Martin FL, Jones KC (2006) Short and medium chain length chlorinated paraffins in UK human milk fat. Environ Int 32:34-40

Thomsen C, Stigum H, Froshaug M, Broadwell SL, Becher G, Eggesbo M (2010) Determinants of brominated flame retardants in breast milk from a large scale Norwegian study. Environ Int 36:68-74. doi:10.1016/j.envint.2009.10.002

Thuresson K, Höglund P, Hagmar L, Sjödin A, Bergman Å, Jakobsson K (2006) Apparent half-lives of hepta- to decabrominated diphenyl ethers in human serum as determined in occupationally exposed workers. Environ Health Perspect 114:176-181. doi:10.1289/ehp. 8350

Todaka T et al (2011) Concentrations of polychlorinated dibenzo-p-dioxins, polychlorinated dibenzofurans, and polychlorinated biphenyls in blood and breast milk collected from pregnant women in Sapporo City, Japan. Chemosphere 85:1694-1700. doi:10.1016/j. chemosphere.2011.09.014

Torres-Arreola L, Lopez-Carrillo L, Torres-Sanchez L, Cebrian M, Rueda C, Reyes R, Lopez-Cervantes M (1999) Levels of dichlorodyphenyl-trichloroethane (DDT) metabolites in maternal milk and their determinant factors. Arch Environ Health 54:124-129

Tsang HL, Wu SC, Wong CKC, Leung CKM, Tao S, Wong MH (2009) Risk assessment of PCDD/Fs levels in human tissues related to major food items based on chemical analyses and micro-EROD assay. Environ Int 35:1040-1047. doi:10.1016/j.envint.2009.05.005

Tsang HL, Wu SC, Leung CKM, Tao S, Wong MH (2011) Body burden of POPs of Hong Kong residents, based on human milk, maternal and cord serum. Environ Int 37:142-151. doi:10.1016/j.envint. 2010.08.010

Tsydenova OV, Sudaryanto A, Kajiwara N, Kunisue T, Batoev VB, Tanabe S (2007) Organohalogen compounds in human breast milk from Republic of Buryatia, Russia. Environ Pollut 146:225-232

Tue NM, Sudaryanto A, Tu BM, Isobe T, Takahashi S, Pham HV, Tanabe S (2010) Accumulation of polychlorinated biphenyls and brominated flame retardants in breast milk from women living in Vietnamese e-waste recycling sites. Sci Total Environ 408:2155-2162. doi:10. 1016/j.scitotenv.2010.01.012

Ulaszewska MM et al (2011) The effect of waste combustion on the occurrence of polychlorinated dibenzo-p-dioxins (PCDDs), polychlorinated dibenzofurans (PCDFs) and polychlorinated biphenyls (PCBs) in breast milk in Italy. Chemosphere 82:1-8. doi:10. 1016/j.chemosphere.2010.10.044

UNEP (2004) Guidance for a global monitoring programme for persistent organic pollutants, 1 st edn. UNEP

UNEP (2009) Status report on the human milk survey conducted jointly by the Secretariat of the Stockholm Convention and the World Health Organization. Geneva

UNEP (2011) Regional monitoring reports under the global monitoring plan for effectiveness evaluation: additional tissue data from the human milk survey. Geneva

UNEP, WHO (2013) State of the science of endocrine disrupting chemicals - 2012. WHO-UNEP, Geneva

van den Berg M, Sinnige TL, Tysklind M, Bosveld ATC, Huisman M, KoopmansEssenboom C, Koppe JG (1995) Individual PCBs as predictors for concentrations of non and mono-ortho PCBs in human milk. Environ Sci Pollut Res 2:73-82

Van den Berg M et al (1998) Toxic equivalency factors (TEFs) for PCBs, PCDDs, PCDFs for humans and wildlife. Environ Health Perspect 106:775-792. doi:10.1289/ehp.98106775

Van den Berg M et al (2006) The 2005 World Health Organization reevaluation of human and mammalian toxic equivalency factors for dioxins and dioxin-like compounds. Toxicol Sci 93:223-241. doi: 10.1093/toxsci/kfl055

Vartiainen T, Saarikoski S, Jaakkola JJ, Tuomisto J (1997) PCDD, PCDF, and PCB concentrations in human milk from two areas in Finland. Chemosphere 34:2571-2583

Veningerova M, Prachar V, Uhnak J, Kovacicova J (2001) Levels of persistent organochlorine compounds in human milk from several regions of Slovak republic. Fresenius Environ Bull 10:701-705

Vijgen J et al (2011) Hexachlorocyclohexane $(\mathrm{HCH})$ as new Stockholm Convention POPs - a global perspective on the management of 
Lindane and its waste isomers. Environ Sci Pollut Res 18:152-162. doi:10.1007/s11356-010-0417-9

Volkel W et al (2008) Perfluorooctane sulphonate (PFOS) and perfluorooctanoic acid (PFOA) in human breast milk: results of a pilot study. Int J Hyg Environ Health 211:440-446. doi:10.1016/j. ijheh.2007.07.024

Vukavic T, Vojinovic-Miloradov M, Pavkov S, Djilas S (2003) Pesticide residues and polychlorinated biphenyls in human colostrum - seasonal variations in Yugoslavia a decade later. Fresenius Environ Bull $12: 215-218$

Vukavic T, Miloradov MV, Ristivojevic A, Hlpka J (2008) PCB pollution of early milk in the Province of Vojvodina. Environ Toxicol Pharmacol 25:176-178

Waliszewski SM, Aguirre AA, Infanzon RM, Rivera J, Infanzon R (1998) Levels of organochlorine pesticide residues in human milk from mothers living in Veracruz, Mexico. Fresenius Environ Bull 7: 709-716

Waliszewski SM, Aguirre AA, Infanzon RM (1999a) Comparison of organochlorine pesticide residue levels in colostrum and mature milk from mothers living in Veracruz, Mexico. Fresenius Environ Bull 8:678-684

Waliszewski SM, Aguirre AA, Infanzon RM, Benitez A, Rivera J (1999b) Comparison of organochlorine pesticide levels in adipose tissue and human milk of mothers living in Veracruz, Mexico. Bull Environ Contam Toxicol 62:685-690

Wang SL, Lin CY, Guo YLL, Lin LY, Chou WL, Chang LW (2004) Infant exposure to polychlorinated dibenzo-p-dioxins, dibenzofurans and biphenyls (PCDD/Fs, $\mathrm{PCBs}$ ) - correlation between prenatal and postnatal exposure. Chemosphere 54:1459-1473. doi:10. 1016/j.chemosphere.2003.08.012

Wang DC, Yu P, Zhang Y, Cui Y, Sun CH (2008) The determination of persistent organic pollutants (POPs) in the colostrums of women in preterm labor. Clin Chim Acta 397:18-21. doi:10.1016/j.cca.2008. 07.004

Weldon RH, Barr DB, Trujillo C, Bradman A, Holland N, Eskenazi B (2011) A pilot study of pesticides and PCBs in the breast milk of women residing in urban and agricultural communities of California. J Environ Monit 13:3136-3144. doi:10.1039/c1em10469a

Westöö G, Norén K (1978) Organochlorine contaminants in human milk, Stockholm 1967-1977. Ambio 7:62-64

WHO (2009) Biomonitoring of human milk for persistent organic pollutants (POPs). http://www.who.int/foodsafety/chem/pops biomonitoring/en/. Accessed 15 May 2013

WHO, UNICEF (2014) Exclusive breastfeeding. http://www.who.int/ nutrition/topics/exclusive breastfeeding/en/

Wittsiepe J et al (2007) PCDD/F and dioxin-like PCB in human blood and milk from German mothers. Chemosphere 67:S286-S294. doi: 10.1016/j.chemosphere.2006.05.118
Wong CKC, Leung KM, Poon BHT, Lan CY, Wong MH (2002) Organochlorine hydrocarbons in human breast milk collected in Hong Kong and Guangzhou. Arch Environ Contam Toxicol 43: 364-372. doi:10.1007/s00244-002-1210-7

Xing GH, Chan JKY, Leung AOW, Wu SC, Wong MH (2009) Environmental impact and human exposure to PCBs in Guiyu, an electronic waste recycling site in China. Environ Int 35:7682

Yang YH, Chang YS, Kim BH, Shin DC, Ikonomou MG (2002) Congener-distribution patterns and risk assessment of polychlorinated biphenyls, dibenzo-p-dioxins and dibenzofurans in Korean human milk. Chemosphere 47:1087-1095

Yao Z, Zhang Y, Jiang G (2005) Residues of organochlorine compounds in human breast milk collected from Beijing, People's Republic of China. Bull Environ Contam Toxicol 74:155-161. doi:10.1007/ s00128-004-0562-2

Yu ZW, Palkovicova L, Drobna B, Petrik J, Kocan A, Trnovec T, HertzPicciotto I (2007) Comparison of organochlorine compound concentrations in colostrum and mature milk. Chemosphere 66:1012-1018

Yu WG, Liu W, Jin YH, Liu XH, Wang FQ, Liu L, Nakayama SF (2009) Prenatal and postnatal impact of perfluorooctane sulfonate (PFOS) on rat development: a cross-foster study on chemical burden and thyroid hormone system. Environ Sci Technol 43:8416-8422. doi: 10.1021/es901602d

Zehringer M, Herrmann A (2001) Analysis of polychlorinated biphenyls, pyrethroid insecticides and fragrances in human milk using a laminar cup liner in the GC injector. Eur Food Res Technol 212:247-251

Zhang L et al (2011) A national survey of polybrominated diphenyl ethers (PBDEs) and indicator polychlorinated biphenyls (PCBs) in Chinese mothers' milk. Chemosphere 84:625-633. doi:10.1016/j. chemosphere.2011.03.041

Zhao GF, Xu Y, Li W, Han GG, Ling B (2007) PCBs and OCPs in human milk and selected foods from Luqiao and Pingqiao in Zhejiang, China. Sci Total Environ 378:281-292

Zheng MH, Yang LC, Zhang B (2003) Polychlorinated dibenzo-pdioxins and dibenzofurans in breast milk from Chinese schistosomiasis areas. Bull Environ Contam Toxicol 70:189-192. doi:10.1007/ s00128-002-0175-6

Zhou PP et al (2011) National survey of the levels of persistent organochlorine pesticides in the breast milk of mothers in China. Environ Pollut 159:524-531. doi:10.1016/j.envpol.2010.10.014

Zietz BP, Hoopmann M, Funcke M, Huppmann R, Suchenwirth R, Gierden E (2008) Long-term biomonitoring of polychlorinated biphenyls and organochlorine pesticides in human milk from mothers living in northern Germany. Int J Hyg Environ Health 211:624-638. doi:10.1016/j.ijheh.2008.04.001

Zubcic S, Krauthacker B (2004) Analysis of polychlorinated biphenyl congeners in human milk collected in Zagreb, Croatia. Fresenius Environ Bull 13:346-352 